\title{
10. CRETACEOUS FORAMINIFERS FROM THE SOUTHWESTERN ATLANTIC OCEAN, LEG 36, DEEP SEA DRILLING PROJECT
}

\author{
William V. Sliter, U.S. Geological Survey, Menlo Park, California
}

\begin{abstract}
Cretaceous foraminifers were recovered from DSDP Leg 36 sites 327 and 330 on the eastern Falkland Plateau. Foraminifers from Hole 327A range in age from Albian to Maestrichtian whereas those from Holes 330 and $330 \mathrm{~A}$ are Albian and Cenomanian. Assemblages are characterized by a low-diversity planktonic fauna dominated by species of Hedbergella, Globigerinelloides, Archaeoglobigerina, Whiteinella, Heterohelix, and Rugoglobigerina. Species of Praeglobotruncana, Rotalipora, Globotruncana, and Globotruncanella generally are rare. The foraminifers are Austral in character and indicate that the depositional environments ranged from 100 to 400 meters in the Albian to 1500 to 2500 meters in the Campanian-Maestrichtian. Santonian assemblages suggest abyssal water depths greater than 2500 meters and indicate a complex midCretaceous history of tectonism and altered hydrographic conditions.

Comparison of the Cretaceous assemblages from Leg 36 with those from other localities in the southern hemisphere shows three major features. (1) Aptian-Albian faunas from the higher southern latitudes are Austral or extratropical in character. (2) The prominent mid-Cretaceous hiatus recognized in Hole $327 \mathrm{~A}$ is interregional in extent. The correspondence of this hiatus with midCretaceous events that include major changes in the tectonic evolution of the ocean basin, sea-level, and climate suggests a causal relationship. (3) Campanian-Maestrichtian foraminifers define three major faunal provinces: Tethyan, Transitional, and Austral. The bathymetric distribution of benthonic foraminifers indicate that the foraminiferal lysocline and the carbonate compensation surface in the South Atlantic and Indian Ocean ranged between 3000 and 4000 meters. The geographic distribution of the provincial and abyssal foraminiferal assemblages resulted largely from oceanic circulation patterns. The striking similarity of Austral faunas and subsidence history from the eastern Falkland Plateau and the Magallanes Basin of South America suggest a predrift position for the Leg 36 sites adjacent to Patagonia and the Antarctic Peninsula. This position aligns the eastern Falkland Plateau faunas with Austral foraminifers from South America and New Zealand in the Pacific Ocean and away from Tethyan and Transitional faunas in the South AtlanticIndian Ocean.
\end{abstract}

\section{INTRODUCTION}

Leg 36 of the Deep Sea Drilling Project resulted in the drilling of 10 holes at six sites on the Falkland Plateau and the Falkland Outer Basin in the southernmost Atlantic Ocean Basin. Cretaceous foraminifers were recovered from three holes at two sites, 327 and 330 , on the eastern Falkland Plateau (Figure 1) and form the basis of this report. These faunas for the most part are well preserved and are of particular interest since (1) they represent the southernmost Cretaceous foraminifers yet recovered by the Deep Sea Drilling Project in the South Atlantic Ocean and thus are valuable for biostratigraphic and paleoecologic reconstructions, and (2) their original environment of deposition was oceanic and away from a dominant con- tinental influence and yet generally not deep enough to have been affected strongly by carbonate dissolution. The cores dealt with here from Sites 327 and 330 form a succession from early Albian to late Maestrichtian with a major hiatus present between the Cenomanian and Santonian. Paleoenvironmental and biogeographic patterns are interpreted within a time-stratigraphic framework based on planktonic and selected benthonic foraminifers.

\section{FORAMINIFERAL ASSEMBLAGES}

\section{Hole 327A}

This hole is located on the elevated eastern part of the Falkland Plateau (lat $50^{\circ} 52.28^{\prime} \mathrm{S}$, long $46^{\circ} 47.02^{\prime} \mathrm{W}$ ) at a water depth of 2410 meters (see Figures 1 and 2). 


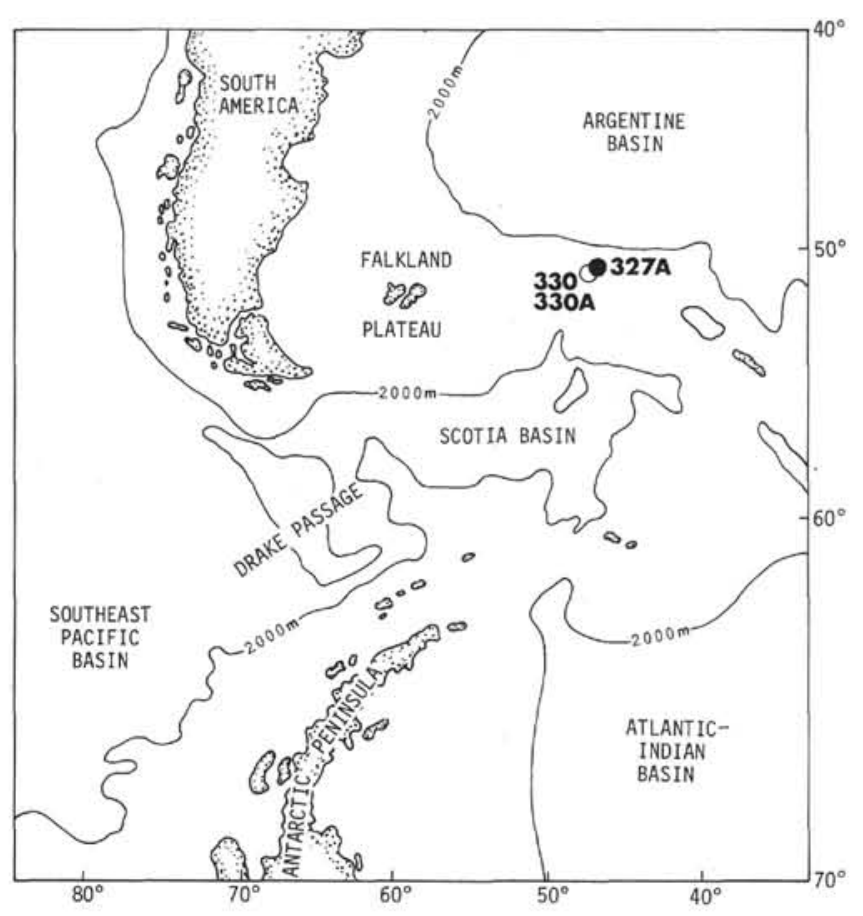

Figure 1. Location of DSDP Leg 36 Holes 327A, 330, and 330 A.

The first hole was abandoned after recovery of a surface core and a second hole (327A) was cored continuously to 118 meters and discontinuously to 470 meters before being abandoned. Twenty-seven cores were recovered with an average recovery rate of $50 \%$. Cretaceous foraminifers were found in Cores 10 to 21 .

\section{Albian-Cenomanian}

\section{Core 21}

Foraminifers from Core 21, Sections 1 to 4 (308.0$317.5 \mathrm{~m}$ ) are moderately well preserved and consist of numerous small planktonic species belonging to the genera Hedbergella and Globigerinelloides accompanied by a relatively diverse benthonic assemblage consisting of large agglutinated and calcareous species. Hedbergella planispira is the most common species followed by $H$. delrioensis and $H$. infracretacea (see Plates 1-13 for illustrations of planktonic foraminifers and selected benthonic species). Core 21 contains the restricted occurrence of Globigerinelloides gyroidinaeformis and the minute species Hedbergella sigali. The presence of these two species and the benthonic species Dorothia trochus, Gavelinella indica, G. intermedia, Gyroidinoides primitiva, Osangularia utaturensis, Spirobolivina australis, and Tribrachia australiana indicates an early to middle Albian age for Core 21. This age assignment agrees favorably with that determined from calcareous nannofossils (i.e., Parhabdolithus angustus Zone).

In addition to the above foraminifers, Core 21 faunas contain numerous nodosariids, fistulose polymorphinids, several encrusting species, rare praebuliminids, and worn miliolids including specimens of the genus Nodophthalmidium. Ostracodes are present as are occasional radiolarians and numerous Inoceramus prisms and shell fragments of the bivalve Aucellina.

\section{Cores 16-20}

Cores 16-20 (184.5-315.5 m) represent a continuation of the dominantly hedbergellid assemblages. Planktonic foraminifers are poorly to moderately well preserved with Hedbergella planispira and $H$. delrioensis being the most frequently occurring species followed by $H$. portsdownensis, $H$. amabilis, and $H$. infracretacea. Rare specimens of Globigerinelloides bentonensis and $G$. caseyi are also present. Benthonic assemblages again consist of large agglutinated and calcareous species that include Conorboides minutissima, Patellinella australis, Planularia bradyana, Pleurostomella obtusa, P. reussi, Dentalinopsis quadrata, Tritaxia gabonica, Uvigerinammina jankoi, and Vaginulina recta. These assemblages indicate a middle Albian age which is consistent with that determined from calcareous nannofossils (i.e., still within the Prediscosphaera cretacea Zone).

Additional faunal elements in these cores include numerous large nodosariids, fistulose polymorphinids, encrusting agglutinated and calcareous foraminifers, large agglutinated species including occasional specimens of Glomospira, large multibranched specimens of Ramulina, occasional ostracodes, radiolarians, echinoid fragments, Inoceramus prisms, and numerous fragments of Aucellina.

Planktonic foraminifers from Core 15 (175.0-184.5 $\mathrm{m})$ are dominated by Hedbergella planispira and $\mathrm{H}$. delrioensis and include $H$. infracretacea, $H$. portsdownensis, and the first appearance of Praeglobotruncana delrioensis. This assemblage plus the continuation of the underlying benthonic fauna indicate a late Albian age for this interval.

Foraminiferal preservation is similar to that in lower cores with a moderate increase in test dissolution. Likewise, the total fauna is little changed with the exception of an increase in praebuliminids, a reduction of Aucellina fragments, and a marked increase in Inoceramus prisms.

\section{Cenomanian}

Core 14 (part)

Cenomanian foraminifers were recovered from Core 14, Section 6, and Sample 327A-14, CC. This poorly preserved and moderately etched assemblage includes Praeglobotruncana delrioensis, Hedbergella planispira, $H$. delrioensis, and rare specimens and fragments of Schackoina cenomana and Rotalipora reicheli. Benthonic species likewise are poorly preserved and show an increase in gavelinellids and gyroidinoidids and agglutinated genera such as Glomospira and Glomospirella in addition to a sharp reduction in nodosariids. Inoceramus prisms flood the samples, but other bivalve fragments are rare.

In summary, the Albian to Cenomanian interval of predominantly nannofossil chalk is characterized by a consistent but low diversity planktonic fauna dominated by species of Hedbergella. Praeglobotruncana is next in abundance, and specimens of Globigerinelloides, Schackoina, and Rotalipora are rare. The 


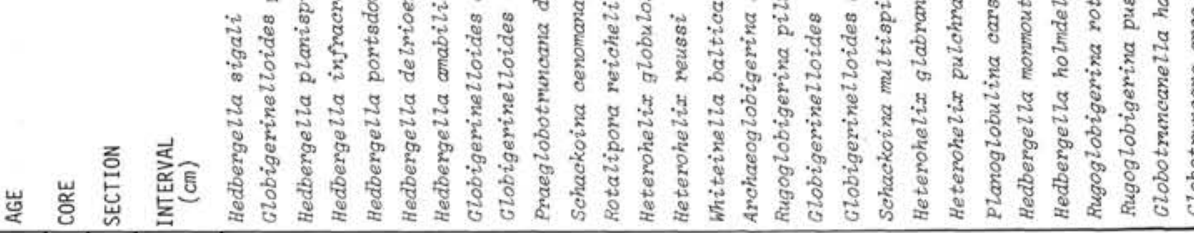

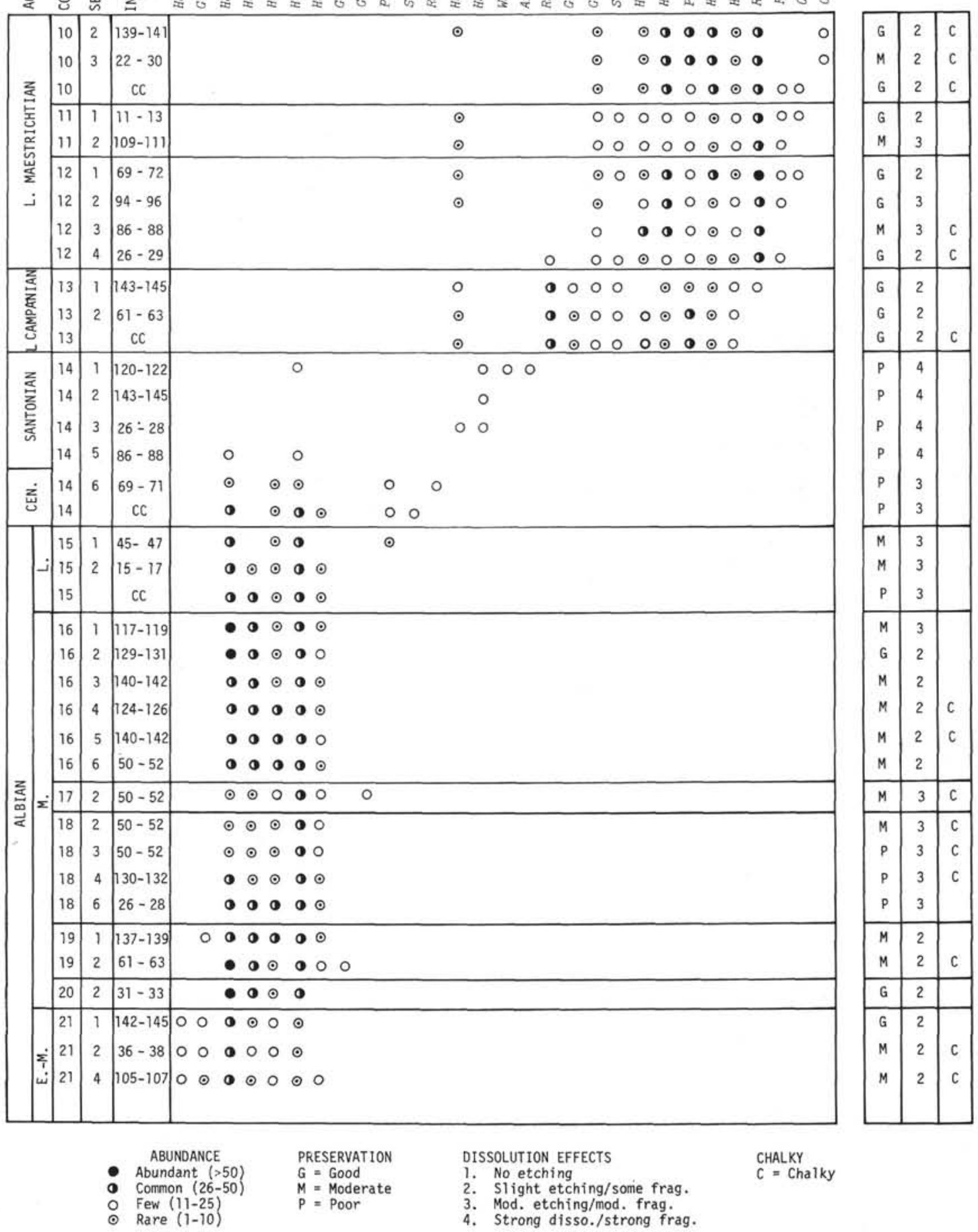

Figure 2. Distribution of Cretaceous planktonic foraminifers at Site 327. 
assemblage is distinguished by the lack of Albian-Cenomanian indicator species of Ticinella, Planomalina, or species of Rotalipora other than the rare specimens of $R$. reicheli.

\section{Santonian}

\section{Core 14 (part)}

Santonian foraminifers were identified in Core 14, Sections 1 to $5(146.5-151.0 \mathrm{~m})$. Foraminifers from this interval of zeolitic clay interbedded with micrite ooze are rare and poorly preserved and show the strong effects of dissolution. The planktonic assemblage is characterized by Heterohelix reussi, rare hedbergellids, and the restricted occurrence of Archaeoglobigerina bosquensis and Whiteinella baltica. This limited assemblage is accompanied by a dominantly agglutinated benthonic fauna associated with rare, resistant calcareous benthonics. The presence of the above globigerine-shaped planktonic species plus the benthonic species Aragonia materna kugleri and the first appearance of Gyroidinoides quadratus are indicative of a Santonian age.

Associated organisms in this interval include rare ostracodes and fish teeth, strongly corroded Inoceramus prisms, and abundant small calcareous objects that most closely resemble marine algae (see Plate 14). These hollow objects average $70 \mu \mathrm{m}$ in diameter and have nine sides, each penetrated by a single central perforation. Many show a sequence of secondary calcification that tends to infill the perforations and produce a globular shape. The calcareous objects were encountered only in the Santonian interval and represent a consistent component in these samples.

The strong dissolution and resultant low diversity foraminiferal fauna clearly distinguish this interval from adjacent units in Hole 327A.

\section{Campanian-Maestrichtian}

\section{Core 13}

Core $13(137.0-146.5 \mathrm{~m})$ sediments consist of a slightly mottled nannofossil ooze. Foraminiferal diversity, abundance, and preservation increase significantly over the underlying units. The abundant late Campanian planktonic assemblage is dominated by Rugoglobigerina pilula and heterohelicids that include Planoglobulina carseyae and Heterohelix glabrans. Species of Hedbergella and Globigerinelloides including a new species $G$. impensus (Plate 6, Figures 1-3) are also present, in addition to Schackoina multispinata.

Benthonic foraminifers also increase in diversity and abundance. The assemblage is characterized by gavelinellids, gyroidinoidids, large nodosariids that include fistulose polymorphinids, Neoflabellina praereticulata, Gyroidinoides quadratus, Globorotalites spineus, Reussella szajnochae, Bolivinoides laevigatus, Nuttallinella florealis, Gaudryina laevigata, and species of Pullenia and Pleurostomella. Rare worn miliolids and occasional ostracodes were also found in this interval.
Cores 10-12

Foraminifers recovered from Cores 10 to 12 (89.5$118.0 \mathrm{~m})$ are moderately diverse, abundant, and well preserved. The planktonic assemblage from this interval of foraminiferal-nannofossil ooze contains the last occurrence of Rugoglobigerina pilula followed by the common occurrence of $R$. rotundata, Heterohelix pulchra, H. globulosa, Hedbergella monmouthensis, and Planoglobulina carseyae. Of particular interest is the restricted occurrence of Globotruncana arca and Globotruncanella havanensis within this interval accompanied by Rugoglobigerina pustulata. This assemblage is placed in the late Maestrichtian. This age determination compares with a middle to late Maestrichtian age for Cores 10 and 11 based on calcareous nannofossils (i.e., Nephrolithus frequens Zone).

The benthonic assemblage is similar to that of the underlying unit with the addition of large Gaudryina pyramidata, Ammodiscus cretaceus, Pullenia cretacea, P. jarvisi, Gavelinella nacatochensis, Gyroidinoides nitidus, Stilostomella impensia, Ellipsoidella kugleri, Bolivina incrassata, Neoflabellina reticulata, and an increase in praebuliminids and species of Allomorphina and Quadrimorphina.

The significant increase in species abundance and diversity characterize the Campanian-Maestrichtian section. Rugoglobigerinids and heterohelicids dominate the planktonic assemblages and double-keeled globotruncanids are represented by rare specimens of a single species. This absence of important stratigraphic indicator species consisting primarily of double- and single-keeled globotruncanids represents a striking feature of this interval. Benthonic species also are more diverse; nevertheless they continue to represent a minor constituent of the total foraminiferal population typical of a pelagic environment.

\section{Site 330}

This site is located on the eastern end of the Falkland Plateau directly southwest of Site 327 (lat $50^{\circ} 55.19^{\prime} \mathrm{S}$, long $46^{\circ} 53.00^{\prime} \mathrm{W}$ ) at a water depth of 2636 meters (see Figures 1 and 3). Two holes were drilled with the primary objective of extending the Cretaceous stratigraphy below that recovered at Site 327. Hole 330 recovered 17 cores whereas only 5 were recovered from Hole $330 \mathrm{~A}$ before the latter was abandoned. Percentage core recovery from both holes was $53 \%$ and $8 \%$, respectively. Cretaceous foraminifers examined were from Cores 1 to 3 of Hole 330 and Cores 4, 5, and the bit sample of Hole 330A.

\section{Albian, Hole 330}

Foraminiferal assemblages in zeolite-rich nannofossil clay of Cores 1 and 2 are low diversity, predominantly well-preserved hedbergellid faunas dominated by Hedbergella planispira and $H$. delrioensis accompanied by $H$. amabilis, $H$. portsdownensis, and $H$. infracretacea. The presence of Hedbergella sigali in Sample 1, CC and Core 2 would indicate an early to middle Albian age whereas the absence of this species in Core 1, Section 1 , suggests a middle Albian age for this interval. No 


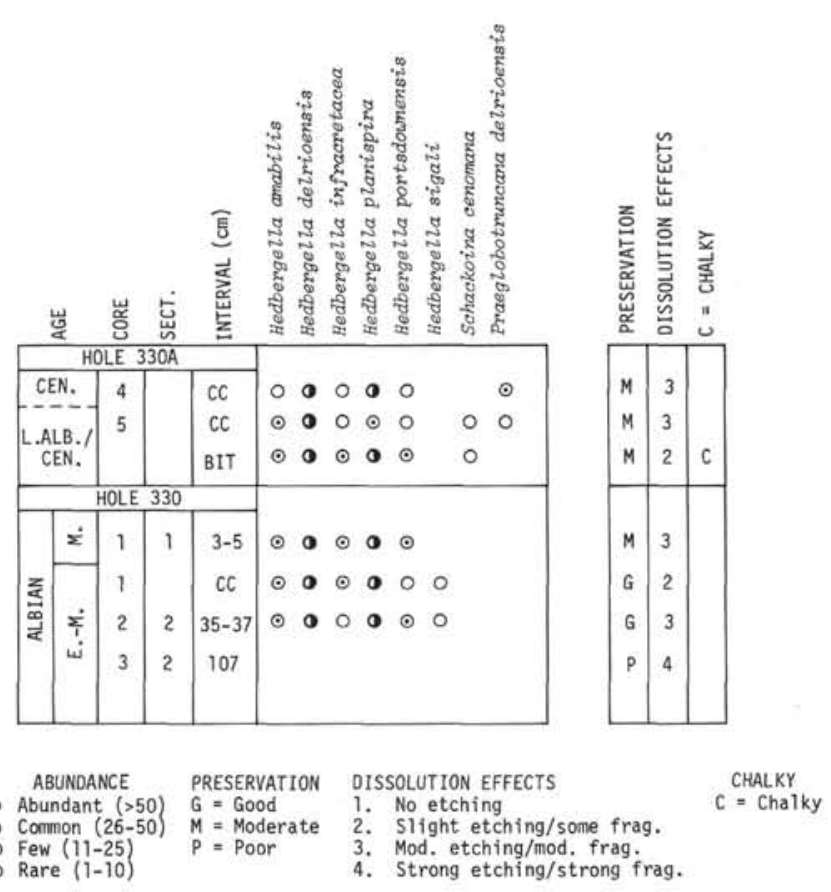

Figure 3. Distribution of Cretaceous planktonic foraminifers at Site 330.

foraminifers were recovered from Sample 3-2, $107 \mathrm{~cm}$; however, rare radiolarians are present.

Benthonic foraminifers from Cores 1 and 2 include Conorboides minutissima, Dorothia trochus, Osangularia utaturensis, Planularia bradyana, Tritaxia gabonica, and Uvigerinammina jankoi.

Additional faunal elements consist of ostracodes, echinoid fragments, radiolarians, Inoceramus prisms, and abundant shell fragments of the bivalve Aucellina.

\section{Albian-Cenomanian, Hole 330A}

As at Hole 330 , foraminiferal assemblages are dominated by a low diversity hedbergellid fauna. Hedbergella planispira and $H$. delrioensis are again the most common species. In contrast, however, the presence of Schackoina cenomana in the bit sample and Sample 5, $\mathrm{CC}$ plus the rare occurrence of Praeglobotruncana delrioensis suggest a late Albian to earliest Cenomanian age for these samples. Increased abundance of Praeglobotruncana delrioensis in Sample 4, CC indicate a Cenomanian age by this level.

Benthonic species are similar to those of Hole 330 with the addition of Spirobolivina australis and Vaginulina recta.

Associated with the foraminifers are ostracodes, echinoid fragments, radiolarians, Inoceramus prisms, and increasingly rare fragments of Aucellina.

\section{CORRELATION OF HOLE 327A WITH HOLES 330/330A}

Correlation of the Cretaceous cores from Leg 36 examined in the present study is summarized in Figure 4. Core 2 samples of Hole 330 are correlated with those of Core 21 of Hole 327A on the restricted occurrence of Hedbergella sigali and the accompanying Albian

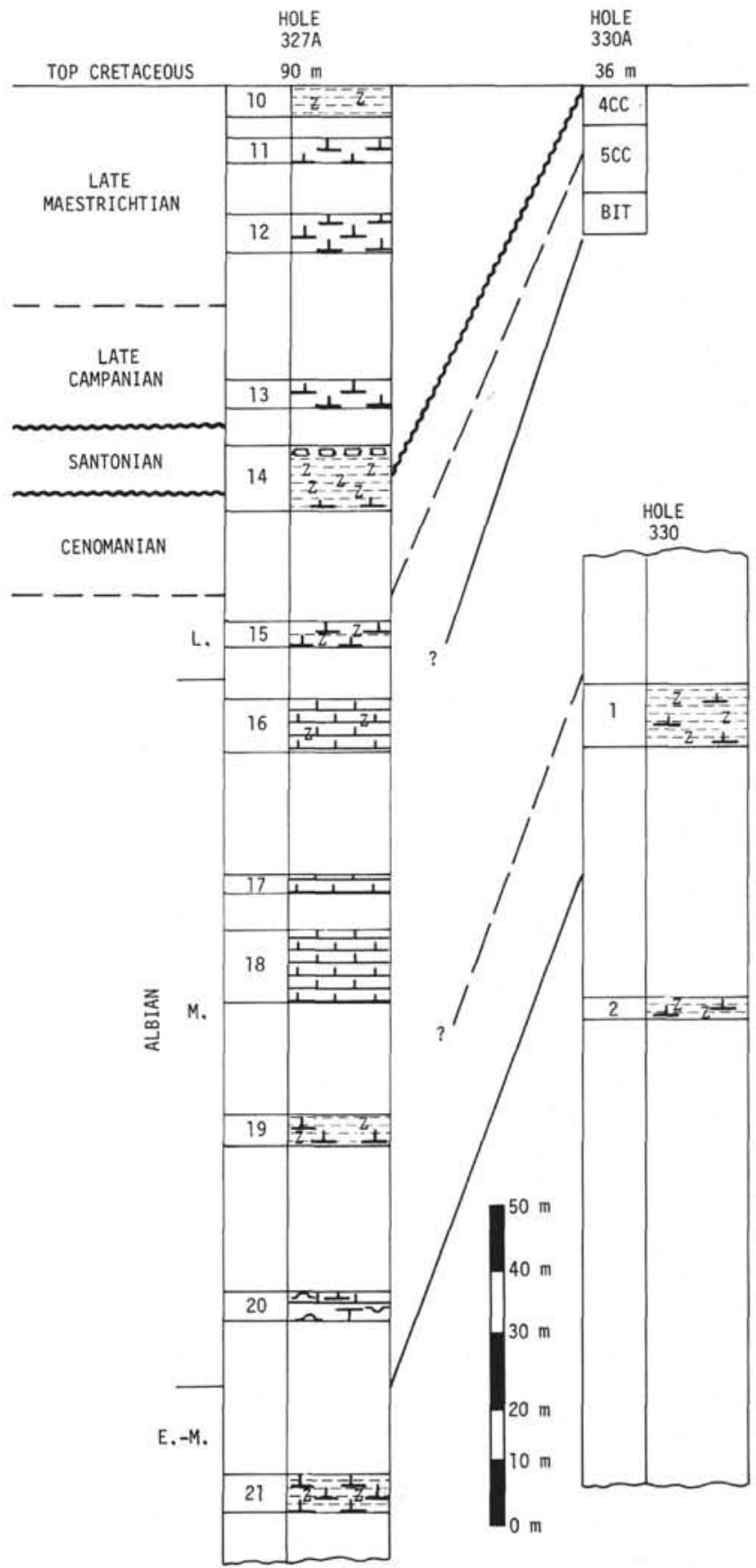

Figure 4. Stratigraphic correlation of selected Cretaceous cores from Holes $327 \mathrm{~A}, 330$, and $330 \mathrm{~A}$.

benthonic assemblage (see Figures 2 and 3). The foraminifers and zeolitic-rich sediments of Core 1 samples at Hole 330 appear to correspond to equivalent faunas and lithologies in Core 19 of Hole 327A.

At Hole 330A, the occurrence of Praeglobotruncana delrioensis and Schackoina cenomana plus the associated benthonic faunas indicate a correlation of Samples $330 \mathrm{~A}-5, \mathrm{CC}$ and $330 \mathrm{~A}-4, \mathrm{CC}$ with samples from $327 \mathrm{~A}-15$ and the Cenomanian portion of $327 \mathrm{~A}-14$, respectively. The samples from Hole $330 \mathrm{~A}$ thus lie beneath the prominent Cenomanian-Santonian unconformity found at Hole 327A. 


\section{PALEOECOLOGY}

Paleoecologic interpretation for Sites 327 and 330 is based upon the taxonomic composition of the foraminiferal assemblages and the relative abundance of the associated organisms (Figures 5-9). These faunal distribution patterns reflect a combination of changing environmental conditions and varying degrees of preservation. Carbonate dissolution, both primary and secondary, strongly affects the recovery and fragmentation of foraminiferal assemblages. As has been demonstrated for modern planktonic foraminifers (Berger, 1970) and for fossil planktonic and benthonic species (Sliter, 1975), the selective removal and consequent enrichment of resistant species by carbonate dissolution can greatly affect the resultant paleoecologic interpretation.

The following examination will begin with the oldest units at each site and proceed to the youngest. Percent determinations are based on counts of 300 specimens from a size fraction greater than $140 \mu \mathrm{m}$. These counts were maintained throughout the study except where specimens were severely reduced in number such as the Santonian unit of Hole 327A. The size split at $149 \mu \mathrm{m}$ effectively removed the majority of benthonic specimens from the floods of smaller planktonics.

\section{Site 327}

Faunal components from the Albian interval of Hole 327A (Cores 21 to 15), in particular the foraminiferal assemblages, strongly resemble those from modern low-latitude shelf-edge environments or from outer neritic to upper bathyal water depths $(100-400 \mathrm{~m})$. Further, several of these components indicate a trend of gradually increasing water depth that becomes accentuated in Core 15.

Benthonic foraminiferal assemblages from the Albian interval are characterized by genera such as $\mathrm{Am}$ modiscus, Conorboides, Dorothia, Gavelinella, Gyroidinoides, Nodophthalmidium, Osangularia, Patellinella, Patellinoides, Pleurostomella, Spirobolivina, Tritaxia, Uvigerinammina, numerous large nodosariids that include Dentalina, Frondicularia, Lenticulina, Marginulina, Nodosaria, Planularia, and Tribrachia, polymorphinids, encrusting calcareous and agglutinated species, large branching specimens of Ramulina, and rare miliolids and praebuliminids. Considered as a whole, these foraminifers are indicative of outer neritic-upper bathyal Cretaceous environments (Sliter and Baker, 1972).

The slight reduction in benthonic specimens from Core 21 to Core 15 (Figure 5) indicates a gradual deepening of the paleoenvironment. A portion of the high benthonic percentages in Core 21 , however, are related to preservation as evidenced by the increased abundance of resistant agglutinated species and the typically thicker-walled members of the Cassidulinacea (Figure 6), and the increased fragmentation of benthonics (Figure 7). Nevertheless, the overall trend toward fewer, more fragmented benthonics plus the change in the foraminiferal assemblage of Core 15 such as the increased size of specimens of Gavelinella, Gyroidinoides, and agglutinated genera, an increase in the abundance of specimens of Conorboides, Praebulimina, and Uvigerinammina and a reduction in the abundance of large nodosariids serve to define a shift in the benthonic environment toward deeper water depths.

Planktonic species show a prominent increase in percentage from Core 19 to Core 15 (Figure 5) that also reflects the change toward a deeper paleoenvironment. The abundance of planktonic foraminifers in the Albian section reaches its peak in Core 15. The apparent reduction in planktonic abundance toward the top of Core $15(327 \mathrm{~A}-15-1)$ is due to the increase of Inoceramus prisms which flood the samples. It must be remembered, however, that the planktonic percentages shown in Figure 5 are based on specimens greater than $149 \mu \mathrm{m}$ in size and thus they do not record the generally abundant small hedbergellids that occur in varying numbers in all samples. Nevertheless, the abundance of these small specimens roughly approximates the trend shown in Figure 5.

Associated organisms are dominated by bivalve fragments, predominately of the genus Aucellina, with lesser occurrences of radiolarians, Inoceramus prisms, echinoid fragments, and ostracodes (see Figure 5).

Radiolarian occurrences in Cores 21,19 , and 18 in large part represent selective preservation and a subsequent enrichment of noncalcareous material. This is illustrated by the corresponding decrease in bivalve fragments (Figure 5) and an increase in both agglutinated foraminifers (especially in Core 21) and the fragmentation of planktonic specimens (Figure 7).

Inoceramus prisms, which formed a low background percentage through most of the Albian interval, suddenly became the dominant faunal element in Core 15 (Figure 5). Several factors accompany this change such as a sharp decrease in bivalve fragments, an increase in both planktonic percentage and fragmentation, and a fluctuation in sample preservation. These patterns are most probably from a change in depositional environment that progressed from a predominantly shelfrelated habitat to a slope habitat of from bathyal to abyssal water depth. The abundance of Inoceramus prisms may represent the transportation and winnowing of these prisms of uniform shape and size in distal fan deposits or by newly formed deep-water currents.

Faunal components of the Cenomanian samples of Core 14 record a continuation of the accelerated bathymetric deepening begun in Core 15 . The samples are dominated by representatives of Gavelinella, Gyroidinoides, and agglutinated genera. Further changes in the assemblages include the appearance of species of Glomospira and Glomospirella and a sharp reduction or disappearance of large nodosariids, fistulose polymorphinids, and encrusting species. Also consistently present are species of Pleurostomella.

Partially dissolved Inoceramus prisms represent the dominant accessory component whereas bivalve fragments and radiolarians are rare (Figure 5).

Preservation of the Cenomanian foraminiferal assemblage is poor and the specimens are moderately etched which, along with the corroded Inoceramus prisms, indicates that water depths were near or below 


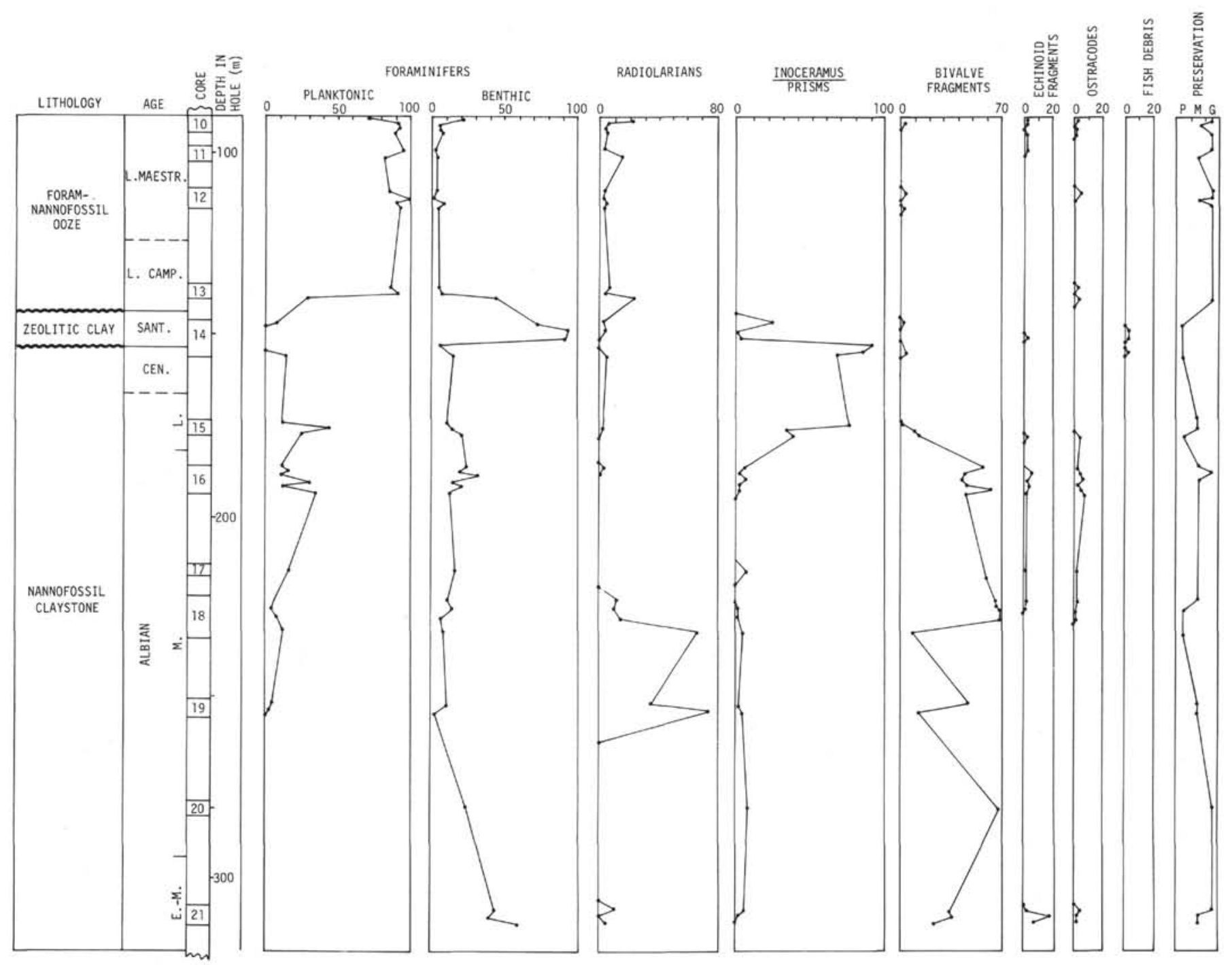

Figure 5. Comparison of the abundance of foraminifers and associated organisms (cumulative percent) and foraminiferal preservation from Hole $327 \mathrm{~A}$.

the Cretaceous foraminiferal lysocline. This conclusion is supported by the increased percentage of planktonic fragments (Figure 7). Dissolution, however, was not severe as evidenced by the minor changes in the abundance of agglutinated foraminifers, the resistant calcareous members of the Cassidulinacea, and radiolarians.

Foraminifers from the Santonian mottled zeolitic clay (Core 14, Sections 1 to 5) are strongly corroded and consist primarily of rare agglutinated and resistant calcareous species (see Figure 7). Present are agglutinated genera such as Bathysiphon, Dorothia, Gaudryina, Glomospira, Glomospirella, Haplophragmium, Hyperammina, Kalamopsis, Lituotuba, Spiroplectammina, Tritaxia, large Ammodiscus, globose Haplophragmoides, and very rare, generally fragmented specimens of calcareous genera such as Allomorphina, Aragonia, Gavelinella, Gyroidinoides, Osangularia, Pleurostomella, and Pullenia. This foraminiferal association is equivalent to modern low-latitude assemblages from abyssal environments (2500 to 4000 $\mathrm{m})$. Further, benthonic environments were within the foraminiferal lysocline and close to or below the carbonate compensation surface based on the poor preservation of the foraminiferal assemblage.

Inoceramus prisms reach their peak abundance in the lower samples of this unit and are then followed by a sharp reduction (Figure 5). In the upper samples the prisms are strongly corroded and form a minor component of the assemblages. Fish debris is also common in the samples of this dissolution facies.

Campanian samples of Core 13 record a return of lower bathyal foraminiferal assemblages (1500-2500 $\mathrm{m})$. Larger planktonic foraminifers represent the dominant faunal component (Figure 5). Of the planktonic specimens, $20 \%$ to $25 \%$ are fragmented, indicating a bathymetric position near or beneath the foraminiferal lysocline. Benthonic foraminifers are diverse and abundant and include species of Allomorphina, Ellipsoidella, Gavelinella, Globorotalites, Gyroidinoides, Nuttallinella, Osangularia, Pleurostomella, Pullenia, Quadrimorphina, Reussella, and Stilostomella. Admixtures of shelf species are represented by worn miliolids and nodosariids, bored polymorphinids (see Sliter, 1971), 


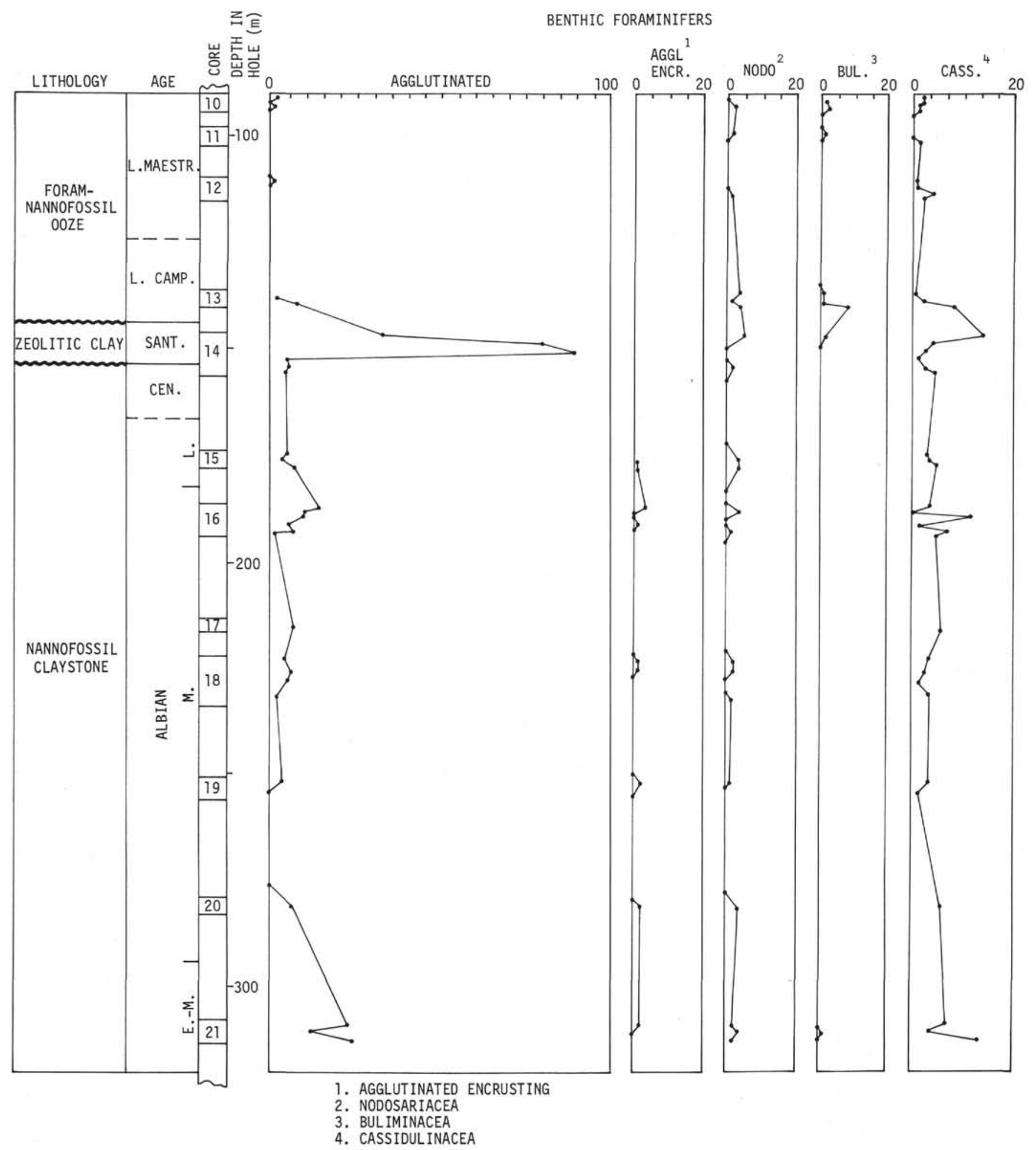

Figure 6. Comparison of the abundance of selected benthonic foraminiferal groups and superfamilies from Hole 327A. (Cumulative percent on benthonic foraminifers in the total assemblage.)

rare specimens of Carpenteria, and occasional shell fragments that contain algal borings. Praebuliminids become a persistent element of the foraminiferal assemblages for the first time and associated organisms consist of radiolarians and occasional ostracodes.
The presence of Santonian abyssal assemblages followed by bathyal faunas in the Campanian could be explained by subsidence of the Falkland region followed by uplift. A second and perhaps more likely explanation, however, involves an alteration of the 


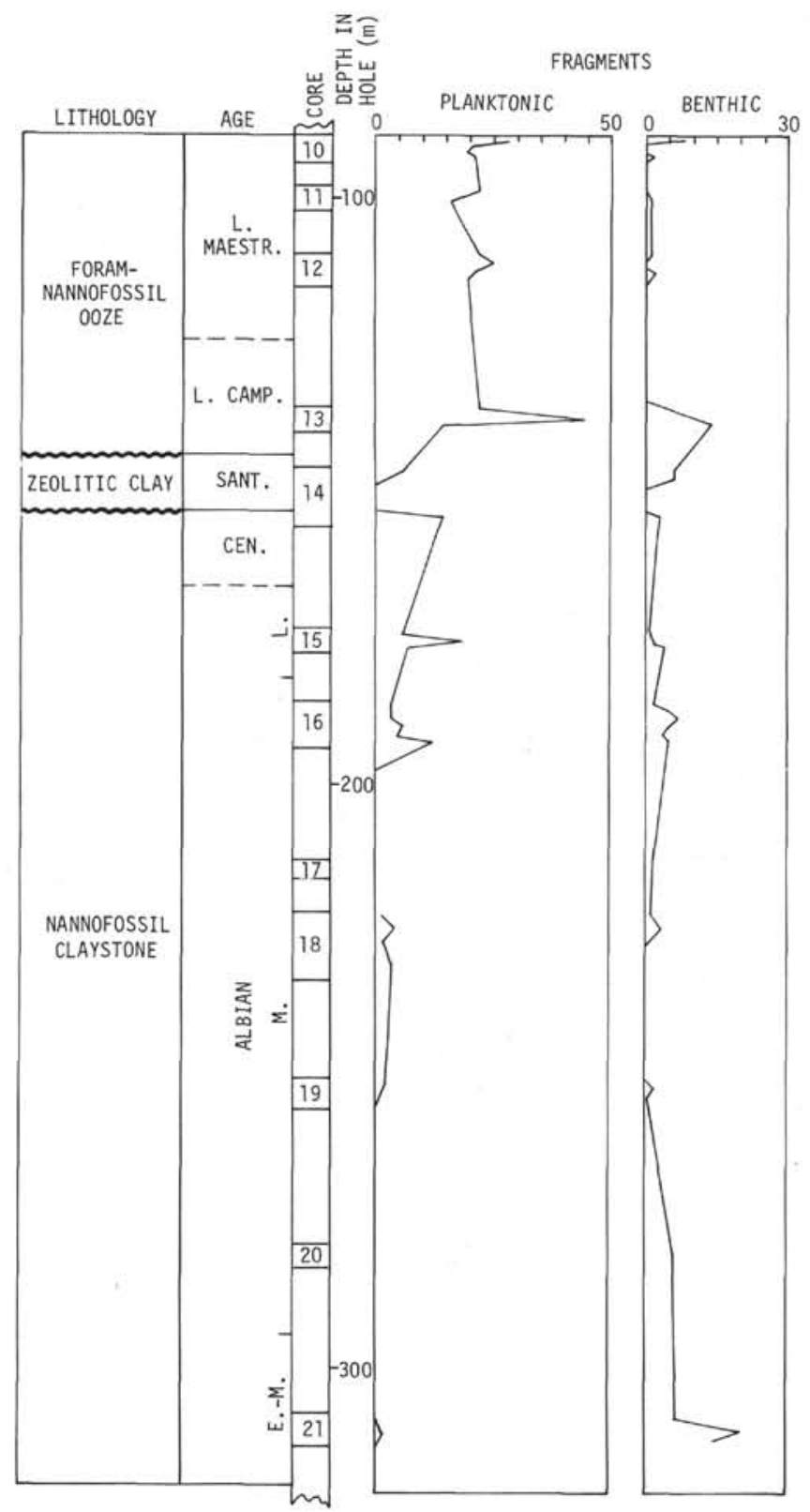

Figure 7. Comparison of the abundance of fragmented specimens from Hole $327 \mathrm{~A}$ (percent of fragments in total assemblage).

hydrographic conditions such as changes in both the temperature and source of the bottom water (see below) that combined to raise the foraminiferal lysocline into shallower water depths. Correspondingly, the original bathyal assemblage in the Santonian section was modified or displaced by the upward migration of the abyssal fauna. The Campanian assemblages record an amelioration of the bathyal environment and a return to less deleterious bottom conditions.

Maestrichtian assemblages in Cores 10 to 12 are composed of species equivalent to modern low-latitude lower bathyal faunas. This depth approximation encompasses the present water-depth range of Site 327A, i.e., from 2400 to 2500 meters. Benthonic assemblages represent a continuation of those in Core 13. Faunas show an increase in both benthonic abundance and the size of the largest specimens. Little difference is noted in species content with the exception of a slight increase in specimens of Bolivina, Ellipsoidella, and Quadrimorphina and somewhat fewer specimens of Reussella and larger nodosariids. Admixtures of shelf faunas are indicated by the presence of rare encrusting agglutinated foraminifers, occasional fistulose polymorphinids, abraded miliolids and rare fragments of Neoflabellina.

Planktonic foraminifers continue to dominate the samples and associated organisms include radiolarians, rare bivalve fragments, some echinoid fragments, and occasional ostracodes.

\section{Hole 330}

Albian foraminifers from Cores 1 and 2 indicate shelf-break environments of from outer neritic to upper bathyal water depths $(100-400 \mathrm{~m})$. The benthonic assemblages are dominated by large nodosariids, agglutinated genera such as Ammodiscus, Dorothia, Gaudryina, and Tritaxia and species of Gavelinella and Gyroidinoides. Also present are species of Pleurostomella, Patellinoides, rare specimens of Uvigerinammina and Praebulimina, branching specimens of Ramulina, and encrusting genera.

Planktonic species increase in abundance from Section 330-2-2 to Section 330-1-1 (Figure 8). This trend is opposite that of members of the Cassidulinacea that show a decrease in abundance in later samples (Figure 9). Fragments of the bivalve Aucellina are the dominant accessory organism an all samples and they become increasingly abundant in the later samples. Inoceramus prisms show a similar trend whereas radiolarians are more abundant in the earlier samples (Figure 8). These trends reflect, in part, changes in preservation that contributed to the enrichment of noncalcareous or resistant calcareous benthonics in the early samples. The correlations of Hole 330 with Hole 327A (Figure 4) are supported by the percentages of associated organisms that show similar trends in bivalve fragments, radiolarians, and Inoceramus prisms (see Figures 5 and 8).

\section{Hole 330A}

Foraminiferal assemblages from Hole 330A show a strong general resemblance to those from Hole 330. Somewhat deeper water depths are indicated, however, by both the foraminiferal fauna and the associated organisms. Benthonic assemblages are dominated by specimens of Gavelinella, Gyroidinoides, and agglutinated genera. The abundance of nodosariids is reduced whereas specimens of Osangularia, Pleurostomella, Praebulimina, Pullenia, and Uvigerinammina increase. This assemblage indicates upper bathyal water depths of at least 400 meters (Sliter and Baker, 1972). Planktonic foraminifers and fragmented specimens both increase in these samples as do the percentages of radiolarians and Inoceramus prisms (see Figures 8 and 9). Bivalve fragments that were in abundance in Hole 

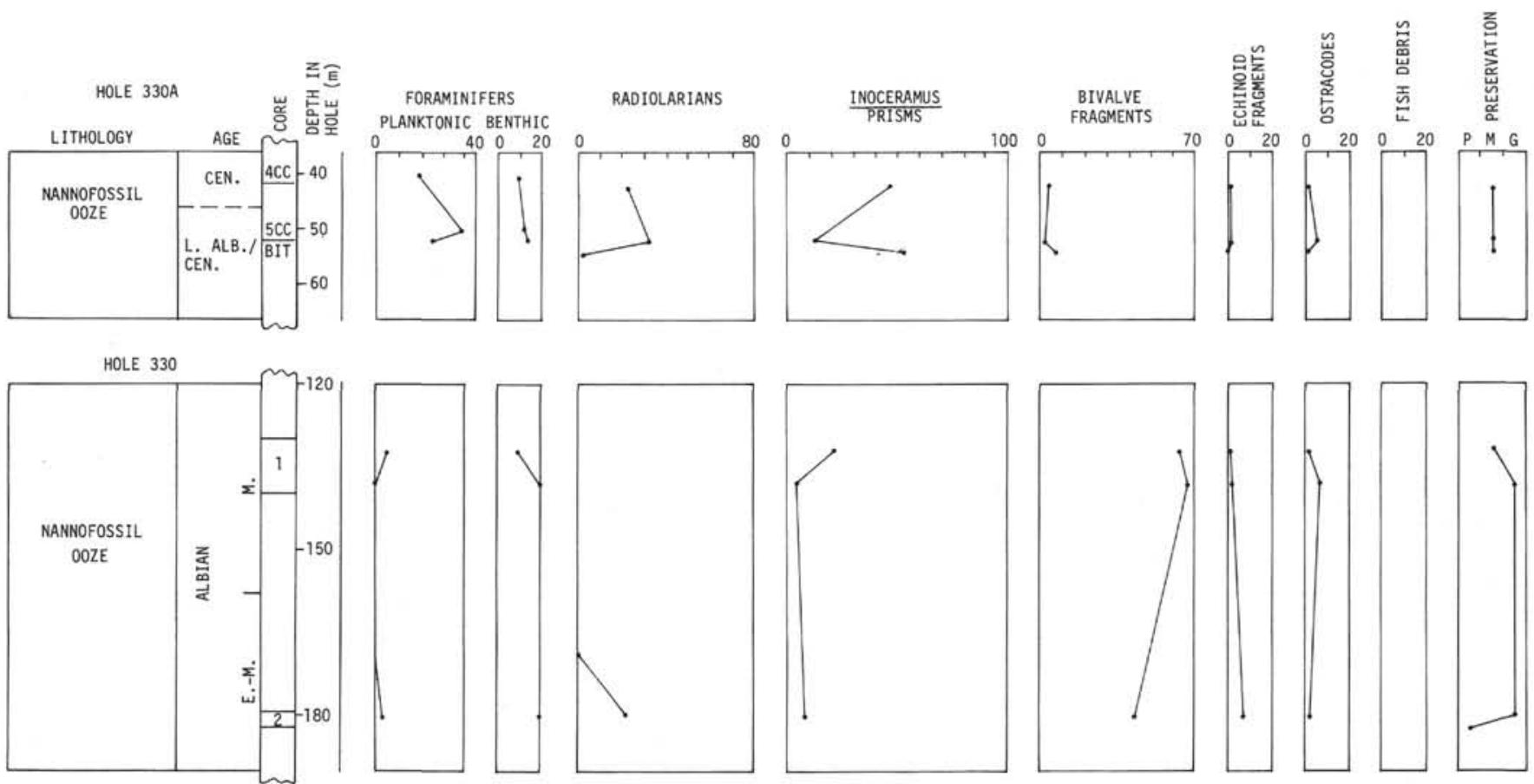

Figure 8. Comparison of the abundance of foraminifers and associated organisms (cumulative percent) and foraminiferal preservation from Holes 330 and $330 \mathrm{~A}$.

330 are now greatly reduced in number signifying the change in depositional environment. Again, the percentages of associated organisms corroborate this correlation shown in Figure 4 as shown by similar trends in planktonic foraminiferal abundance and fragmentation, Inoceramus prisms, and bivalve fragments (see Figures 7 and 9).

\section{COMPARISONS}

\section{Southern Hemisphere DSDP Sites}

Leg 36 planktonic foraminifers most closely resemble those described from Legs 26 and 27. Albian planktonic species illustrated and described by Krasheninnikov (1974) from Leg 27, Sites 259 and 260 offshore Western Australia are nearly identical to those from Leg 36 . These assemblages are distinguished by the absence of Albian-Cenomanian indicator species of Clavihedbergella, Planomalina, Ticinella, and early representatives of Rotalipora.

Leg 26 planktonic foraminifers reported by Herb (1974) from Sites 256, 257, and 258 in the eastern Indian Ocean again are similar to those from Leg 36. These assemblages range in age from Albian to Santonian and are characterized by species of Hedbergella, Globigerinelloides, Archaeoglobigerina, and Whiteinella as are those from Leg 36. These assemblages differ, however, in the presence of Ticinella in the Albian samples of Site 257 and species of Praeglobotruncana, Marginotruncana, and Globotruncana from the Turonian to Santonian samples of Site 258, species or genera that were not recovered from Leg 36 .

A strong similarity exists between the Albian benthonic foraminifers described by Scheibnerová
(1974) from Leg 27 Sites 259, 260, and 263 and those from Leg 36 . The assemblages from both legs are very similar in species diversity, morphologic characteristics, and stratigraphic distribution. Likewise, the agglutinated benthonic assemblages described by Krasheninnikov (1974) from deep-water brown zeolitic clays of Leg 27, Sites 260 and 261 resemble those recovered from Santonian samples of Leg 36, Hole 327A. Based on the age of redeposited planktonic foraminifers, the Leg 27 assemblages were judged to range in age between late Turonian-Coniacian and early Campanian. The Leg 27 faunas differ, however, in their increased diversity and better preservation.

Campanian-Maestrichtian planktonic faunas of $\mathrm{Leg}$ 36 remain unique in both the dominance of rugoglobigerines and the rarity or absence of other planktonic genera when compared to coeval assemblages from previous DSDP sites (for more detail see below).

\section{Continental Foraminiferal Assemblages}

Close correspondence exists between Leg 36 Cretaceous benthonic foraminifers and those described from Western Australia. Benthonic assemblages from both the Gingin Chalk (Santonian) and Toolonga Calcilutite (Santonian to early Campanian) described by Belford (1960) contain many of the species present at Hole 327A. Similar correspondence exists with other Australian benthonic assemblages notably those reported by Belford and Scheibnerová (1971), Crespin (1963), Edgell (1954), and Scheibnerová (1972). Conversely, Australian Cretaceous planktonic assemblages reported by Belford (1960), Belford and Scheibnerová (1971), and Edgell (1957) contain a greater diversity than those of Leg 36 . Nevertheless, the 


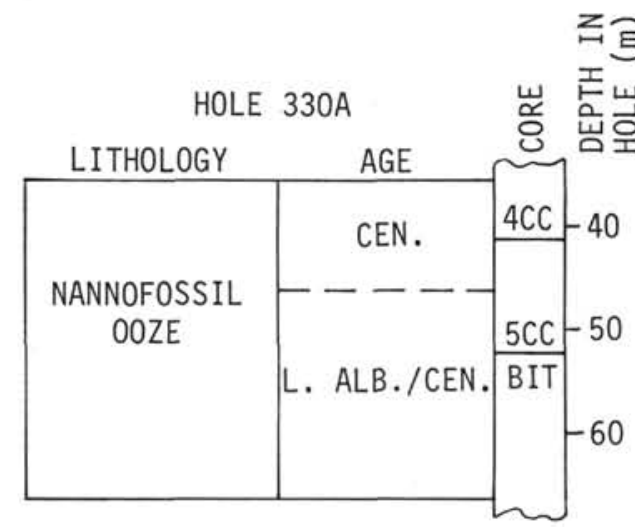

FRAGMENTS
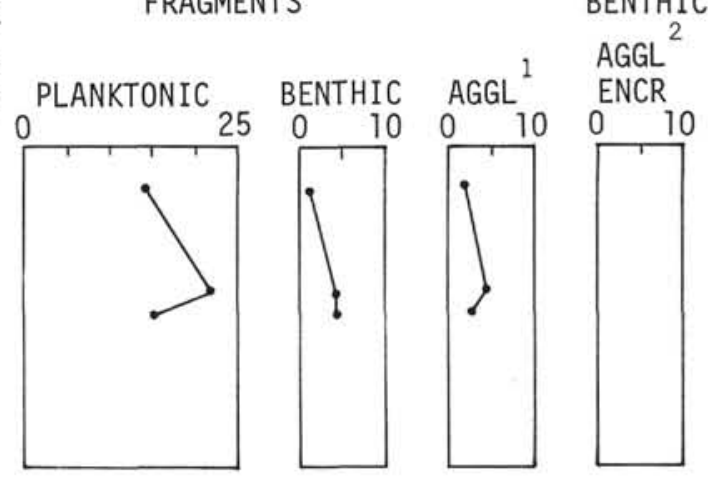

AGGL $^{2}$

FORAMINIFERS
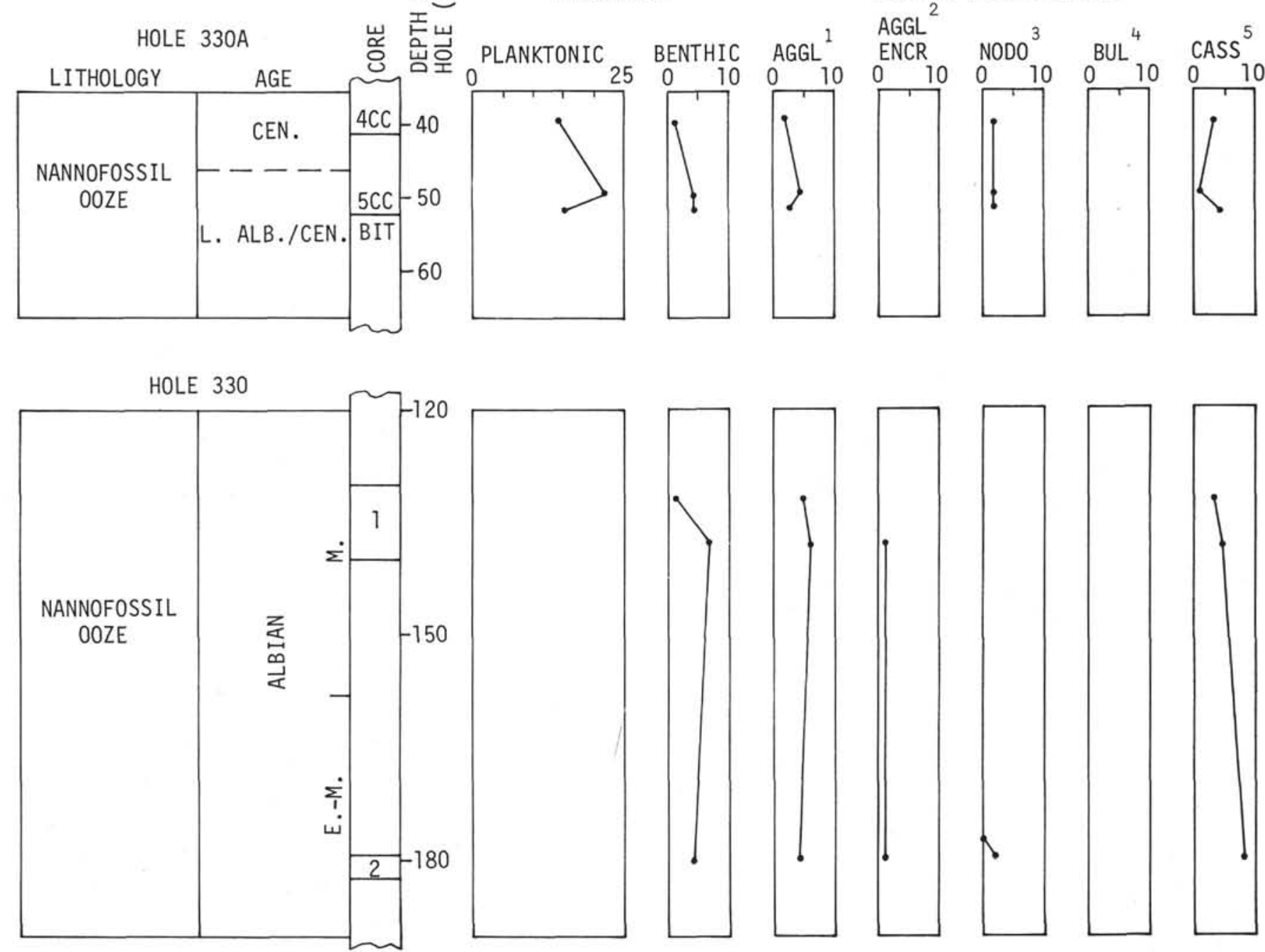

1. AGGLUT INATED

2. AGGLUTINATED ENCRUSTING

3. NODOSARIACEA

4. BUL IMINACEA

5. CASSIDUL INACEA

Figure 9. Comparison of abundance of fragmented specimens (percent fragments in total assemblage) and selected benthonic foraminiferal groups from Holes 330 and $330 \mathrm{~A}$ (cumulative percent of benthonic foraminifers in total assemblage).

Austral character of the assemblages can be seen in the predominance of species of Hedbergella, Heterohelix, Globigerinelloides, Rugoglobigerina, and Whiteinella.

Cretaceous foraminiferal assemblages from the Magallanes Basin of southernmost Chile and Argentina (Herm, 1966; Malumian, 1969; and Natland et al., 1974) show similarities to those of Leg 36. As with Australian faunas, a greater similarity exists with benthonic species whereas planktonic assemblages again show a greater diversity of globotruncanids.

In contrast, planktonic assemblages from South Africa described by Lambert (1971) from deposits of pre-Coniacian to Maestrichtian age show a diversity of species typical of warmer waters. Many similarities to Leg 36 faunas do exist, however, in both the diverse benthonic assemblages and with certain elements of the planktonic faunas.

\section{FORAMINIFERAL PROVINCES AND DISSOLUTION FACIES IN THE SOUTHERN HEMISPHERE}

The results of DSDP legs which recovered Cretaceous material in the southern hemisphere were investigated to determine the significance of the Cretaceous foraminiferal data from Leg 36 . These results derived from Initial Reports published or in press and published Geotimes articles are summarized in Figure 10. Paleontologic and lithologic data shown were taken directly from the above sources whereas the faunal province and bathymetric interpretations were made by the author primarily from the reported foraminiferal faunas. Provincial information was derived where possible from the species composition of the planktonic fauna. This information in the form of 


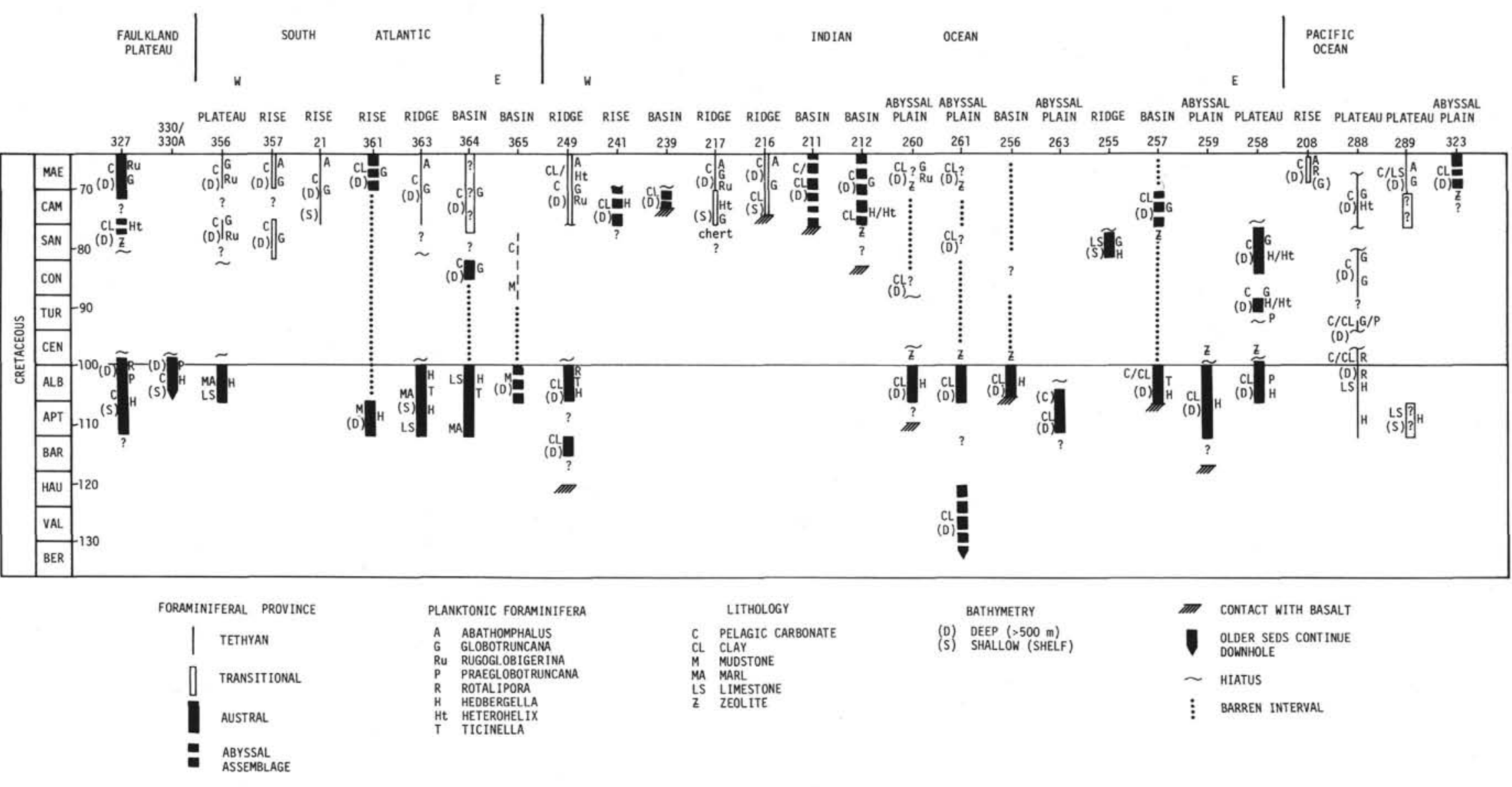

Figure 10. Cretaceous planktonic foraminiferal faunas; sediments, unconformities, and dissolution facies at southern hemisphere DSDP sites. Data from Burns, Andrews, et al., 1973; von der Borch, Sclater, et al., 1974;Simpson, Schlich, et al, 1974; Davies, Luyendyk, et al., 1974; Veevers, Hiertzler, et al., 1974; Hollister et al., 1974; Perch-Nielsen et al., 1975; Bolli et al., 1975; Andrews, Packham, et al., 1976. 
selected genera has been added to Figure 10. For those sites where planktonics are absent the provincial or assemblage determination was made from the species composition of the benthonic assemblage. In the latter case, no faunal information was added to Figure 10.

The following interpretation of the foraminiferal distribution patterns is based on a brief examination of several factors such as continental drift, climatic change, and oceanic circulation. It is obvious, however, that these and other factors interact in a complex fashion that affects oceanic productivity, carbonate dissolution, and evolutionary rates. Studies of these interrelated factors during the Cretaceous are as yet in a preliminary stage. However, several excellent summaries have been published (e.g., Berggren and Hollister, 1974; Gartner et al., 1974; Luyendyk and Davies, 1974; Scheibnerová, 1971, 1973).

From the examination of Figure 10, three main features are apparent: (1) Aptian to early Cenomanian foraminiferal faunas from southern hemisphere localities in the South Atlantic and Indian Ocean, regardless of the interpreted water depth, show a similar Austral provincial character. This is recognized by the dominant hedbergellid planktonic faunas with rare occurrences of Ticinella, Praeglobotruncana, or Rotalipora. In other words, Tethyan or Transitional faunas are rare or absent. (2) A prominent hiatus or barren interval ranging in age from the AlbianCenomanian to the Santonian-Campanian exists at many sites. (3) Foraminiferal faunas from Santonian to Maestrichtian intervals show an increased diversity of planktonic species and faunal provinces. In addition, the data show two localized trends: the general absence of Campanian-Maestrichtian sediments from the eastern Indian Ocean sites and the youthful age of basement of the Ninetyeast Ridge (Sites 216, 217) and the adjacent Wharton Basin (Sites 211, 212).

\section{Aptian-Albian Austral Foraminifers}

Aptian-Albian foraminiferal faunas from the lower southern hemisphere are Austral or extratropical in provincial character. This refers to assemblages that are low in species diversity and dominated by small hedbergellids. Typical Tethyan species are lacking or occur in low numbers. Several factors interact to explain this faunal character.

First, the majority of sites with Aptian-Albian foraminifers lie south of $40^{\circ} \mathrm{S}$ latitude on paleoreconstructions. It seems obvious that the restricted diversity at many of these sites reflect the lower water temperature of the Austral marine environment. Corroborating this interpretation is the similarity of faunal character at sites with differing paleobathymetry. These benthonic environments range from the deep-water sites of Legs 26 and 27 off Western Australia to the shelf environments of Leg 36 .

Second, Albian continental positions served to isolate the southern hemisphere sites and restrict oceanic exchange (Luyendyk, 1974). This is especially true of the South Atlantic sites that lacked or had minimal surface water exchange with low-latitude Tethyan assemblages during the Aptian-Albian. Further, sites off Western Australia were isolated from the Western Indian Ocean by the southern position of the Indian plate (Sclater et al., 1974). This combination of lower temperature, restriction of ocean basin size, and isolation from Tethyan exchange is believed to be primarily responsible for the Austral foraminiferal character. The distinctive Aptian-Albian Tethyan foraminifers from Site 288 contrast with those of the Austral province and correspond to the lower latitude, central southern Pacific position of this site and Site 289 on the Pacific plate during the mid-Cretaceous.

A third and complicating combination of factors that cannot be disregarded involves the selected removal of planktonic and benthonic species by sediment transport and dissolution. A local assemblage resembling an Austral fauna could be produced by this screening process especially in deep-water Aptian-Albian environments such as those off Western Australia and in the eastern South Atlantic. While obviously important, selective preservation is not regarded as a primary factor in determining the regional Austral character of the Aptian-Albian foraminifers. This interpretation is substantiated by the presence of additional Austral elements such as benthonic foraminifers, belemnites (Stevens, 1974), bivalves (Speden, 1974; Jones and Plafker, this volume), and calcareous nannofossils (Thierstein, 1974) associated with the planktonic foraminifers.

\section{Cenomanian-Santonian Hiatus}

A mid-Cretaceous hiatus is noted throughout the southern hemisphere DSDP sites (Figure 10). The duration commonly ranges from the late Albian-Cenomanian to the Santonian. The regional extent of this hiatus is obvious as it affects all of the southern oceans. In fact, it is intriguing to speculate that the mid-Cretaceous hiatuses and intervals barren of foraminifers recognized in the North Atlantic (Pimm and Hayes, 1972 ) and the North Pacific (Douglas et al., 1973b; Luterbacher et al., 1975) are also related to the same causative events.

The hiatus typically takes the form of a dissolution facies accompanied by zeolitic clays, absence of calcareous material, and lowered sedimentation rates. Dissolution presently is known to occur below the carbonate compensation surface (CCS) or that level where carbonate solution equals carbonate supply. The CCS can be moved shallower or deeper by alteration of the bathymetric regime through changes in oceanic circulation, sedimentation rate, climate, and oceanic productivity (Berger and Winterer, 1974). In the following paragraphs, several mid-Cretaceous events are briefly evaluated as to the role they may have played in the development of the dissolution facies. Interestingly, foraminiferal assemblages indicate a change in environmental conditions just prior to the onset of the hiatus at several DSDP sites such as that observed at Sites 327A, 249, and 258. At these locations changes in the planktonic and benthonic assemblages indicate an increase in water depth or a change in oceanic circulating patterns or both.

During the mid-Cretaceous, several tectonic events altered previous oceanic conditions. Opening of the Indian Ocean that had begun in the Valanginian with the northward rifting of Africa, Madagascar, and India continued in the Albian-Cenomanian. By mid- 
Cretaceous, Africa and Madagascar/India had separated thus opening the western Indian Ocean. The northern portion of the South Atlantic opened during this interval; however, Tethyan exchange was still limited if it existed at all. Opening of the Weddell and Scotia seas perhaps began at this time followed thereafter by the initial break between the Andes and Antarctandes (Dalziel et al., 1972; Luyendyk, 1974). There is some evidence to suggest that the incipient rift between Australia and Antarctica may have been initiated during the mid-Cretaceous corresponding to marine sedimentation in southern Australia. Oceanic circulation was strongly affected by the enlarging of the southern oceans, the access to Tethyan waters through the Indian Ocean, and the initiation or increased flow of Pacific water through the Antarctic Peninsula and perhaps through a trench lying to the east of Ellsworth Land. As a result of these tectonic events, oceanic circulation patterns were altered and bottom circulation was intensified. One result may have been the initial formation of a circum-Antarctic/Australia surface current.

Cycles of marine transgression and regression and paleotemperature show some correspondence with the deep-sea environmental changes (Figure 11). Following a general transgressive phase extending from the Barremian to the Albian a series of regressions and transgressions characterize the Cenomanian to Campanian interval. The first of these major cycles takes place within the Cenomanian. These eustatic changes in sea level are defined in the sedimentary records of marginal cratonic marine basins. For example, in the marginal basins of Western Australia the Coniacian and part of the Turonian are absent (Veevers and Johnston, 1974). In addition, the authors noted a direct correlation of Early Cretaceous lithologic sequences followed by a late Albian-Cenomanian unconformity between selected offshore wells and DSDP sites from Legs 26 and 27. The marginal basins of eastern Brazil likewise record a general regional Albian unconformity followed by a late Cenomanian transgressive cycle (Asmus and Ponte, 1973). Similar stratigraphic conditions are found in several of the western marginal basins of Africa such as the Gabon and Bas-Congo-Cabinda basins (Franks and Nairn, 1973). On the southeastern side of Africa several prominent unconformities and transgressive units are present in the Cenomanian to Campanian (Lambert, 1971; Sigal, 1974). On Madagascar this interval is characterized by a series of interfingering marine and continental units and two basalt flows (Sigal, 1974).

Associated with the eustatic changes were periods of increased terrigenous input and downslope transport during the Cenomanian to Santonian interval. Of particular interest is the influx of Inoceramus prisms in the Cenomanian and Santonian of Hole 327A, the Santonian to Coniacian of Site 357, and the Cenomanian and Santonian of the Magallanes Basin (Natland et al., 1974). At Site 260, a mixture of foraminiferal species indicates periods of reworking during the AlbianCenomanian, the Cenomanian, and possibly the Turonian-Coniacian (Krasheninnikov, 1974).

Mid-Cretaceous eustasy affected the rate of sediment supply and the deposition of carbonates in both epicon- tinental or deep-sea areas. Thus during transgressions, deep-sea sediment rates were reduced and carbonates were accumulated in shallow-water areas. These conditions and their associated effects led to increased dissolution in the ocean basins and raised the global CCS.

Cretaceous paleotemperatures from Europe and the North Pacific in general are similar in pattern (Figure 11). The curves for European belemnites (Spaeth et al., 1971) and North Pacific nannofossils (Douglas and Savin, 1975) show a period of steadily increasing temperature that extended from the Aptian to the Albian. Paleotemperatures then appear to fluctuate in the late Albian-Cenomanian and cooled during the Late Cretaceous following a second thermal maximum in the Coniacian-Santonian. The curve for North Pacific carbonate sediments (Coplen and Schlanger, 1973) differs significantly; nevertheless, it too shows the AptianAlbian increase and the Late Cretaceous thermal deterioration. One point made by these curves is the paucity of fossiliferous material or sediment available for the interval between the Cenomanian and Santonian, a situation similar to that in the southern hemisphere. The curve for New Zealand belemnites (Stevens and Clayton, 1971) is shown because it records lower paleotemperatures prior to the Coniacian that the authors attribute to the more southern paleogeographic position of New Zealand. These early New Zealand paleotemperatures define the apparent thermal gradient that existed between the Tethyan and Austral faunal provinces, a gradient of about $10^{\circ} \mathrm{C}$ or approximately half that of the present surface gradient as earlier suggested by Douglas and Sliter (1966).

The fluctuations of paleotemperature following the mid-Cretaceous thermal maximum produced periods of cooling and increased storminess. During climatic cooling, oceanic circulation was intensified, and the productivity of carbonate-producing microorganisms in extratropical latitudes was probably reduced. The combined results would increase dissolution and raise the CCS.

In summary, a series of tectonic and paleoclimatic events during the mid-Cretaceous combined to alter ocean basin symmetry, intensify the flow of cooler bottom water, increase dissolution, and raise the CCS. Cycles of dissolution intensity certainly took place more than once during the Cenomanian to Santonian hiatus, but the net result was the removal or nondeposition of carbonate material observed in the southern hemisphere DSDP sites.

A further consequence of these events was the profound alteration of the marine biota (Sliter, 1972). The Cenomanian-Turonian saw a rapid turnover second only to that at the end of the Mesozoic followed by a burst of diversification during the Turonian. Marine populations that had been cosmopolitan in nature in the poorly stratified Albian ocean basins increased in provincialism through the early Senonian as environmental stability and nutrient supplies were altered.

\section{Campanian-Maestrichtian Foraminiferal Provinces}

The geographic distribution of CampanianMaestrichtian foraminiferal assemblages from the southern hemisphere define three major faunal 
EUSTATIC CHANGES OF SEA-LEVEL

World.Continental Area Covered by Sea

$$
10^{6} \mathrm{Km}^{2}
$$

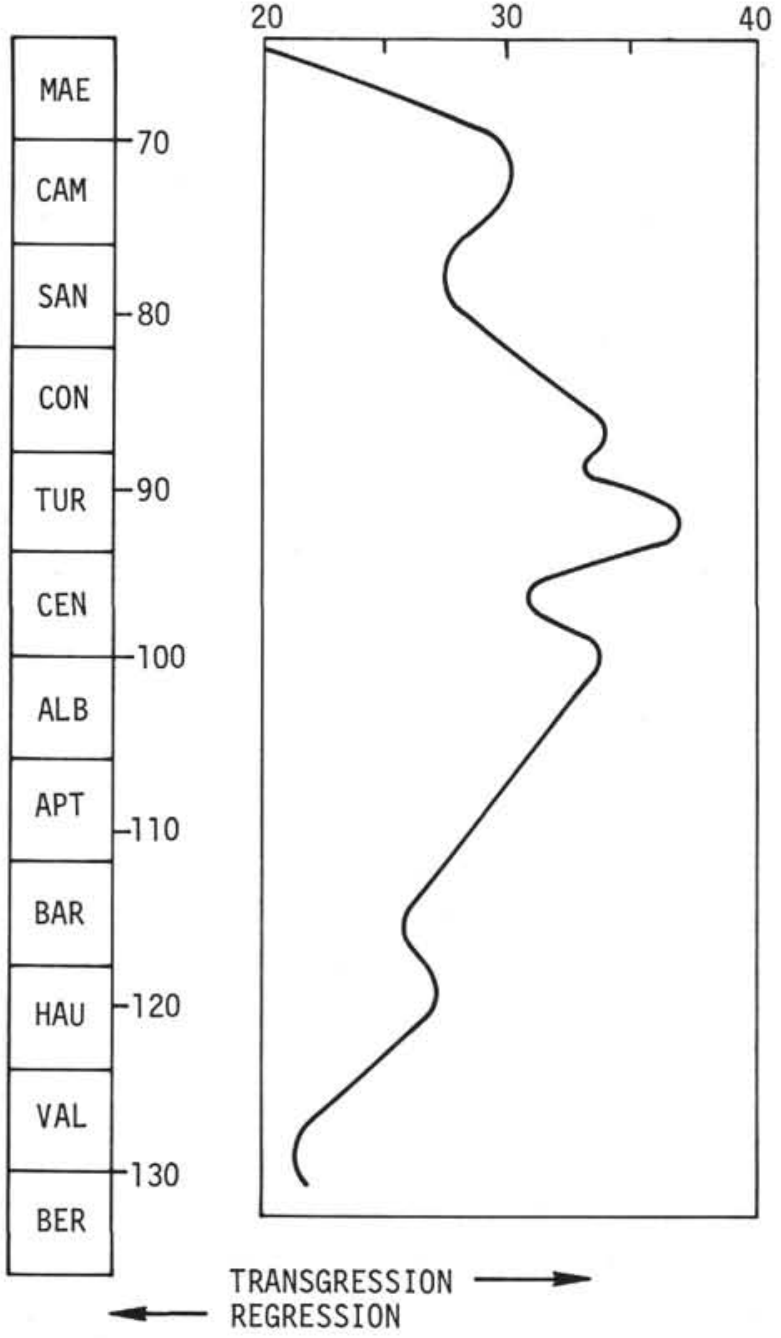

ISOTOPIC

PALEOTEMPERATURES ${ }^{\circ} \mathrm{C}$

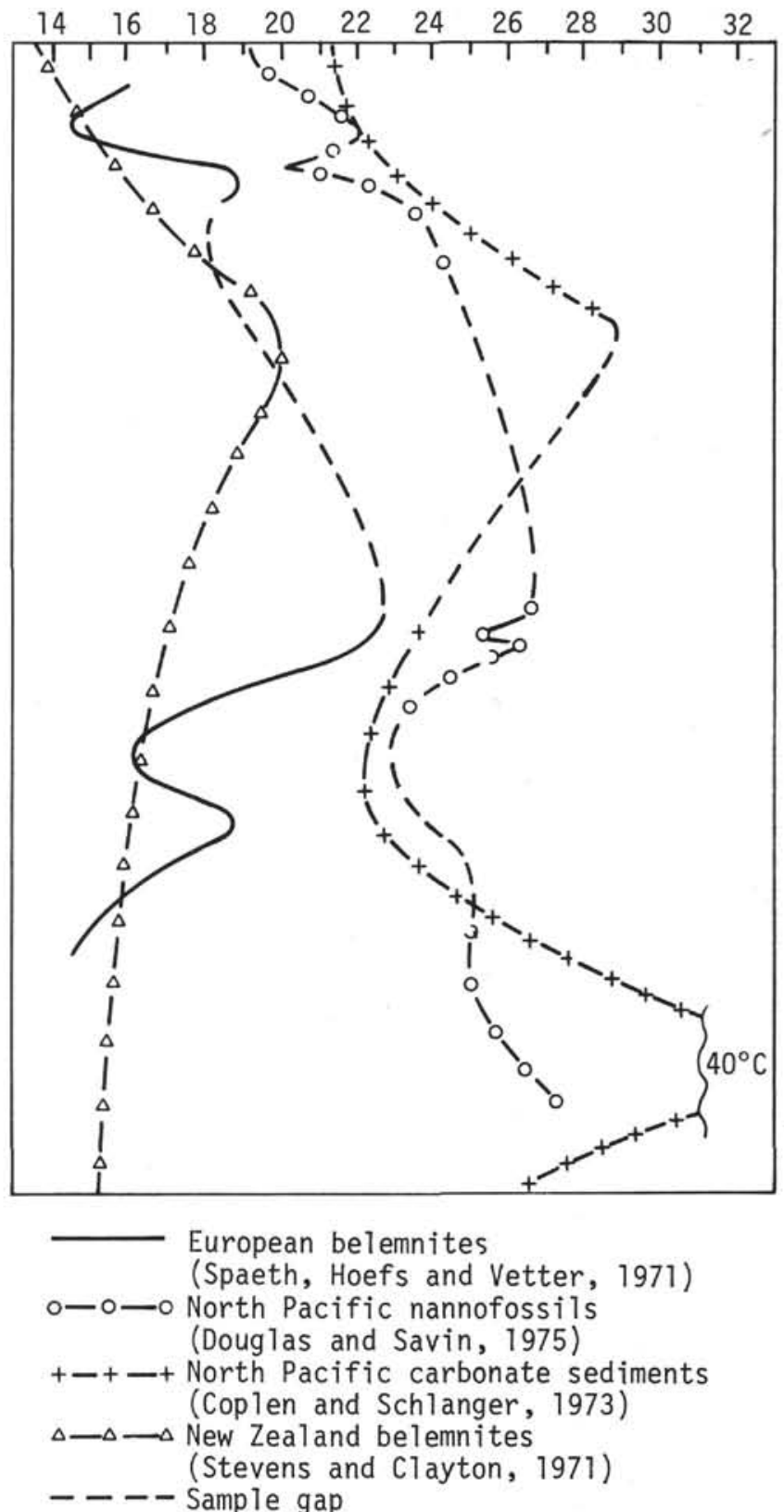

Figure 11. Cretaceous eustatic changes of sea-level and oxygen-isotope paleotemperature curves. Eustatic curve modified from Holmes (1964) and Rona (1973).

provinces: Tethyan, Transitional, and Austral (Figure 10). Planktonic species used to define these provinces are shown in Figure 12. This provincial scheme represents the analog to that described earlier from the eastern North Pacific (Sliter, 1972).

Tethyan assemblages are represented by the greatest diversity of planktonic species. All the single- and double-keeled globotruncanids are represented as well as the full range of the Heterohelicidae including species of Pseudotextularia, Racemiguembelina, Planoglobulina, Pseudoguembelina, Guembelitria, Heterohelix, and Gublerina. Species of Plummerita and
Trinitella appear to be restricted to the Tethyan province as are several globotruncanids.

The Transitional province is dominated by globotruncanids and heterohelicids; however, their relative abundance tends to decrease. Restricted Tethyan species are missing. Rugoglobigerines increase in abundance, and heterohelicid diversity is distinctly less than in the Tethyan province.

Austral faunas are dominated by rugoglobigerines, hedbergellids, and heterohelicids. Diversity is low, but the number of individuals may remain high. Species of Globotruncana and Globotruncanella represent a minor 
PROVINCE

SPECIES

TETHYAN TRANSITIONAL

Rugoglobigerina pilula

R. pustulata

R. rotundata

Heterohelix glabrans

H. globulosa

H. pulchra

Globigerinelloides multispinatus

Globotmuncana area

Globotruncanella havanensis

Hedbergella holmdelensis

H. monmouthensis

Planoglobulina carseyae

Schackoina multispinata

Abathomphalus intermedia

A. mayaroensis

Guembelitria cretacea

Globotmuncana marginata

Heterohelix striata

Rugoglobigerina macrocephala

R. rugosa

GLobotmuncana contusa

G. elevata

G. formicata

G. Zinneiana

G. mariei

G. stuarti

G. stuartiformis

G. ventricosa

Gublerina cuvillieri

Pseudotextularia elegans

Racemiguembelina fructicosa

Globotruncana aegyptiaca

Pseudoguembelina spp.

Rugotmuncana subcircumnodifer

Globotruncana calcarata

G. gansseri

Plummerita spp.

Rugoglobigerina scotti

Trinitella spp.

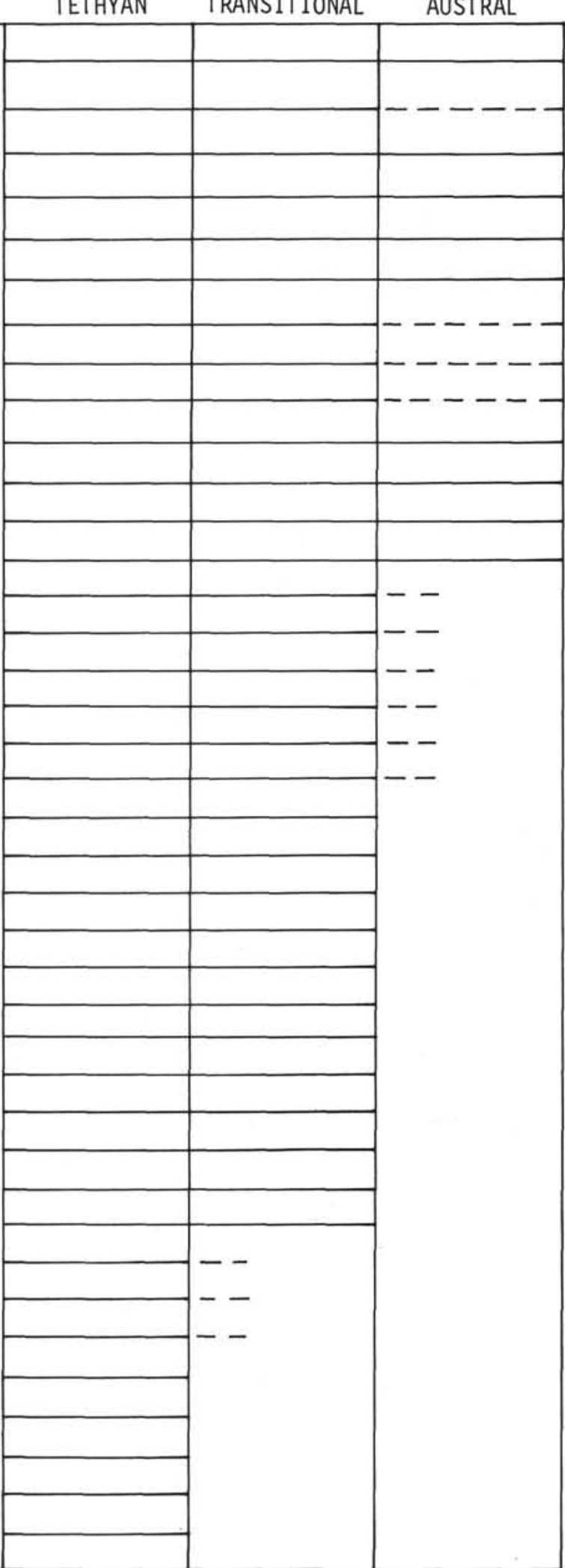

- - Rare

Figure 12. Provincial distribution of Late Cretaceous planktonic foraminifers in the southern hemisphere. 
but persistent component and Abathomphalus and Guembelitria may be present.

The provincial character of the CampanianMaestrichtian foraminiferal assemblages from DSDP sites and other occurrences in the southern hemisphere are shown in Figure 13. Figure 14 shows the geographic features discussed below. Tethyan assemblages tend to be between $0^{\circ}$ and $30^{\circ} \mathrm{S}$ latitude on the paleogeographic reconstruction taken from McKenzie and Sclater (1971) and Smith and Hallam (1970). Localities with assemblages that have Austral affinities are found on or adjacent to the Falkland Plateau and in New
Zealand. Several other localities are of particular interest. In the South Atlantic, the Maestrichtian foraminiferal assemblage from the Walvis Ridge reported by Todd (1968) is Transitional in character as evidenced by the presence of Heterohelix, Pseudoguembelina, Gublerina, Pseudotextularia, Planoglobulina, Racemiguembelina, Rugoglobigerina, Globotruncanella, and species of Globotruncana including G. arca. Site 249 off South Africa contains an interesting combination of Transitional and Tethyan species. The fauna contains Racemiguembelina, Abathomphalus, and rare Trinitella with Globotruncana contusa and G. stuarti. No Globo-

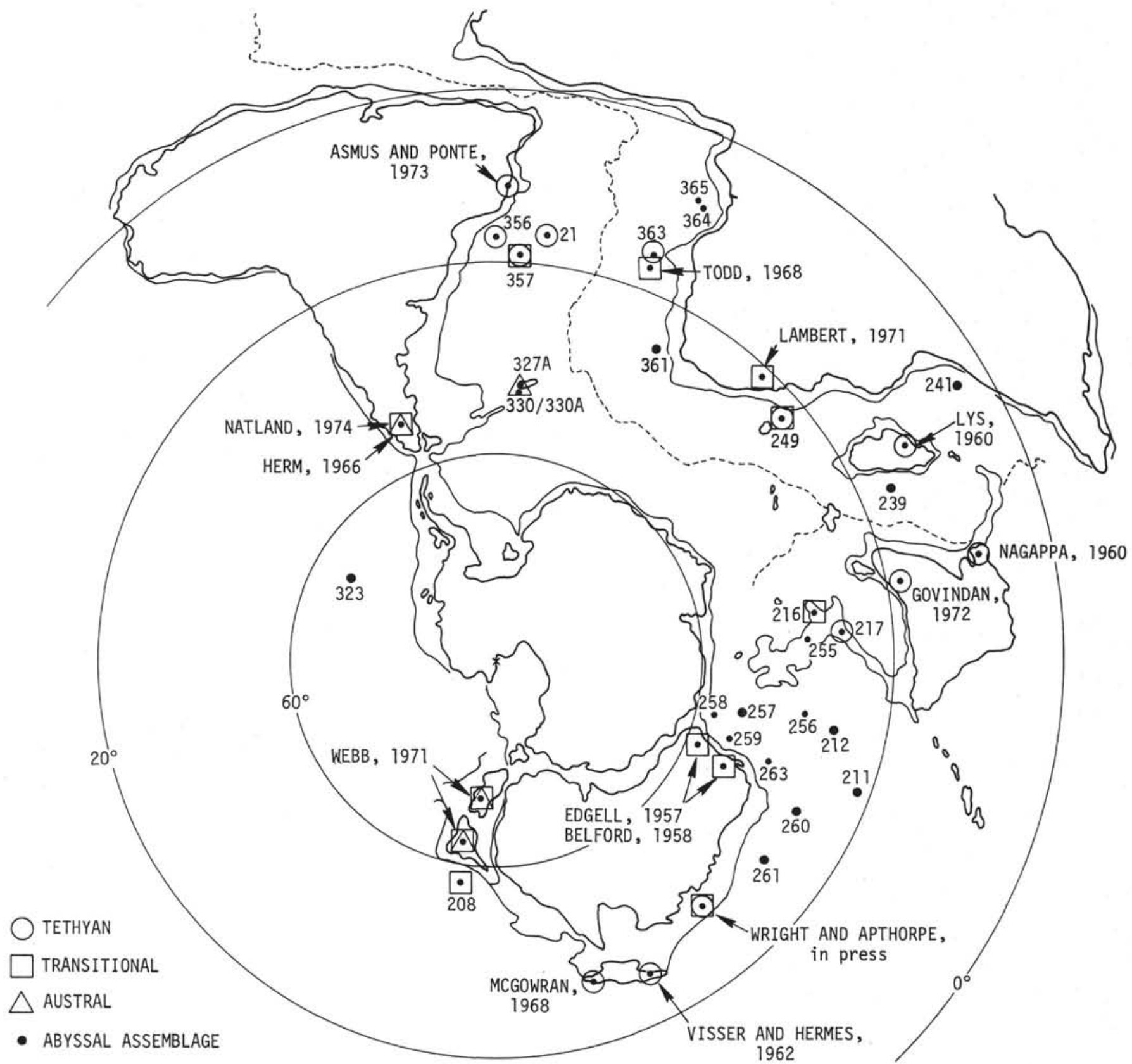

Figure 13. Paleogeographic distribution of Campanian-Maestrichtian faunal provinces and abyssal assemblages based on foraminifers from selected localities in the southern Hemisphere. Reconstruction based on McKenzie and Sclater (1971) and Smith and Hallam (1970). 


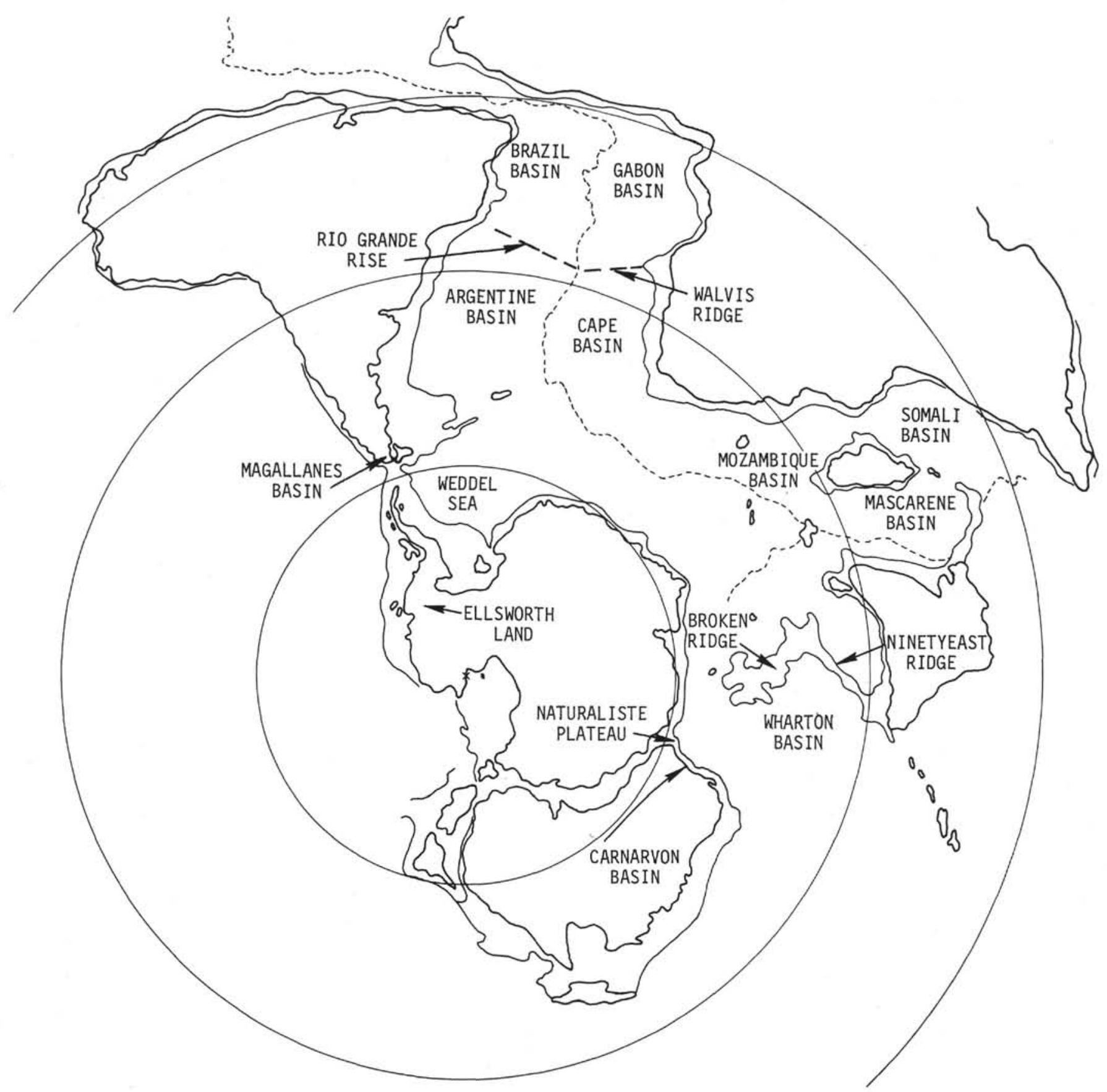

Figure 14. Selected geographic features plotted on the Late Cretaceous reconstruction.

truncana gansseri were recovered. Site 217 on Ninetyeast Ridge in the Indian Ocean contains a Tethyan assemblage of diverse double- and single-keeled globotruncanids and heterohelicids (McGowran, 1974). Globotruncana gansseri, however, is missing. Site 216, also located on Ninetyeast Ridge to the south of Site 217 , contains a Transitional assemblage characterized by lower diversity, a poorly developed Globotruncana stuarti group, fewer heterohelicids and the absence of the G. aegyptiaca group (Gartner et al., 1974). In the Carnarvon Basin of Western Australia, foraminiferal assemblages from the Miria Marl show a Transitional influence in the absence of the $G$. aegyptiaca group and several Tethyan species of single-keeled globotruncanids, heterohelicids, and Rugoglobigerina (Edgell, 1957; Belford, 1958).

The foraminiferal assemblage from the northwest shelf of Western Australia described by Wright and Apthorpe (in press) is distinctly more Tethyan as evidenced by the presence of Globotruncana stuarti and rare G. aegyptiaca; however, G. gansseri still is missing.

In contrast, assemblages from New Zealand and the Magallanes Basin of southernmost South America have a definite Austral character. New Zealand planktonics consist of Hedbergella, Heterohelix, Rugoglobigerina, Rugotruncana, Abathomphalus, Guembelitria, 
Gublerina, and Globigerinelloides (Webb, 1971), whereas the South American assemblages are restricted to Heterohelix, Hedbergella, and Globotruncana (Natland et al., 1974).

The faunal provinces are defined by foraminiferal assemblages typically from ocean ridges, plateaus, or continental margin outcrops (see Figures 13 and 10). The DSDP sites involved generally are from localities whose present water depths are 3000 meters or less. Paleobathymetric interpretations from these assemblages indicate a similar depth range. In contrast, DSDP sites from ocean basins (greater than $4000 \mathrm{~m}$ ) are characterized by sparse foraminiferal assemblages composed predominantly of indigenous agglutinated and less abundant resistant calcareous species with occasional admixtures of transported planktonic and benthonic species preserved in isolated layers. The distribution of these abyssal assemblages is shown on Figures 10 and 13. Redeposited planktonic species preserved in the deep-sea sediments generally reflect the regional foraminiferal province such as those at Sites 260 and 361. Planktonic species in these deposits tend to be mechanically sorted and usually consist of small specimens of Heterohelix, Hedbergella, and Globigerinelloides with few globotruncanids or larger genera. Transported benthonics also are generally size sorted similar to those in distal-fan deposits. From the paleobathymetric distribution of the provincial and abyssal assemblages it would appear that the Late Cretaceous foraminiferal lysocline and the CCS in these southern hemisphere sites ranged between 3000 and 4000 meters.

Distribution of the Late Cretaceous foraminiferal provinces resulted primarily from oceanic circulation patterns and gyre configurations. To examine these faunal provinces and circulation patterns, two Cretaceous paleogeographic reconstructions of the eastern Falkland Plateau are employed: (1) The generally assumed position of the Leg 36 sites to the east of the Falkland Islands and Falkland Plateau proper, and (2) a Mesozoic position adjacent to the Antarctic Peninsula and the Magallanes Basin of South America. Given the first reconstruction, the following circulation patterns are suggested to have been largely responsible for the observed provincial distribution. A dominant westward-flowing North Equatorial Current circled the globe north of the equator (Figure 15). This tropical current formed the core of the Tethyan province. In the southern hemisphere, an easterly flowing circumpolar current circled Antarctica, Australia, and New Zealand. This West Wind Drift and the associated Subtropical Convergence and Antarctic Convergence were depressed further southward than at present even though the thermal gradient was intensified over mid-Cretaceous conditions.

Within the South Atlantic, two gyres may have existed: a southern gyre in the Cape and Argentine basins influenced by the cool Benguela and Falkland Currents and a warm Agulhas Current, and a northern gyre in the Gabon and Brazil basins flowing into the North Atlantic as the South Equatorial Current. The Falkland Plateau, Rio Grande Rise, and Walvis Ridge may have formed boundaries for the gyres even though their crests were depressed beneath sea level. The present
Benguela Current is deflected to the west by the Walvis Ridge. During the Late Cretaceous, this deflection should have been enhanced by the more elevated position of the ridge.

In the Indian Ocean, an intensified Mozambique Current fed tropical water into the southwest Indian Ocean where it mixed with the West Wind Drift. The drift circled northern Australia where it combined with the warm East Australian Current. In the South Pacific, the West Wind Drift diverged to flow both north along western South America and into the South Atlantic through the Antarctic Peninsula and perhaps through a trench to the east of Ellsworth Land.

Several problems arise by using the generally assumed position of the eastern Falkland Plateau. The Austral character of the foraminiferal fauna contrasts with other faunas from the South Atlantic. As shown on Figure 15, the proposed oceanic circulation patterns can be used to explain the cool-water aspects of the eastern Falkland Plateau sites. However, one wonders if the circulation pattern could produce the taxonomic isolation of these sites within the South Atlantic-Indian Ocean region characterized by Tethyan and Transitional faunas. Serious questions are raised as to whether the volume of ocean flow through the incipient Drake Passage or a trough across western Antarctica, was enough to maintain the Austral character of the Leg 36 sites. Further, the late Albian-Cenomanian submergence history of the Magallanes Basin is strikingly similar to that of the eastern Falkland Plateau (Natland et al., 1974) suggesting a tectonic relationship between the two areas. Paleobathymetric interpretation based on foraminifers for this submergence are nearly identical to those for Hole 327A. This brings us to the second hypothesis, that the Cretaceous position of the eastern Falkland Plateau was adjacent to the Magallanes Basin (Figure 16). Following this explanation the Austral faunas of the Leg 36 sites would thus be aligned with similar faunas in South America and New Zealand. Movement of the eastern Falkland Plateau to its present position would have occurred during latest Cretaceous or Cenozoic time. This explanation is in agreement with Jurassic and Albian megafossil data which suggest a similar paleogeographic reconstruction (Jones and Plafker, this volume).

Accordingly, the circulation patterns shown in Figure 15 would be modified by reducing the West Wind Drift through the Antarctic Peninsula region and consequently increasing the influence of the tropical water flowing into the western Indian Ocean and South Atlantic Ocean. The major circulation patterns in the South Atlantic and Indian oceans would remain essentially unchanged. Obviously, to answer these questions concerning the Cretaceous and earlier position of the eastern Falkland Plateau more paleontological and geophysical exploration must be made in the Falkland Plateau region and in areas adjacent to the Antarctic continent.

Late Cretaceous bottom currents represent a largely unknown entity. However, the presence of strongly corroded abyssal assemblages during the Late Cretaceous indicates that the formation of these corrosive waters 


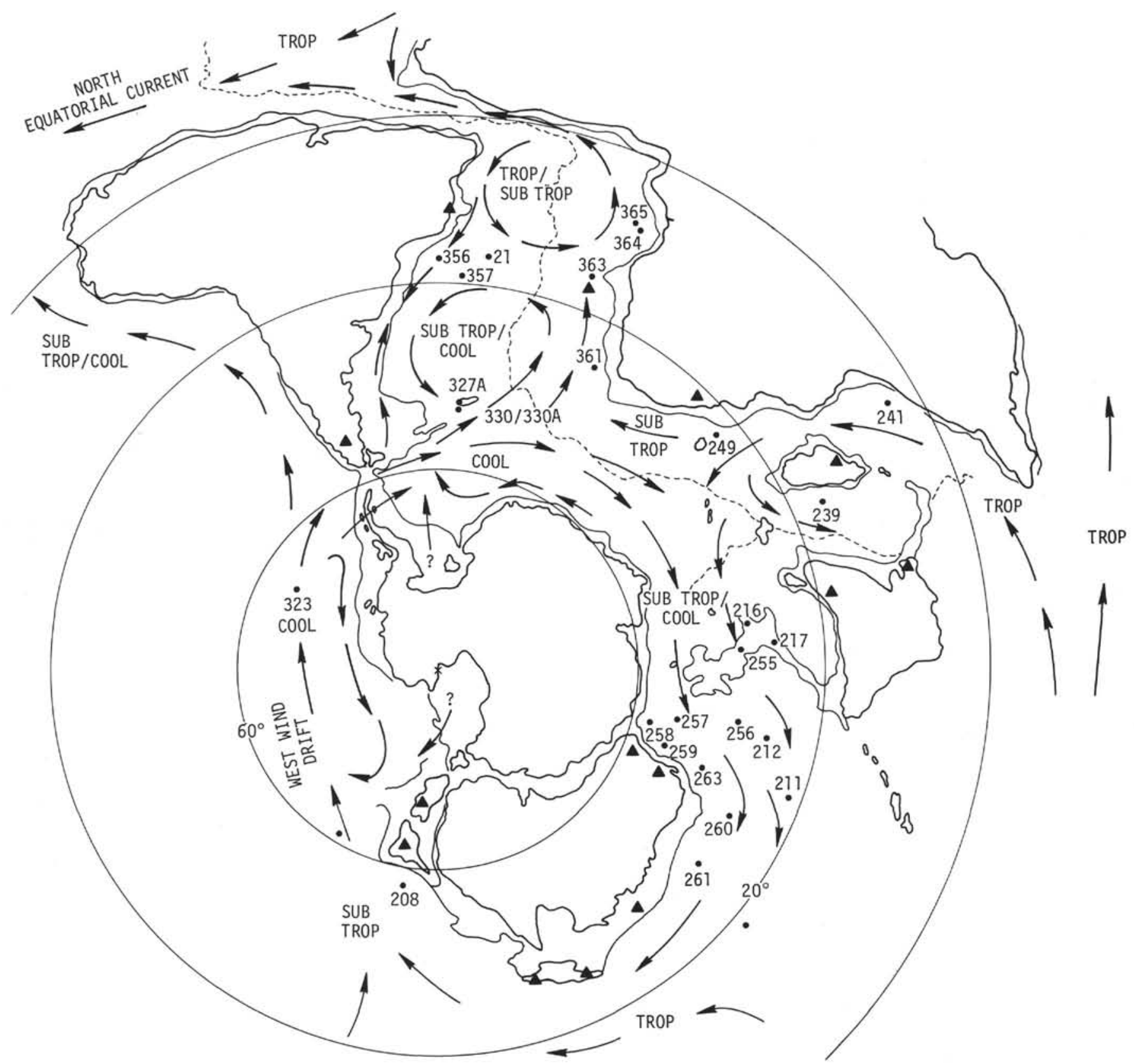

Figure 15. Inferred Campanian-Maestrichtian surface currents for the southern hemisphere.

was begun or strongly enhanced during the midCretaceous. Certainly, as the thermal gradient and ocean stratification intensified during the Late Cretaceous, both the flow and the aggressiveness of the bottom water increased.

Bottom water in the South Atlantic presumably formed in the Weddell Sea and flowed north into both the South Atlantic and Indian oceans (Figure 17). Flow into the Argentine Basin was accomplished through the Falkland Island fracture zone or through fracture zones in the Mid-Atlantic Ridge (Sclater and McKenzie, 1973). Some flow may have entered the Brazil Basin through the Rio Grande gap during latest Cretaceous as the rise continued to subside (Perch-Nielsen et al., 1975).
In the eastern South Atlantic, bottom water flowed through fracture zones or gaps in the Antarctic-Indian Ridge into the Cape Basin. Access to the Gabon Basin by deep-water masses was apparently established by the Late Cretaceous (Bolli et al., 1975).

Bottom water in the western Indian Ocean flowed north by way of the Mozambique, Mascarene, and Somali basins. In the southern Indian Ocean, bottom flow continued around Antarctica and into the Wharton Basin by way of a gap between Broken Ridge and Naturaliste Plateau. The Late Cretaceous hiatus noticed earlier in abyssal plain sediments of the Wharton Basin (see Figure 10) is thought to have resulted from nondeposition due to bottom currents. This increase in bottom flow presumably resulted from both the open- 


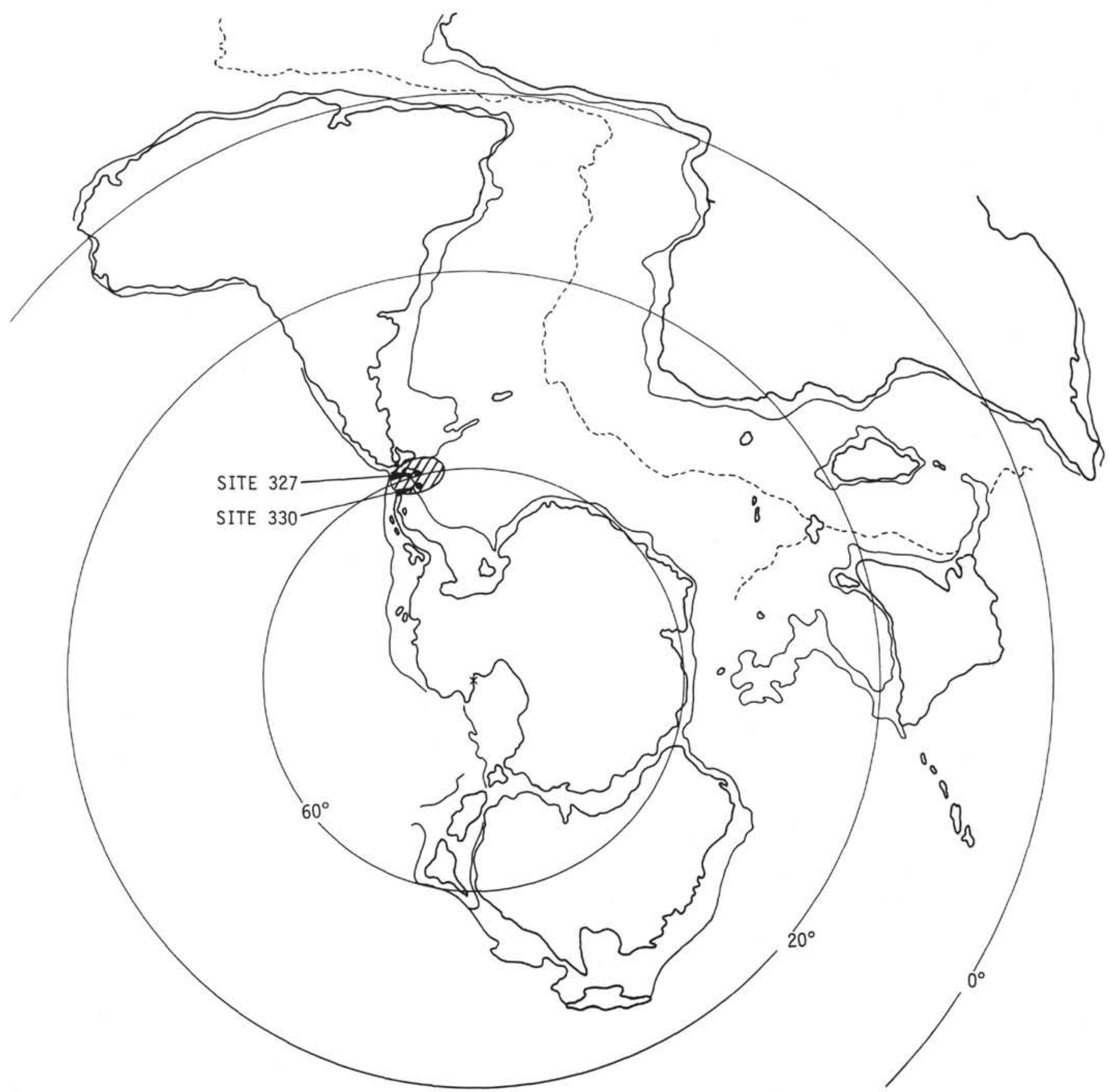

Figure 16. Postulated Late Cretaceous position of the eastern Falkland Plateau and Sites 327 and 330.

ing of the Broken Ridge gap and the continued deterioration of the climate.

\section{CONCLUSIONS}

1. Albian to Maestrichtian foraminiferal faunas from Leg 36 are Austral or cool water in character. Planktonic faunas are typically low diversity, and most of the Tethyan stratigraphic indicator species are absent.

2. Paleoenvironments ranged from 100 to 400 meters during the Albian to 1500-2500 meters during the Campanian-Maestrichtian. Pronounced subsidence of the eastern Falkland Plateau occurred in the latest
Albian-Cenomanian and followed a period of relative stability throughout most of the Albian. This subsidence, also recognized in the Magallanes Basin, probably corresponded to tectonic activity in the southern Andean Cordillera. Santonian foraminifers are indicative of abyssal water depths greater than 2500 meters. A complex tectonic history of subsidence and uplift is required to explain these faunas. Alternatively, the assemblage may indicate the upward migration of the abyssal fauna as hydrographic conditions were altered during the mid-Cretaceous.

3. Aptian-Albian foraminiferal faunas in the higher southern latitudes show a similarity in Austral 


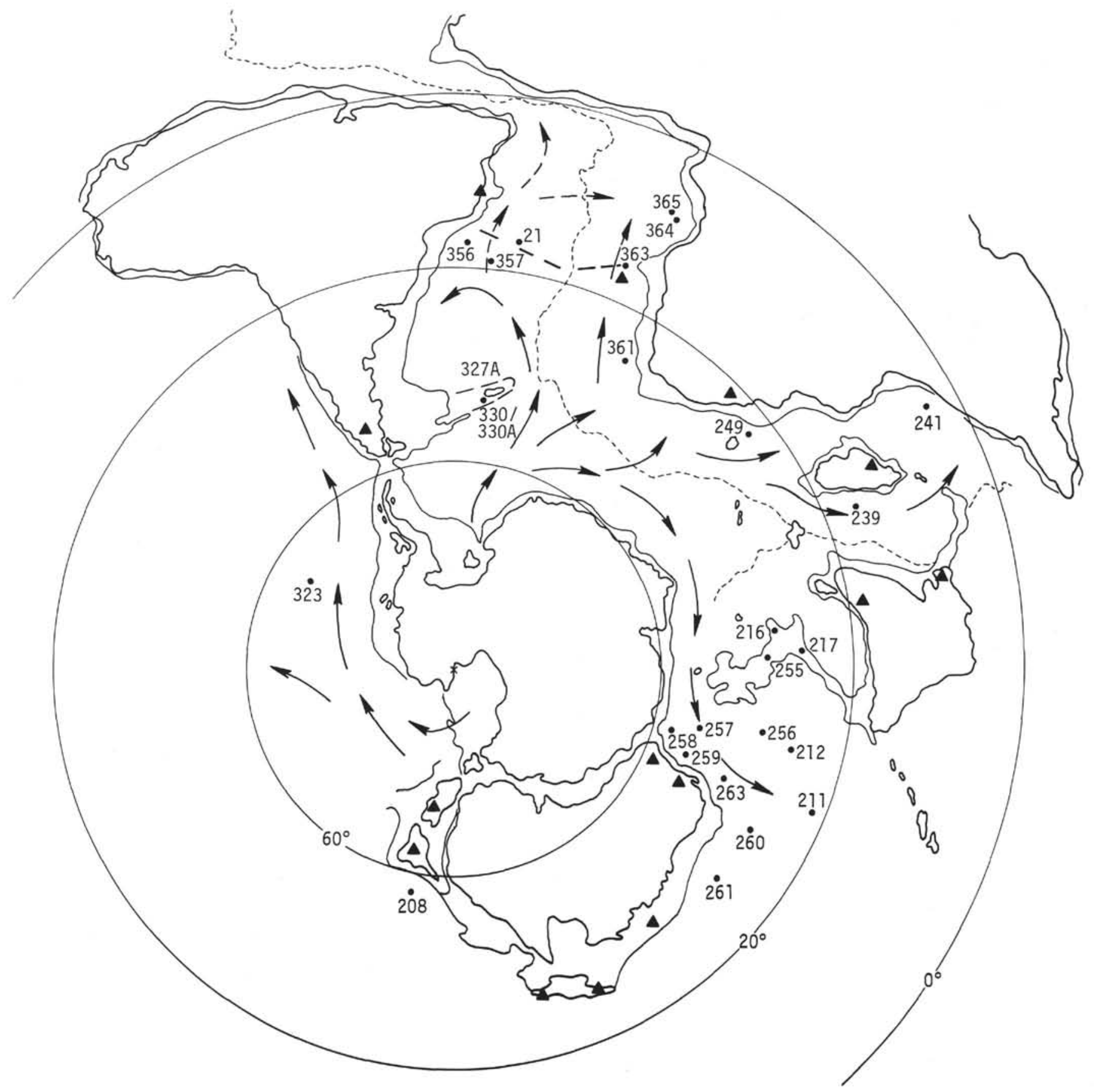

Figure 17. Suggested Campanian-Maestrichtian bottom currents in the southern hemisphere.

character. This similarity is due to a number of interrelated factors that include a cooler extratropical temperature for the high-latitude sites, the reduced size of the South Atlantic and southern Indian Oceans, restricted oceanic exchange, and isolation from Tethyan faunas. Common Aptian-Albian sapropelic sediments and warm isotopic paleotemperatures indicate that many of the world's oceans were poorly stratified with perhaps an expanded oxygen-minimum zone. The reduced latitudinal thermal gradient and the corresponding reduction in oceanic thermal stratification contributed to the regional development of the Austral fauna and makes difficult the bathymetric in- terpretation of Aptian-Albian deep-water foraminiferal assemblages.

4. The regional mid-Cretaceous hiatus recognized in many southern hemisphere DSDP sites and onshore sections corresponds to a time of eustatic changes in sea level, fluctuations in paleotemperature, and tectonic events that combined to produce periods of intensified ocean bottom currents and carbonate dissolution. A circum-Antarctic/Australian surface current may have initially developed at this time.

5. Late Cretaceous foraminiferal faunas show increased provinciality related to the intensified thermal gradient, the pattern of oceanic circulation, and the 
depth of the CCS. As a result, three foraminiferal provinces are recognized in the southern hemisphere: Tethyan, Transitional, and Austral. Deep-water assemblages indicate that the Late Cretaceous foraminiferal lysocline and the CCS in the southern hemisphere ranged between 3000 and 4000 meters.

6 . The Leg 36 foraminiferal faunas closely resemble faunas in South America and New Zealand. This similarity can be explained by the pattern of oceanic circulation. However, based on the Austral character of the faunas and the late Albian-Cenomanian subsidence history, the possibility remains that the eastern Falkland Plateau may have occupied a paleogeographic position adjacent to Patagonia and the Antarctic Peninsula and that migration to its present position was accomplished during the Cenozoic development of the Scotian Arc.

\section{TAXONOMIC NOTES}

\section{Genus HETEROHELIX Ehrenberg, 1843}

\section{Heterohelix glabrans (Cushman)}

(Plate 7, Figure 1)

Recognized by the slightly keeled early portion of the test, fine perforations and smooth, polished surface, this species first occurs in the late Campanian samples and becomes increasingly common in the Maestrichtian interval of Hole 327A

\section{Heterohelix globulosa (Ehrenberg)}

(Plate 6, Figures 4-6)

This small species with globular chambers represents a minor constituent of the Santonian to Maestrichtian samples of Hole 327A.

\section{Heterohelix pulchra (Brotzen}

(Plate 6, Figures 7-9)

A small species characterized by reniform-shaped ultimate chambers, compressed test, and apertural flanges. It occurs consistently in the Campanian-Maestrichtian samples of Hole 327A.

\section{Heterohelix reussi (Cushman}

(Plate 7, Figures 2, 3)

Small specimens with globular chambers, a flaring test and fine costae are assigned to this species. As noted by Pessagno (1967), the type specimens show fine costae although Cushman described the surface as smooth. Rare, poorly preserved specimens are restricted to Santonian samples of Hole 327A.

\section{Genus PLANOGLOBULINA Cushman, 1927 \\ Planoglobulina carseyae (Plummer) \\ (Plate 7, Figures 4-6)}

Test large, compressed, initially biserial, later adding chambers in the biserial plane or becoming irregular, surface finely costate. The species occurs throughout the Campanian-Maestrichtian samples of Hole 327A. Most specimens represent the early biserial stage (Plate 7, Figure 5) but specimens with additional chambers (Plate 7, Figure 6) occur in many samples.

\section{Genus GLOBIGERINELLOIDES Cushman and ten Dam, 1948}

\section{Globigerinelloides bentonensis (Morrow)}

(Plate 5, Figures 4, 5)

Very rare specimens of this species with an inflated test, broadly rounded periphery and 6 to 7 chambers occur in the Albian of Hole $327 \mathrm{~A}$.

\section{Globigerinelloides caseyi (Bolli, Loeblich, and Tappan)}

(Plate 5, Figures 3, 6)

Rare, small, compressed specimens with 6 to 7 chambers are assigned to this species. Occurrences are limited to the Albian of Hole $327 \mathrm{~A}$.

\section{Globigerinelloides gyroidinaeformis Moullade} (Plate 3, Figures 8, 9)

Large specimens with 4 to 5 globular chambers, a broadly rounded periphery and involute test are tentatively assigned to this species. Future studies may assign this species to the Cassidulinacea, however it is retained here under the present genus until the taxonomic confusion is resolved. The rarely occurring specimens are restricted to the early Albian of Hole $327 \mathrm{~A}$.

\section{Globigerinelloides multispinatus (Lalicker)}

(Plate 5, Figures 7-9)

A small test with globular chambers, finely hispid surface, and rare double apertures (Plate 5, Figure 9) characterize this species. Specimens are found rarely in the Campanian-Maestrichtian samples of Hole 327A.

Globigerinelloides impensus Sliter, n. sp. (Plate 6, Figures 1-3)

Test free, planispiral, biumbilicate, partially evolute, equatorial periphery lobate, axial periphery rounded. Chambers 8 to 10 in final whorl, equatorially flattened, increasing gradually in size, final chambers generally ovate, ultimate chamber often reduced in size. Sutures distinct, depressed radial, straight to gently curved. Wall calcareous, finely perforate, surface pustulose on early chambers of final whorl, final few chambers nearly smooth. Aperture a broad, low, interiomarginal, equatorial arch, bordered above by a narrow lip. Relic apertures and relic apertural flaps distinct.

Largest diameter of holotype: $0.32 \mathrm{~mm}$. Paratypes range from 0.28 to $0.43 \mathrm{~mm}$.

Locality: Holotype and paratypes from Leg 36, Sample 327A-13-2, $61-63 \mathrm{~cm}$. Falkland Plateau, South Atlantic Ocean (lat $50^{\circ} 52.28^{\prime} \mathrm{S}$, long $46^{\circ} 47.02^{\prime} \mathrm{W}$ ).

Type horizon: Late Campanian.

Remarks: This large planktonic species characterized by the numerous flattened chambers occurs consistently in the late Campanian samples of Leg 36. Globigerinelloides impensus $\mathrm{n}$. sp. somewhat resembles G. alvarezi (Eternod Olvera) originally described from the Campanian-Maestrichtian of Mexico. It differs, however, in the larger size, compressed test, slightly curved sutures, and less highly arched aperture.

The new species differs from Globigerinelloides bollii Pessagno in its larger size, more numerous, more compressed chambers, gently curved sutures, and pustulose surface.

Holotype and figured paratypes are deposited in the U.S. National Museum of Natural History, Washington, D.C.

\section{Genus SCHACKOINA Thalmann, 1932}

Schackoina cenomana (Schacko)

(Plate 7, Figure 7)

Rare, poorly preserved specimens with peripheral tubulospines were found in the Cenomanian of Hole $327 \mathrm{~A}$ and the Albian/Cenomanian of Hole 330A.

\section{Schackoina multispinata (Cushman and Wickenden) \\ (Plate 7, Figures 8, 9)}

This small, low trochospiral species with irregularly distributed tubulospines occurs in Campanian-Maestrichtian samples of Hole 327A.

\section{Genus HEDBERGELLA Brönniman and Brown, 1958}

\section{Hedbergella amabilis Loeblich and Tappan}

(Plate 1, Figures 1-4)

A small, distinctive species with a compressed test, 5 to 6 chambers that become increasingly elongate and a lobate periphery. The species occurs in Albian-Cenomanian samples of Holes 327A, 330, and $330 \mathrm{~A}$. 


\section{Hedbergella delrioensis (Carsey)}

(Plate 1, Figures 5-9)

This is a common species throughout the Albian-Cenomanian of Holes $327 \mathrm{~A}, 330$, and $330 \mathrm{~A}$ with rare occurrences in the Santonian of Hole $327 \mathrm{~A}$. It is characterized by globular, inflated chambers generally 5 in number, a flattened spiral surface, and a large, arched aperture. Specimens tend to intergrade with Hedbergella infracretacea (Glaessner), but the two species are here considered distinct.

\section{Hedbergella holmdelensis Olsson}

(Plate 2, Figures 1-4)

Specimens referred to this species are small, compressed with spiral and umbilical sides nearly flat, 5 to 7 globular chambers that increase moderately in size, and a smooth to finely hispid wall. The small specimens represent a rare constituent of the CampanianMaestrichtian samples of Hole 327A.

\section{Hedbergella infracretacea (Glaessner) \\ (Plate 2, Figures 5-8)}

This species is recognized by small, distinctly compressed test, reniform to oval-shaped chambers generally 5 in the last whorl and a lobate periphery. It represents a consistent member of the Albian assemblages at Holes 327A and 330 and the Albian/Cenomanian samples of Hole $330 \mathrm{~A}$.

\section{Hedbergella monmouthensis (Olsson)}

(Plate 3, Figures 1-3)

The flattened spiral side, inflated chambers generally 5 in the last whorl, arched aperture, and pustulose surface characterize this species. It ranges throughout the Campanian-Maestrichtian samples of Hole 327A, but becomes more abundant in the Maestrichtian section.

\section{Hedbergella planispira (Tappan)}

(Plate 3, Figures 4-7)

This minute, compressed, nearly planispiral species with 6 to 7 chambers in the final whorl that increase gradually in size represents the most abundant species in the Albian to Cenomanian samples of Holes 327A, 330, and 330A. Hedbergella planispira also occurs rarely in the Santonian of Hole 327A.

\section{Hedbergella portsdownensis (Williams-Mitchell)}

(Plate 4, Figures 1-5)

This species is recognized by its medium to high trochospiral test, 5 to 6 globular chambers in the final whorl, hispid surface, and lobate periphery. Secondary apertures on the spiral surface of the final chamber are observed occasionally in specimens from the late Albian of Hole 327A (see Plate 4, Figures 4 and 5). Hedbergella brittonensis Loeblich and Tappan is considered a junior synonym of $H$. portsdownensis.

Hedbergella portsdownensis represents a consistent but minor component of the Albian and Cenomanian assemblages of Holes 327A, 330 , and $330 \mathrm{~A}$.

\section{Hedbergella sigali Moullade}

(Plate 4, Figures 6-8; Plate 5, Figures 1, 2)

Specimens referred to this species are small, low trochospiral with 4 chambers in the final whorl. Chambers are ovate in shape and increase rapidly in size. The ultimate chamber is variable in size, and the test is subquadrate in plan view with a pronounced lobate periphery. Occurrences are restricted to the early-middle Albian of Holes $327 \mathrm{~A}$ and 330 . The extension of this species, known from the Barremian and lower Aptian of France, into the Albian corresponds to a similar occurrence described by Herb (1964) from DSDP Site 256 in the eastern Indian Ocean.

\section{Genus PRAEGLOBOTRUNCANA Bermúdez, 1952}

\section{Praeglobotruncana delrioensis (Plummer)}

(Plate 8, Figures 1-3, 6)

Rare specimens of this species were found in the late AlbianCenomanian samples of Holes $327 \mathrm{~A}$ and $330 \mathrm{~A}$. At these sites the species is found just above and below the Albian/Cenomanian boundary. Specimens are identical to the specimen found by Herb (1964) from DSDP Site 258 and are identified by the coarsely spinose early periphery, compressed test, subglobular chambers, and prominent interiomarginal, extraumbilical-umbilical arch with a narrow bordering lip.

\section{Genus ROTALIPORA Brotzen, 1942}

\section{Rotalipora reicheli (Mornod) \\ (Plate 8, Figures 4, 5, 7)}

Very rare whole specimens and more numerous fragments of this species were recovered from the Cenomanian of Hole 327A. These specimens are characterized by a large test with a slightly convex spiral side, strongly inflated umbilical side, and narrow keeled periphery. Chambers are 6 to 7 in the final whorl and angulartruncate. The primary aperture is an interiomarginal, extraumbilicalumbilican arch, and the secondary apertures consist of a single, sutural opening on the umbilical side of each chamber. A single fragment of this species was recovered by Herb (1964) from the Cenomanian of DSDP Site 258 on the Naturaliste Plateau.

\section{Genus WHITEINELLA Pessagno, 1967}

Whiteinella baltica Douglas and Rankin

(Plate 8, Figures 8, 9; Plate 9, Figures 1, 2)

Identified by the low trochospiral test, lobate, and broadly rounded periphery, inflated chambers, coarsely hispid to pustulose surface, shallow umbilicus and extraumbilical-umbilical aperture, this cosmopolitan species occurs rarely in the Santonian of Hole 327A.

\section{Genus ARCHAEOGLOBIGERINA Pessagno, 1967}

\section{Archaeoglobigerina bosquensis Pessagno}

(Plate 9, Figures 3-5)

This species is distinguished by its large, globigerine test, 5 inflated chambers in the final whorl, moderately deep umbilicus, prominent umbilical aperture, and pustulose surface. Specimens are restricted to the Santonian of Hole 327A.

\section{Genus GLOBOTRUNCANA Cushman, 1967}

\section{Globotruncana arca (Cushman)}

(Plate 9, Figures 6, 7)

A single, small, poorly preserved specimen of this double-keeled species was found in the Maestrichtian of Hole 327A.

\section{Genus GLOBOTRUNCANELLA Reiss, 1957}

\section{Globotruncanella havanensis (Voorwijk)}

(Plate 10, Figures 1-6)

This widespread, cosmopolitan species is recognized by its biconvex test, 5 to 6 subglobular chambers in the final whorl, acute to sharply rounded periphery with a pustulose, imperforate band on the early chambers, small shallow umbilicus and apertural flaps that fuse to form tegilla with intra- and infralaminal accessory apertures.

Leg 36 specimens are limited to the Maestrichtian of Hole 327A.

Genus RUGOGLOBIGERINA Brönnimann, 1952

\section{Rugoglobigerina pilula Belford}

(Plate 10, Figures 7-9)

Rugoglobigerina pilula is the most abundant planktonic foraminifer in the Campanian samples of Hole 327A. The distinguishing characteristics include a spiroconvex test, globular inflated chambers that number 5 to 6 in the final whorl and increase gradually in size, rugose ornamentation arranged in a weak meridional pattern, small, deep umbilicus and a prominent interiomarginal, umbilical aperture often covered by tegilla.

The Leg 36 specimens are very similar to those found in northern California (Douglas, 1969) and Vancouver Island (Sliter, 1973). Rugoglobigerina tradinghousensis Pessagno appears to be a junior synonym of $\boldsymbol{R}$. pilula. 


\section{Rugoglobigerina pustulata Brönnimann}

(Plate 11, Figures 4-6)

Rare small specimens referred to this species were found in the Maestrichtian samples of Hole 327A. These specimens have a low trochospiral test with 5 to 6 subglobular chambers, pronounced pustulose ornamentation on the early chambers of the final whorl, and an umbilical aperture with tegilla.

\section{Rugoglobigerina rotundata Brönnimann} (Plate 11, Figures 1-3)

This large, subglobular species is the dominant planktonic foraminifer in Maestrichtian samples of Hole 327A. In addition to the characteristic shape, the species is distinguished by its 5-6 globular chambers in the final whorl that increase gradually in size, the large, open aperture and the surface pustules and rugae that are arranged in an indistinct meridional pattern.

Rugoglobigerina rotundata differs from $R$. pilula in its larger, more globular test, larger aperture, and somewhat more prominent umbilicus.

\section{ACKNOWLEDGMENTS}

I wish to thank P.F. Barker and I.W.D. Dalziel (Co-chief Scientists, Leg 36) for making available the material for this study. In addition, R.C. Tjalsma (Leg 36 paleontologist) brought the material to my attention and provided the necessary cruise information.

I am indebted to D.L. Jones and R.Z. Poore (U.S. Geological Survey, Menlo Park, California) for having kindly read and commented upon the manuscript. Particular thanks are due R.L. Oscarson for taking the scanning electron micrographs and to S.E. Murphy for her help in preparing the illustrations.

\section{REFERENCES}

Andrews, J.E., Packham, G., et al., 1976. Initial Reports of the Deep Sea Drilling Project, Volume 30: Washington (U.S. Government Printing Office).

Asmus, H.E. and Ponte, F.C., 1973. The Brazilian marginal basins. In Nairn, A.E.M. and Stehli, F.G. (Eds.), The ocean basins and margins: New York (Plenum Press), v. 1 , p. $87-133$

Belford, D.J., 1960. Upper Cretaceous foraminifera from the Toolonga Calcilutite and Gingin chalk, Western Australia: Australia Bur. Min. Res. Geol. Geophys. Bull., v. 57, p. 1-198.

Belford, D.J. and Scheibnerová, V., 1971. Turonian foraminifera from the Carnarvon Basin, Western Australia, and their palaeogeographical significance: Micropaleontology, v. 17, p. 331-344.

Berger, W.H. and Winterer, E.L., 1974. Plate stratigraphy and the fluctuating carbonate line. In Hsu, K.J. and Jenkyns, H.C. (Eds.), Pelagic sediments on land and under the sea: Internat. Assoc. Sedimentol. Spec. Pub. no. 1, p. 11-48.

Berggren, W.A. and Hollister, C.D., 1974. Paleogeography, paleobiogeography and the history of circulation in the Atlantic Ocean. In Hay, W.W. (Ed.), Studies in paleooceanography: Soc. Econ. Paleontol. Mineral. Spec. Pub. 20, p. 126-186.

Bolli, H.M., et al., 1975. Basins and margins of the eastern South Atlantic: Geotimes, p. 22-24

Burns, R.E., Andrews, J.E., et al., 1973. Initial Reports of the Deep Sea Drilling Project, Volume 21: Washington (U.S. Government Printing Office).

Coplen, T.B. and Schlanger, S.O., 1973. Oxygen and carbon isotope studies of carbonate sediments from Site 167, Magellan Rise, Leg 17. In Winterer, E.L., Ewing, J.I., et al., Initial Reports of the Deep Sea Drilling Project,
Volume 17: Washington (U.S. Government Printing Office), p. 505-509.

Crespin, I., 1963. Lower Cretaceous arenaceous foraminifera of Australia: Australia Bur. Min. Res., Geol. Geophys. Bull., v. 66, p. 1-110.

Dalziel, I.W.D., Kligfield, R., Lowrie, W., and Opdyke, N.D., 1972. Paleomagnetic data from the southernmost Andes and the Antarctandes. In Tarling, D.H. and Runcorn, S.K. (Eds.), Implications of Continental Drift to the earth sciences: New York (Academic Press), v. 1, p. 87101.

Davies, T.H., Luyendyk, B.P., et al., 1974. Initial Reports of the Deep Sea Drilling Project, Volume 26: Washington (U.S. Government Printing Office).

Douglas, R.G., 1969. Upper Cretaceous planktonic foraminifera in California. Part 1. systematic descriptions: Micropaleontology, v. 15, p. 151-209.

Douglas, R.G. and Savin, S.M., 1975. Oxygen and carbon isotope analysis of Tertiary and Cretaceous microfossils from Shatsky Rise and other sites in the north Pacific Ocean. In Larson, R.L., Moberly, R., et al., Initial Reports of the Deep Sea Drilling Project, Volume 32: Washington (U.S. Government Printing Office), p. 509-520.

Douglas, R. and Sliter, W.V., 1966. Regional distribution of some Cretaceous Rotaliporidae and Globotruncanidae (Foraminiferida) within North America: Tulane Stud. Geol., v. 4, p. 89-131.

Douglas, R.G., Moullade, M., and Nairn, A.E.M., 1973a. Causes and consequences of drift in the south Atlantic. In Tarling, D.H. and Runcorn, S.K. (Eds.), Implications of Continental Drift to the earth sciences: New York (Academic Press), v. 1, po 517-537.

Douglas, R.G., Roth, P.H., and Moore, T.C., Jr., 1973 b. Biostratigraphic synthesis: hiatuses and unconformities. In Winterer, E.L., Ewing, J.I., et al., Initial Reports of the Deep Sea Drilling Project, Volume 17: Washington (U.S. Government Printing Office), p. 905-909.

Edgell, H.S., 1954. The stratigraphical value of Bolivinoides in the Upper Cretaceous of Northwest Australia: Cushman Found. Foram. Res. Contrib., v. 5, p. 68-76. 1957. The genus Globotruncana in northwest Australia: Micropaleontology, v. 3, p. 101-126.

Franks, S. and Nairn, A.E.M., 1973. The equatorial marginal basins of west Africa. In Nairn, A.E.M. and Stehli, F.G. (Eds.), The ocean basins and margins: New York (Plenum Press), v. 1, p. 301-350.

Gartner, S., Jr., Johnson, D.A., and McGowran, B., 1974. Paleontology synthesis of Deep Sea Drilling results from Leg 22 in the northeastern Indian Ocean. In von der Borch, C.C., Sclater, J.G., et al., Initial Reports of the Deep Sea Drilling Project, Volume 22: Washington (U.S. Government Printing Office), p. 805-813.

Govindan, A., 1972. Upper Cretaceous planktonic foraminifera from the Pondicherry area, South India: Micropaleontology, v. 18, p. 160-193.

Herb, R., 1974. Cretaceous planktonic foraminifera from the Eastern Indian Ocean. In von der Borch, C.C., Sclater, J.G., et al., Initial Reports of the Deep Sea Drilling Project, Volume 22: Washington (U.S. Government Printing Office), p. 745-755.

Herm, D., 1966. Micropaleontological aspects of the Magellanese Geosyncline, southernmost Chile, South America: West African micropaleontology Colloq., 2nd, Ibadan, 1975, Proc., p. 72-86.

Hollister, C.D., et al., 1974. Deep drilling in the southeast Pacific Basin: Geotimes, p. 16-19.

Holmes, A., 1964. Principles of physical geology: New York (Ronald Press Company).

Krasheninnikov, V.A., 1974. Cretaceous and Paleogene planktonic foraminifera, Leg 27 of the Deep Sea Drilling 
Project. In Heirtzler, J., Veevers, J., et al., Initial Reports of the Deep Sea Drilling Project, Volume 27: Washington (U.S. Government Printing Office), p. 663-671.

Lambert, G., 1971. A study of the Cretaceous foraminifera of northern Zululand, South Africa: Natal Univ., Durban, South Africa, N. Sc. Thesis.

Luterbacher, H., Caron, M., Fleisher, R.L., Foreman, H.P., Toumarkine, M., and Vincent, E., 1975. In Larson, R.L., Moberly, R., et al., Initial Reports of the Deep Sea Drilling Project, Volume 32: Washington (U.S. Government Printing Office), p. 941-944.

Luyendyk, B.P., 1974. Gondwanaland dispersal and the early formation of the Indian Ocean. In Davis, T.A., Luyendyk, B., et al., Initial Reports of the Deep Sea Drilling Project, Volume 26: Washington (U.S. Government Printing Office), p. 945-952.

Luyendyk, B.P. and Davies, T.A., 1974. Results of DSDP Leg 26 and the geologic history of the southern Indian Ocean. In Davies, T.A., Luyendyk, B., et al., Initial Reports of the Deep Sea Drilling Project, Volume 26: Washington (U.S. Government Printing Office), p. 909943.

Lys, M., 1960. La limite Crétacé-Tertiare et l'Eocène inférieur dans le Bassin de Mafienga (Madagascar): Internatl. Geol. Cong. 21st, Copenhagen 1960, p. 120-130.

Malumian, N., 1969. Foramíniferos del Cretácico Superior y Terciario del subsuelo de la Provincia Santa Cruz, Argentina: Ameghiniana, v. 5, p. 191-227.

McGowran, B., 1974. Foraminifera. In von der Borch, C.C., Sclater, G., et al., Initial Reports of the Deep Sea Drilling Project, Volume 22: Washington (U.S. Government Printing Office), p. 609-627.

McKenzie, D. and Sclater, J.G., 1971. The evolution of the Indian Ocean since the Late Cretaceous: Geophys. J. R oy. Astron. Soc., v. 25, p. 437-528.

Nagoppa, Y., 1960. The Cretaceous-Tertiary boundary in the Indian-Pakistan subcontinent: Internatl. Geol. Congr. 21st Copenhagen 1960, p. 41-49.

Natland, M.L., Gonzalez, P.E., Cañon, A., and Ernst, M., 1974. A system of stages for correlation of Magallanes Basin sediments: Geol. Soc. Am. Mem. 139, p. 1-126.

Perch-Nielsen, K., et al., 1975. Leg 39 examines facies changes in South Atlantic: Geotimes, p. 26-28.

Pessagno, E.A., Jr., 1967. Upper Cretaceous planktonic foraminifera from western Gulf Coastal Plain: Palaeontologr. Am., v. 5, p. 245-445.

Pimm, A.C. and Hayes, D.E., 1972. General Synthesis. In Hayes, D.E., Pimm, A.C., et al., Initial Reports of the Deep Sea Drilling Project, Volume 14: Washington (U.S. Government Printing Office), p. 955-975.

Rona, P.A., 1973. Worldwide unconformities in marine sediments related to eustatic changes of sea level: Nature Phys. Sci., v. 244, p. 25-26.

Scheibnerová, V., 1971. Palaeoecology and palaeogeography of the Cretaceous deposits of the Great Artesian Basin (Australia): Geol. Surv. New South Wales Rec., v. 13, p. 1-48.

1972. Some interesting foraminifera from the Cretaceous of the Great Artesian Basin, Australia: Micropaleontology, v. 18, p. 212-222.

1973. Non-tropical Cretaceous foraminifera from the Atlantic deep sea cores and their implications for continental drift and palaeoceanography of the southern Atlantic Ocean: Geol. Surv. New South Wales Rec., v. 15, p. $19-46$.

1974. Aptian-Albian benthonic foraminifera from DSDP Leg 27, Sites 259, 260, and 263, Eastern Indian Ocean. In Heirtzler, J., Veevers, J., et al., Initial Reports of the Deep Sea Drilling Project, Volume 27: Washington (U.S. Government Printing Office), p. 697-741.

Sclater, J.G. and McKenzie, D.P., 1973. Paleobathymetry of the South Atlantic: Geol. Soc. Am. Bull., v. 84, p. 32033216.

Sigal, J., 1974. Comments on Leg 25 Sites in relation to the Cretaceous and Paleogene stratigraphy in the eastern and southeastern Africa coast and Madagascar regional setting. In Simpson, E.S.W., Schlich, R., et al., Initial Reports of the Deep Sea Drilling Project, Volume 25: Washington (U.S. Government Printing Office), p. $687-$ 723.

Simpson, E.S.W., Schlich, R., et al., 1974. Initial Reports of the Deep Sea Drilling Project, Volume 25: Washington (U.S. Government Printing Office).

Sliter, W.V., 1971. Predation on benthonic foraminifera: J. Foram Res., v. 1, p. 20-29.

1972. Cretaceous foraminifers-depth habitats and their origin: Nature, v. 239, p. 514-515.

1973. Upper Cretaceous foraminifers from the Vancouver Island area, British Columbia, Canada: J. Foram. Res., v. 3, p. 167-186.

1975. Foraminiferal life and residue assemblages from Cretaceous slope deposits: Geol. Soc. Am. Bull., v. 86, p. $897-906$

Sliter, W.V. and Baker, R.A., 1972. Cretaceous bathymetric distribution of benthonic foraminifers: J. Foram. Res., v. 2 , p. $167-183$.

Smith, A.G. and Hallam, A., 1970. The fit of the southern continents: Nature, v. 225, p. 139-144.

Spaeth, C., Hoefs, J., and Vetter, U., 1971. Some aspects of isotopic composition of belemnites and related paleotemperatures: Geol. Soc. Am. Bull., v. 82, p. 3139-3150.

Speden, I.G., 1974. Cretaceous Bivalvia from Cores, Leg 27. In Heirtzler, J., Veevers, J., et al., Initial Reports of the Deep Sea Drilling Project, Volume 27: Washington (U.S. Government Printing Office), p. 977-981.

Stevens, G.R., 1974. Leg 27 Cephalopoda. In Heirtzler, J., Veevers, J., et al., Initial Reports of the Deep Sea Drilling Project, Volume 27: Washington (U.S. Government Printing Office), p. 983-989.

Stevens, G.R. and Clayton, R.N., 1971. Oxygen isotope studies on Jurassic and Cretaceous belemnites from New Zealand and their biogeographic significance: New Zealand J. Geol. Geophys., V. 14, p. 829-897.

Thierstein, H.R., 1974. Calcareous nannoplankton-Leg 26, Deep Sea Drilling Project. In Davis, T.A., Luyendyk, K.B., et al., Initial Reports of the Deep Sea Drilling Project, Volume 26: Washington (U.S. Government Printing Office), p. 619-667.

Todd, R., 1968. Maestrichtian (Late Cretaceous) Foraminifera from a deep-sea core off southwestern Africa: Rev. Española Micropaleontol., v. 2, p. 131-154.

Veevers, J.J., Heirtzler, J.R., et al., 1974. Initial Reports of the Deep Sea Drilling Project, Volume 27: Washington (U.S. Government Printing Office).

Veevers, J.J. and Johnston, M.H., 1974. Comparative stratigraphy and structure of the western Australian margin and the adjacent deep ocean floor. In Heirtzler, J., Veevers, J., et al., Initial Reports of the Deep Sea Drilling Project, Volume 27: Washington (U.S. Government Printing Office), p. 571-585.

Visser, W.A. and Hermes, J.J., 1962. Geological results of the exploration for oil in Netherlands New Guinea: Verh. Geol.-Mijnb. Genoost. Ned. Kolon., v. 20, p. 1-265.

von der Borch, C.C., Sclater, J.G., et al., 1974. Initial Reports of the Deep Sea Drilling Project, Volume 22: Washington (U.S. Government Printing Office). 
Webb, P.N., 1971. New Zealand Late Cretaceous (Haumurian) foraminifera and stratigraphy: A summary: New Zealand J. Geol. Geophys., v. 14, p. 795-828.
Wright, C.A., and Apthorpe, M., in press. Planktonic foraminiferids from the Maestrichtian of the northwest shelf, Western Australia: J. Foram. Res. 


\section{PLATE 1}

Figures 1-4 Hedbergella amabilis Loeblich and Tappan. Sample $327 \mathrm{~A}-18-6,26-28 \mathrm{~cm}$.

1. Spiral view, dot width $30 \mu \mathrm{m}$.

2. Peripheral view, dot width $30 \mu \mathrm{m}$.

3. Umbilical view, dot width $100 \mu \mathrm{m}$.

4. Umbilical view showing elongate final chamber. Dot width $100 \mu \mathrm{m}$.

Figures 5-9 Hedbergella delrioensis (Carsey). Sample 327A-152, $15-17 \mathrm{~cm}$.

5. Spiral view, dot width $30 \mu \mathrm{m}$.

6. Peripheral view, dot width $100 \mu \mathrm{m}$.

7. Umbilical view, dot width $30 \mu \mathrm{m}$.

8. Spiral view, dot width $100 \mu \mathrm{m}$.

9. Peripheral view of specimen with less inflated final chambers. Dot width $30 \mu \mathrm{m}$. 
PLATE 1

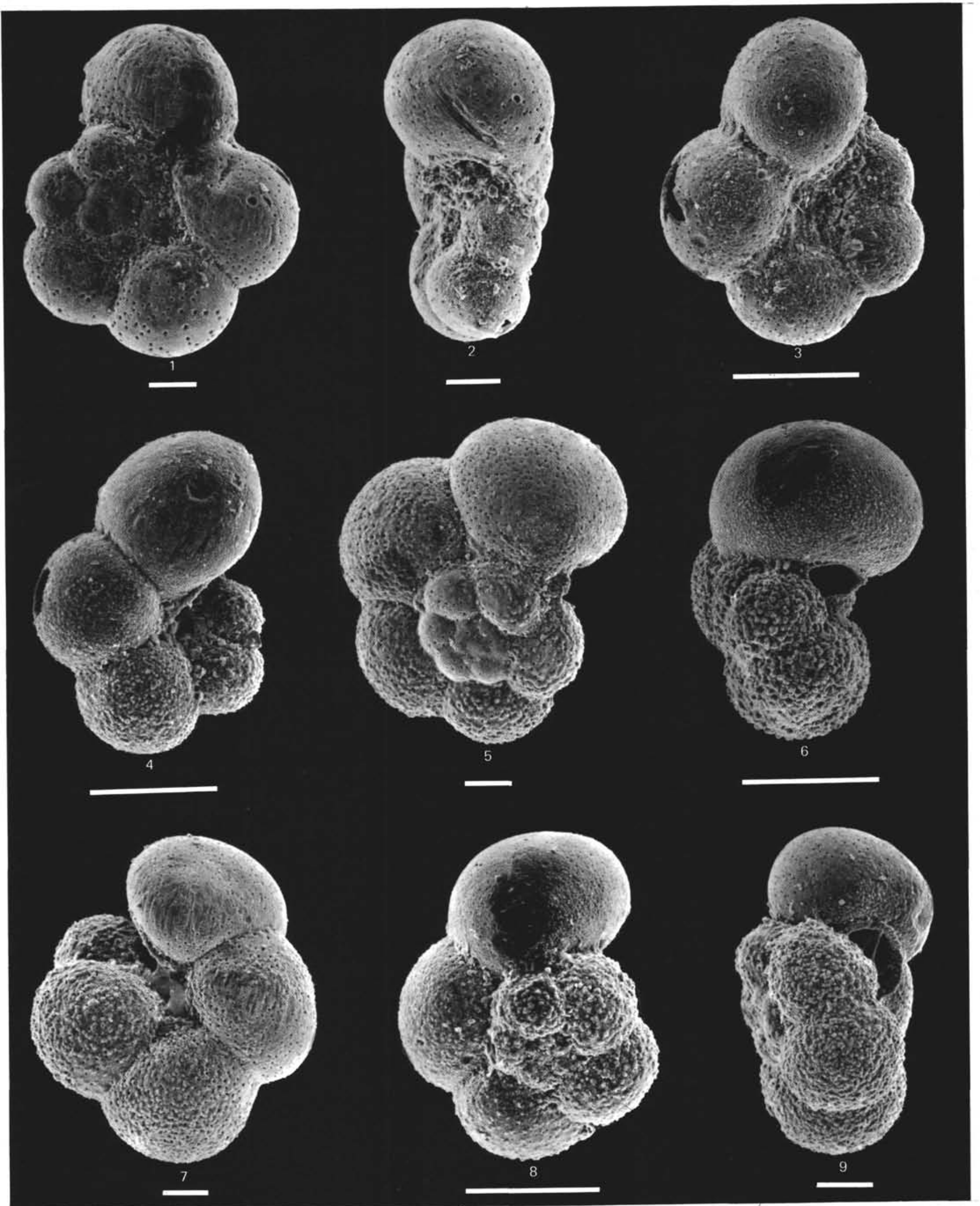




\section{PLATE 2}

Figures 1-4 Hedbergella holmdelensis Olsson. Sample 327A$12-1,69-72 \mathrm{~cm}$.

1. Spiral view, dot width $100 \mu \mathrm{m}$.

2. Peripheral view, dot width $30 \mu \mathrm{m}$.

3. Umbilical view, dot width $30 \mu \mathrm{m}$.

4. Spiral view of specimen with more ovate chambers. Dot width $30 \mu \mathrm{m}$.

Figures 5-8 Hedbergella infracretacea (Glaessner). Sample 327 A-16-2, $129-131 \mathrm{~cm}$.

5. Spiral view, dot width $30 \mu \mathrm{m}$.

6. Peripheral view, dot width $30 \mu \mathrm{m}$.

7. Spiral view, dot width $30 \mu \mathrm{m}$.

8. Umbilical view, dot width $30 \mu \mathrm{m}$. 
PLATE 2
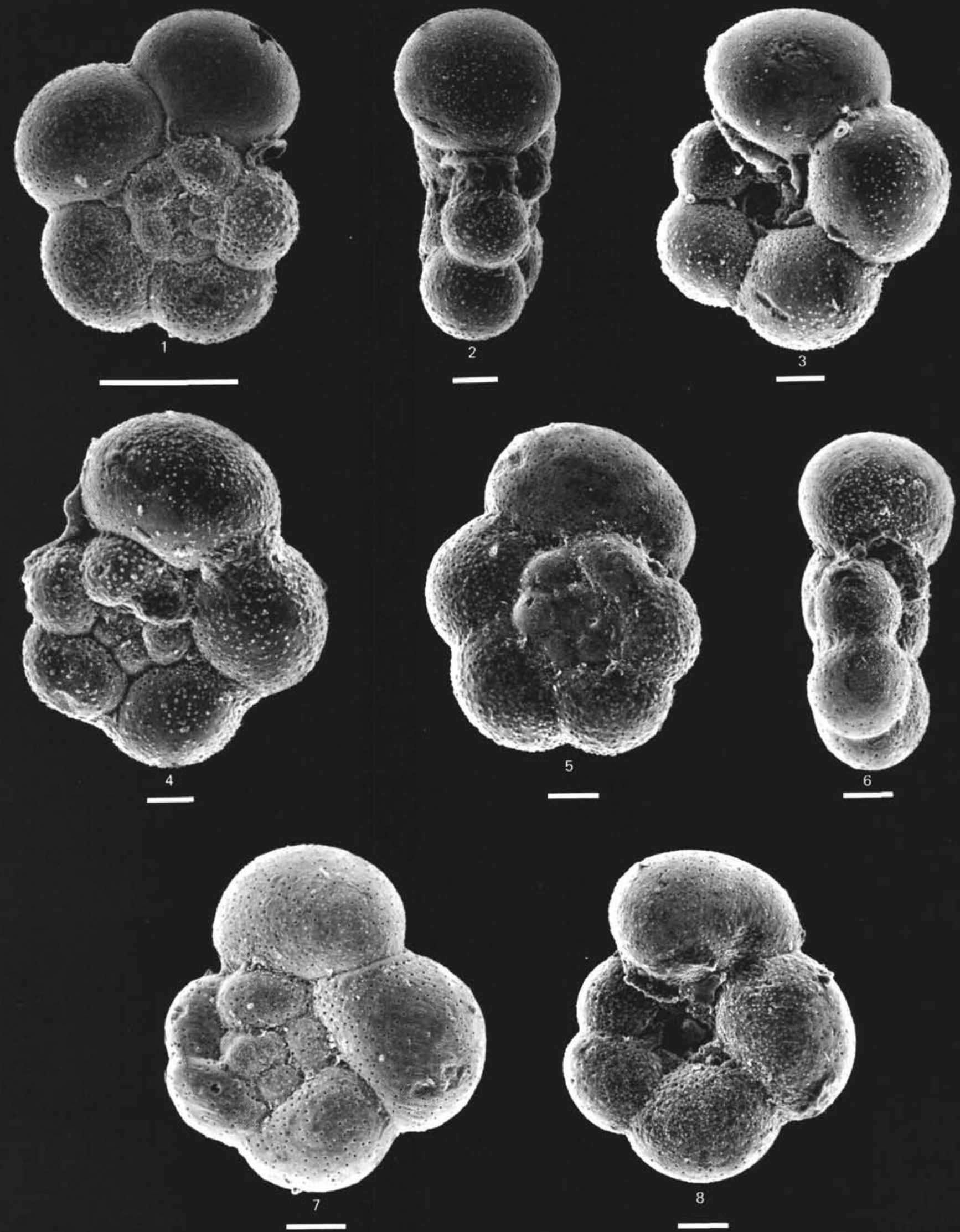


\section{PLATE 3}

Figures 1-3 Hedbergella monmouthensis (Olsson). Sample 327A-12-1, 69-72 cm.

1. Spiral view, dot width $30 \mu \mathrm{m}$.

2. Peripheral view, dot width $30 \mu \mathrm{m}$.

3. Umbilical view, dot width $30 \mu \mathrm{m}$.

Figures 4-7 Hedbergella planispira (Tappan). Sample 327A-18-

$6,26-28 \mathrm{~cm}$.

4. Spiral view, dot width $30 \mu \mathrm{m}$.

5. Peripheral view, dot width $30 \mu \mathrm{m}$.

6. Umbilical view, dot width $30 \mu \mathrm{m}$.

7. Spiral view, dot width $30 \mu \mathrm{m}$.

Figures 8,9 Globigerinelloides gyroidinaeformis Moullade. Sample 327A-21-2, $36-38 \mathrm{~cm}$.

8. Side view, dot width $30 \mu \mathrm{m}$.

9. Peripheral view, dot width $30 \mu \mathrm{m}$. 
PLATE 3

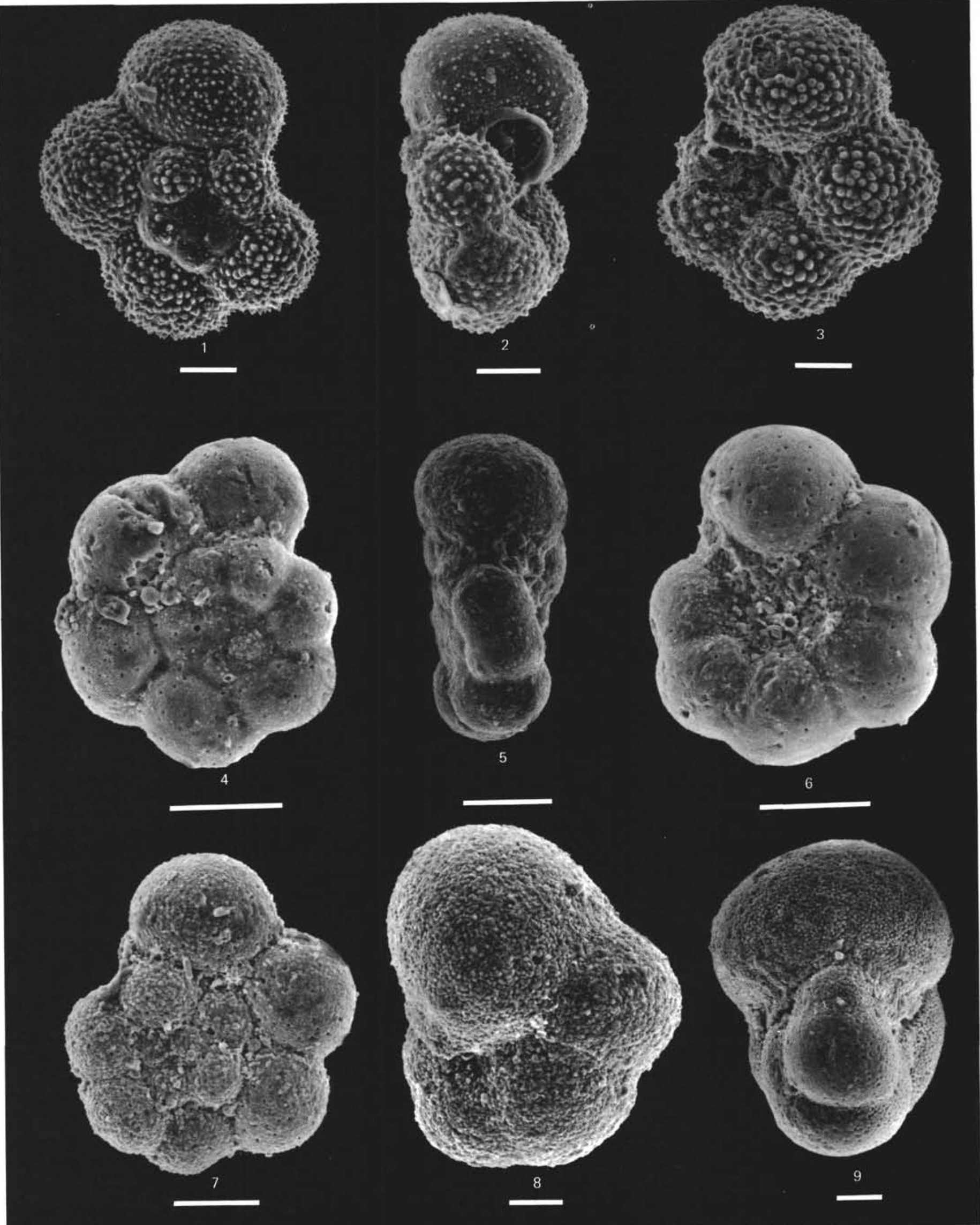




\section{PLATE 4}

Figures 1-5 Hedbergella portsdownensis (Williams-Mitchell). Sample 327A-16-2, 129-131 cm.

1. Spiral view, dot width $30 \mu \mathrm{m}$.

2. Peripheral view, dot width $30 \mu \mathrm{m}$.

3. Umbilical view, dot width $30 \mu \mathrm{m}$.

4. Spiral view showing accessory aperture in ultimate chambers. Dot width $30 \mu \mathrm{m}$.

5. Spiral view of another specimen with accessory aperture. Dot width $30 \mu \mathrm{m}$.

Figures 6-8 Hedbergella sigali Moullade. Sample 327A-21-4, 105-107 cm.

6. Spiral view, dot width $30 \mu \mathrm{m}$.

7. Peripheral view, dot width $30 \mu \mathrm{m}$.

8. Umbilical view, dot width $30 \mu \mathrm{m}$. 
PLATE 4

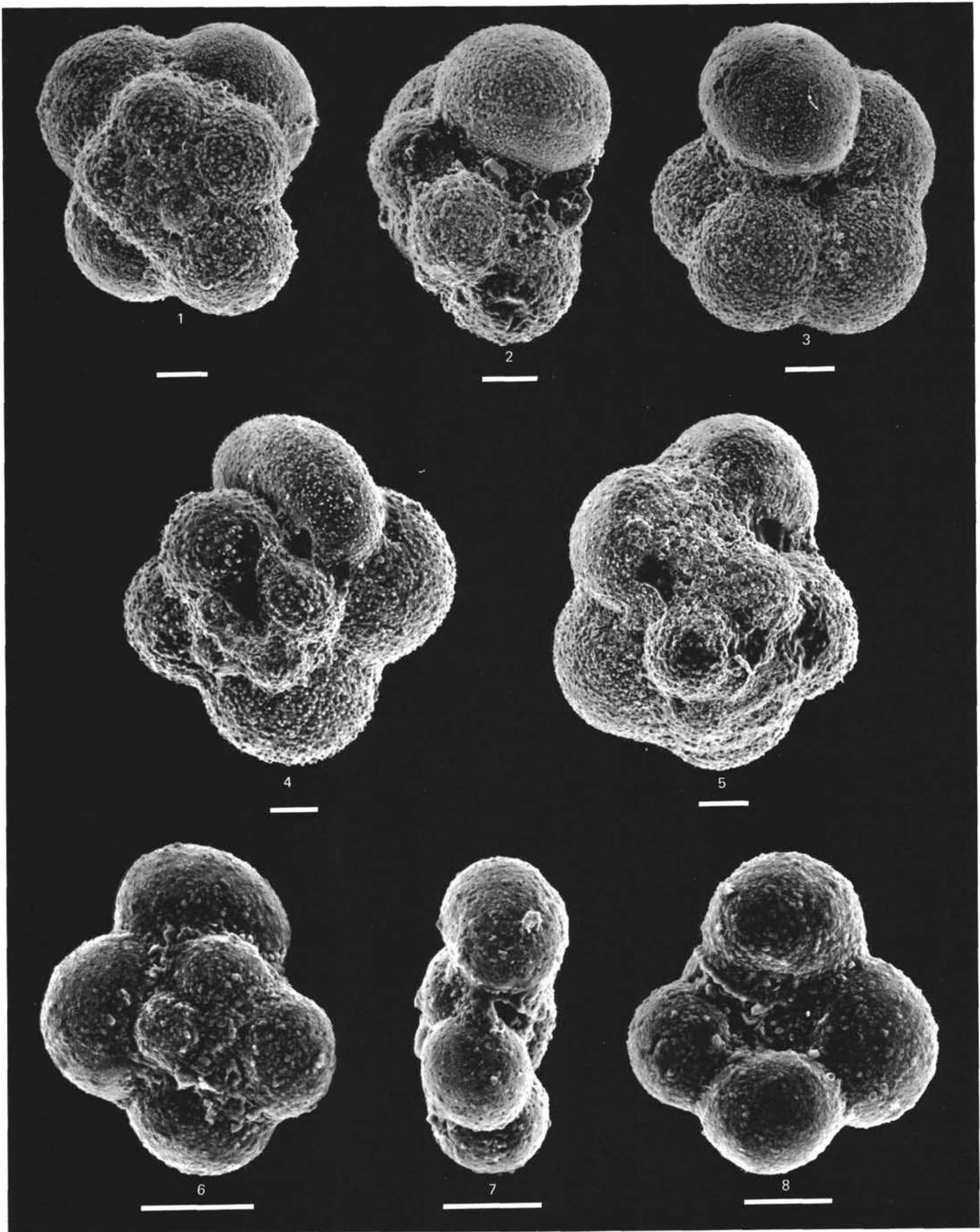




\section{PLATE 5}

Figures 1,2 Hedbergella sigali Moullade. Sample 327A-21-2, $36-38 \mathrm{~cm}$.

1. Spiral view, dot width $30 \mu \mathrm{m}$.

2. Umbilical view, dot width $30 \mu \mathrm{m}$.

Figures 3, 6 Globigerinelloides caseyi (Bolli, Loeblich, and Tappan). Sample 327A-19-2, 61-63 cm.

3. Side view, dot width $30 \mu \mathrm{m}$.

6. Peripheral view, dot width $100 \mu \mathrm{m}$.

Figures 4, 5 Globigerinelloides bentonensis (Morrow). Sample $327 \mathrm{~A}-17-2,50-52 \mathrm{~cm}$.

4. Side view of broken specimen. Dot width 100 $\mu \mathrm{m}$.

5. Peripheral view, dot width $100 \mu \mathrm{m}$.

Figures 7-9 Globigerinelloides multispinatus (Lalicker). Sample 327A-12-2, 94-96 cm.

7. Side view, dot width $30 \mu \mathrm{m}$.

8. Peripheral view, dot width $100 \mu \mathrm{m}$.

9. Peripheral view of specimen with double aperture. Dot width $30 \mu \mathrm{m}$. 
PLATE 5

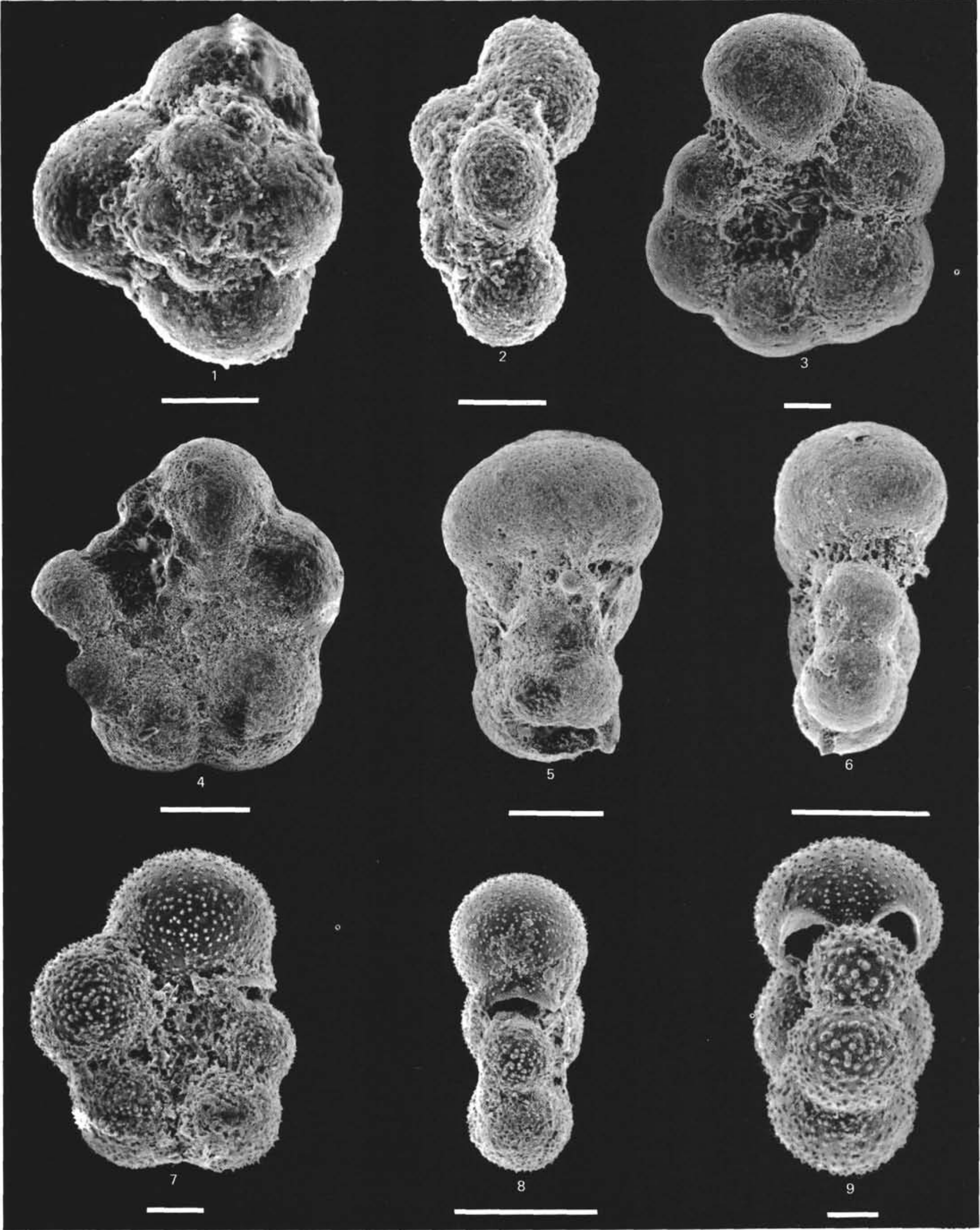




\section{PLATE 6}

Figures 1-3 Globigerinelloides impensus Sliter, n. sp. Sample $327 \mathrm{~A}-13$, CC.

1. Side view of holotype. Dot width $100 \mu \mathrm{m}$.

2. Peripheral view of paratype. Dot width $100 \mu \mathrm{m}$.

3. Side view of paratype. Dot width $100 \mu \mathrm{m}$.

Figures 4-6 Heterohelix globulosa (Ehrenberg). Sample 327A$11-1,11-13 \mathrm{~cm}$.

4. Side view, dot width $30 \mu \mathrm{m}$.

5. Side view, dot width $30 \mu \mathrm{m}$.

6. Side view, dot width $100 \mu \mathrm{m}$.

Figures 7-9 Heterohelix pulchra (Brotzen). Sample 327A-11-1, $11-13 \mathrm{~cm}$.

7. Side view, dot width $100 \mu \mathrm{m}$.

8. Side view, dot width $100 \mu \mathrm{m}$.

9. Side view, dot width $100 \mu \mathrm{m}$. 
PLATE 6

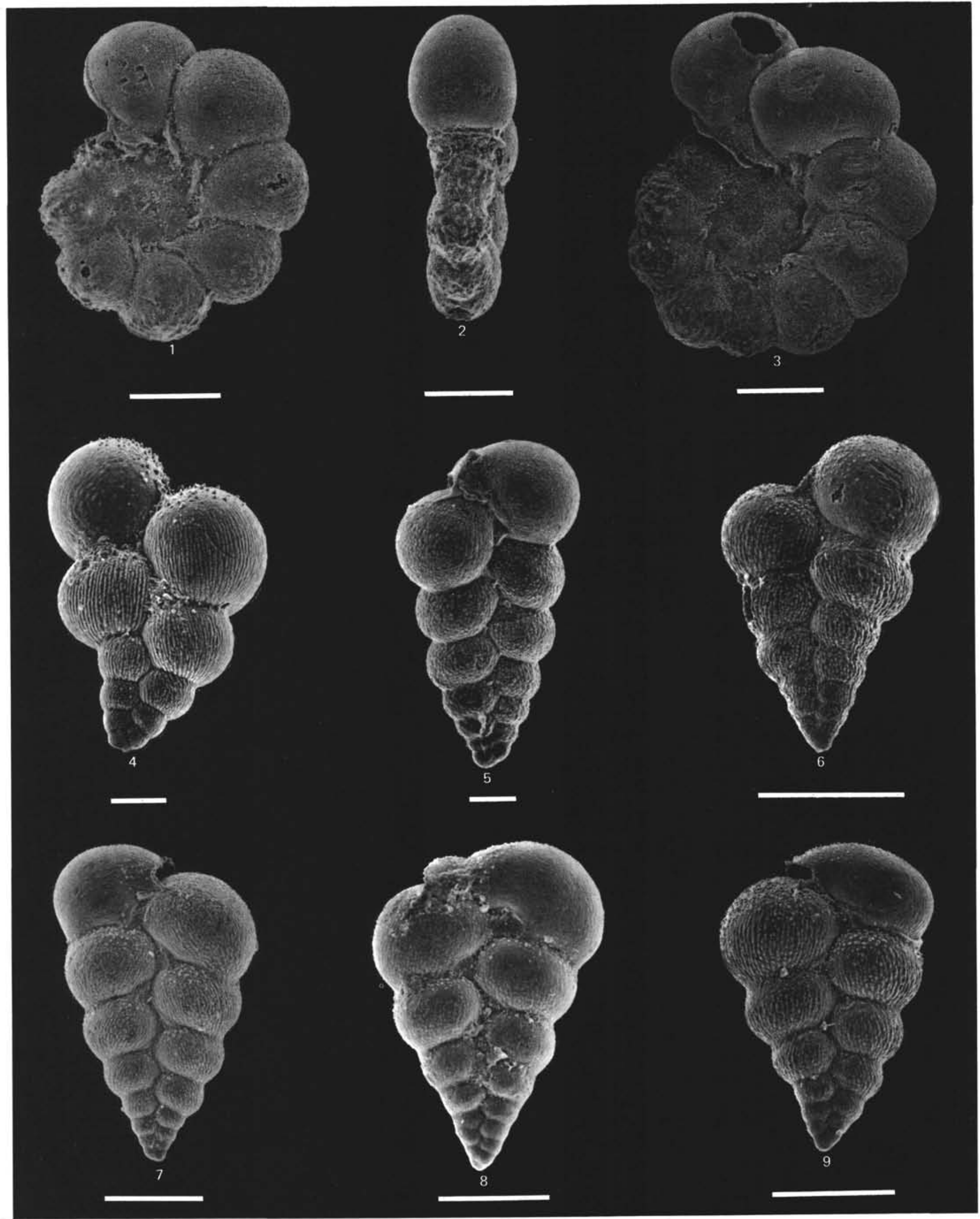




\section{PLATE 7}

Figure 1 Heterohelix glabrans (Cushman). Sample 327A$12-1,69-72 \mathrm{~cm}$. Side view, dot width $30 \mu \mathrm{m}$.

Figures 2, 3 Heterohelix reussi (Cushman). Sample 327A-14-2, $143-145 \mathrm{~cm}$.

2. Side view, dot width $30 \mu \mathrm{m}$.

3. Side view, dot width $30 \mu \mathrm{m}$.

Figures 4-6 Planoglobulina carseyae (Plummer). Sample 327A13, CC.

4. Side view of specimen with irregular ultimate chambers. Dot wdith $100 \mu \mathrm{m}$.

5. Side view, dot width $100 \mu$.

6. Side view, dot width $100 \mu \mathrm{m}$.

Figure 7 Schackoina cenomana (Schacko). Sample 327A-14, CC. Side view, dot width $30 \mu \mathrm{m}$.

Figures 8,9 Schackoina multispinata (Cushman and Wickenden). Sample 327A-13, CC.

8. Side view, dot width $100 \mu \mathrm{m}$.

9. Side view, dot width $100 \mu \mathrm{m}$. 
PLATE 7

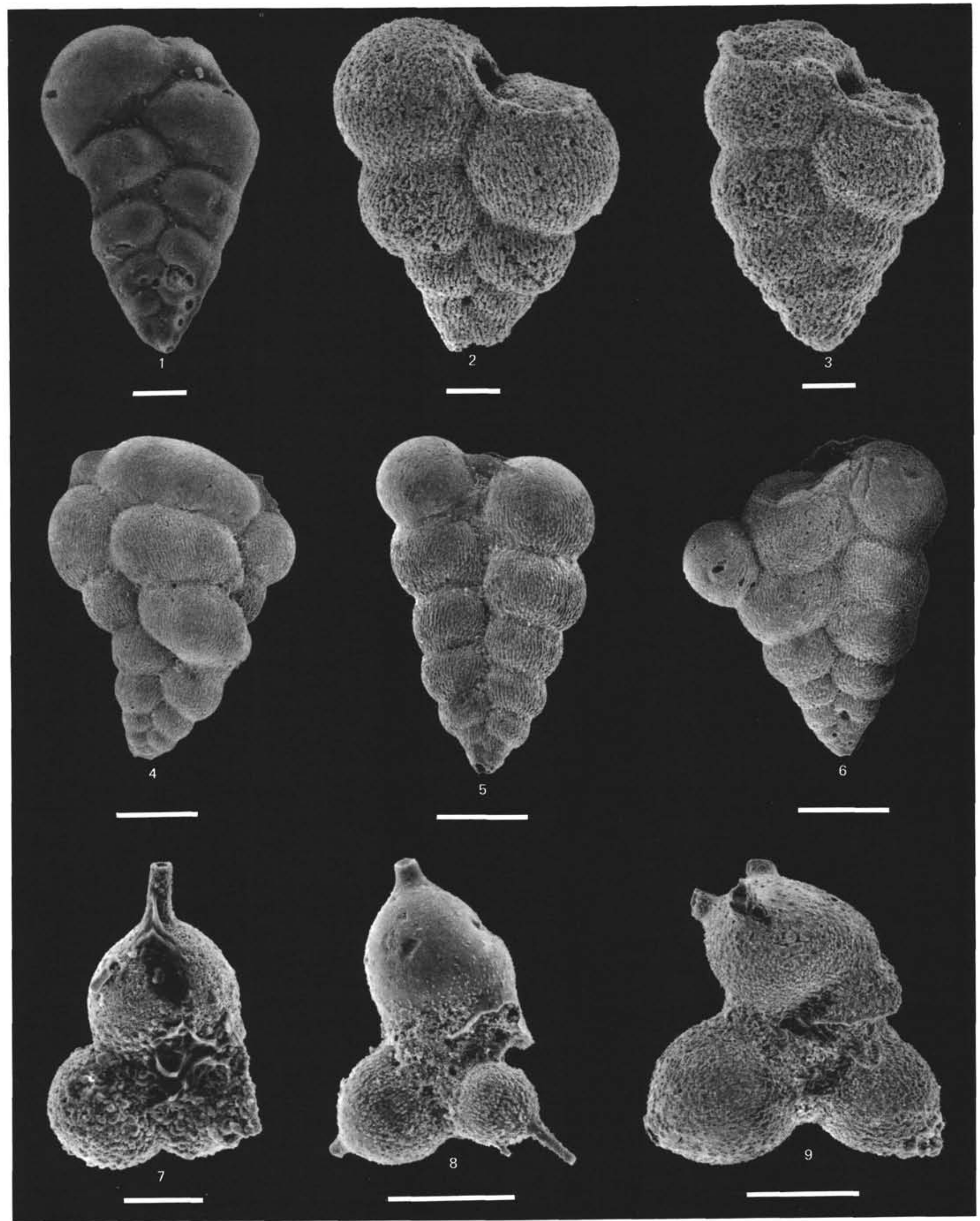




\section{PLATE 8}

Figures 1-3, 6 Praeglobotruncana delrioensis (Plummer). Sample $327 \mathrm{~A}-15-1,45-47 \mathrm{~cm}$.

1. Spiral view, dot width $100 \mu \mathrm{m}$.

2. Peripheral view, dot width $100 \mu \mathrm{m}$.

3. Umbilical view, dot width $100 \mu \mathrm{m}$.

6. Umbilical view, dot width $100 \mu \mathrm{m}$.

Figures 4, 5, 7 Rotalipora reicheli (Mornod). Sample 327A-14-6, $69-71 \mathrm{~cm}$.

4. Spiral view, dot width $100 \mu \mathrm{m}$.

5. Umbilical view of fragment, dot width $100 \mu \mathrm{m}$.

7. Umbilical view of fragment, dot width $100 \mu \mathrm{m}$.

Figures 8,9 Whiteinella baltica Douglas and Rankin. Sample 327A-14-1, 120-122 cm.

8. Spiral view, dot width $30 \mu \mathrm{m}$.

9. Oblique view, showing kummerform final chamber. Dot width $30 \mu \mathrm{m}$. 
PLATE 8

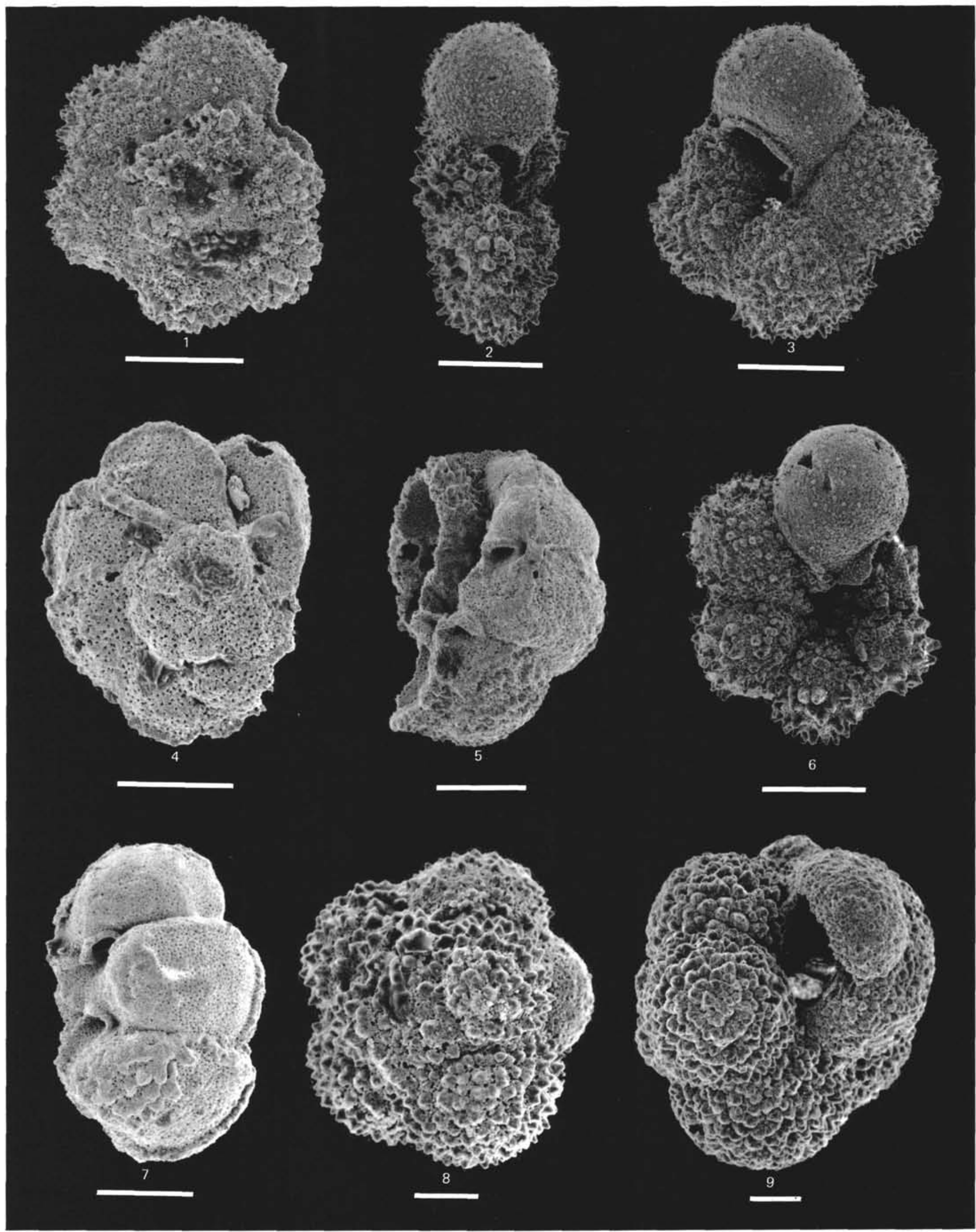




\section{PLATE 9}

Figures 1, 2 Whiteinella baltica Douglas and Rankin. Sample 327A-14-1, 120-122 cm.

1. Umbilical view of specimen with kummerform final chamber. Dot width $30 \mu \mathrm{m}$.

2. Peripheral view, dot width $30 \mu \mathrm{m}$.

Figures 3-5 Archaeglobigerina bosquensis Pessagno. Sample 327A-14-1, 120-122 cm.

3. Spiral view, dot width $30 \mu \mathrm{m}$.

4. Peripheral view, dot width $100 \mu \mathrm{m}$.

5. Umbilical view, dot width $100 \mu \mathrm{m}$.

Figures 6, 7 Globotruncana arca (Cushman). Sample 327A-10-

$2,139-141 \mathrm{~cm}$.

6. Umbilical view, dot width $100 \mu \mathrm{m}$.

7. Peripheral view, dot width $100 \mu \mathrm{m}$. 


\section{PLATE 9}
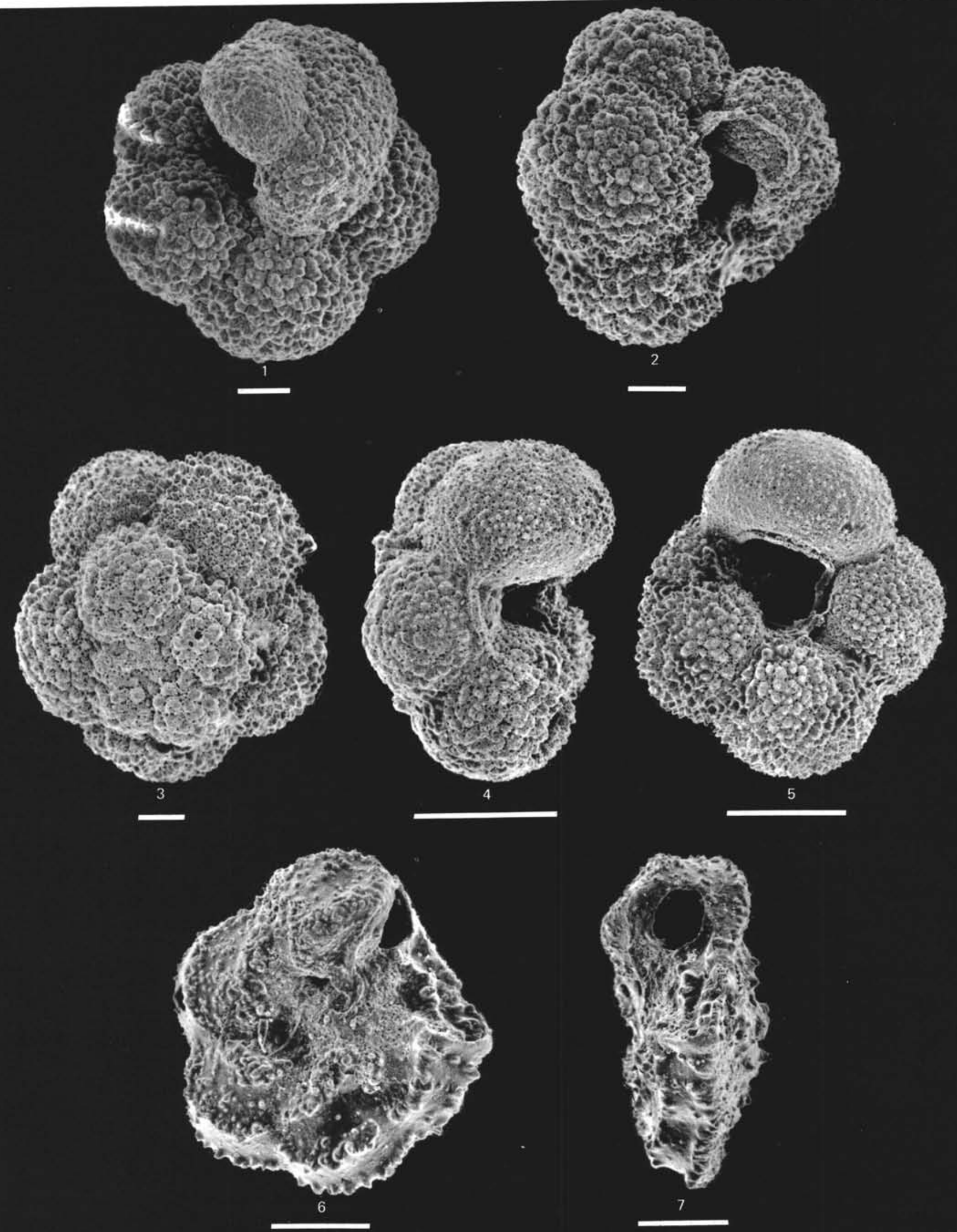


\section{PLATE 10}

Figures 1-6 Globotruncanella havanensis (Voorwijk). Sample 327A-11-1, 11-13 cm.

1. Spiral view, dot width $100 \mu \mathrm{m}$.

2. Peripheral view, dot width $100 \mu \mathrm{m}$.

3. Umbilical view, dot width $100 \mu \mathrm{m}$.

4. Umbilical view, dot width $100 \mu \mathrm{m}$.

5. Peripheral view, dot width $100 \mu \mathrm{m}$.

6. Umbilical view, dot width $100 \mu \mathrm{m}$.

Figures 7-9 Rugoglobigerina pilula Belford. Sample 327A-13-2, $61-63 \mathrm{~cm}$.

7. Spiral view, dot width $100 \mu \mathrm{m}$.

8. Peripheral view, dot width $100 \mu \mathrm{m}$.

9. Umbilical view, dot width $100 \mu \mathrm{m}$. 

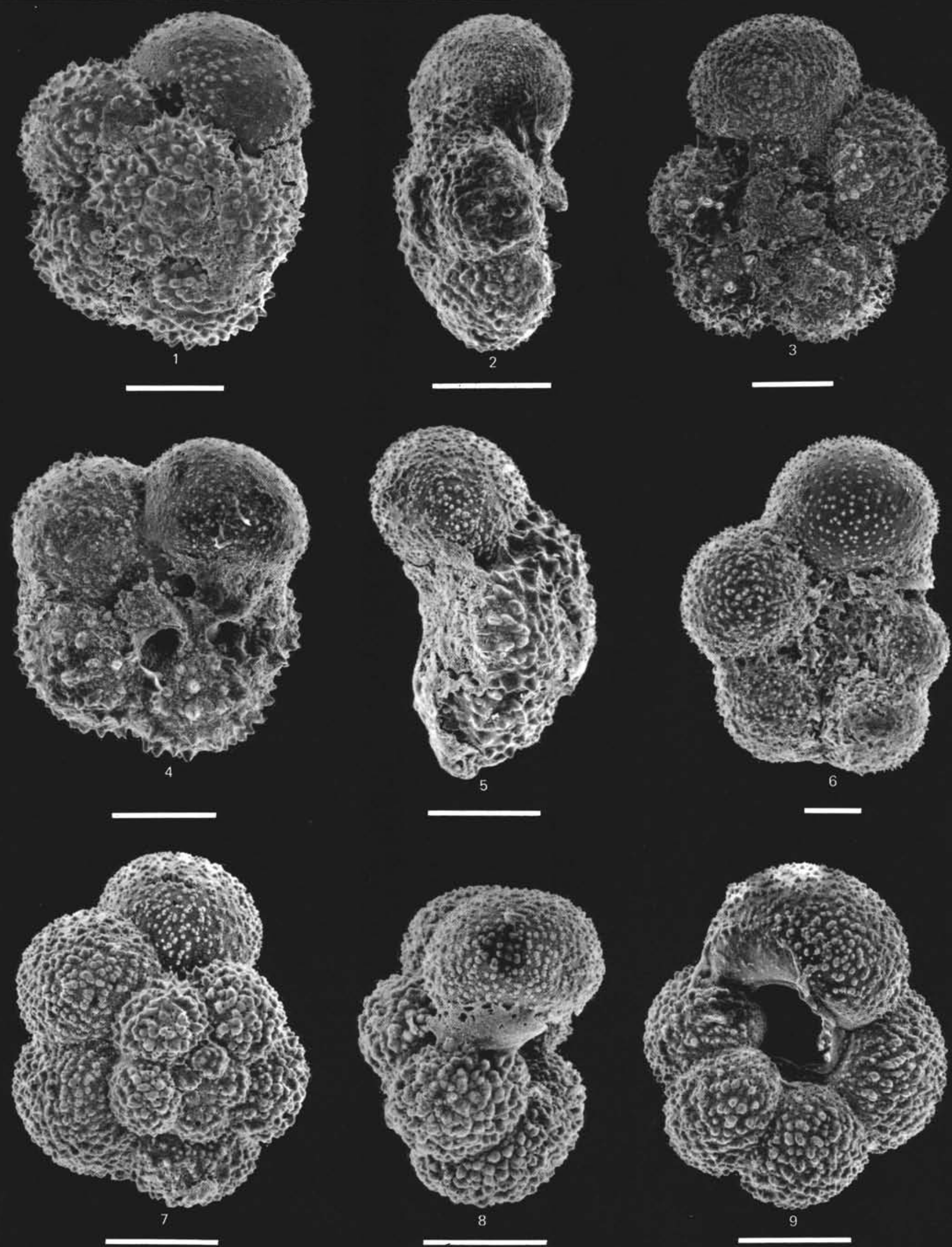


\section{PLATE 11}

Figures 1-3 Rugoglobigerina rotundata Brönnimann. Sample 327A-12-1, 69-72 cm.

1. Spiral view, dot width $100 \mu \mathrm{m}$.

2. Peripheral view, dot width $100 \mu \mathrm{m}$.

3. Umbilical view, dot width $100 \mu \mathrm{m}$.

Figures 4-6 Rugoglobigerina pustulata Brönnimann. Sample 327A-12-1, 69-72 cm.

4. Spiral view, dot width $100 \mu \mathrm{m}$.

5. Peripheral view, dot width $100 \mu \mathrm{m}$.

6. Umbilical view, dot width $100 \mu \mathrm{m}$.

Figure 7 Uvigerinammina janckoi Majzon. Sample 327A-16$1,117-119 \mathrm{~cm}$. Dot width $100 \mu \mathrm{m}$.

Figure 8 Dorothia trochus (d'Orbigny). Sample 327A-29-2, $31-33 \mathrm{~cm}$. Dot width $100 \mu \mathrm{m}$.

Figure 9 Tritaxia gabonica (LeCalvez, de Klasz, and Brun). Sample 327A-21-2, 36-38 cm. Dot width $300 \mu \mathrm{m}$. 
PLATE 11

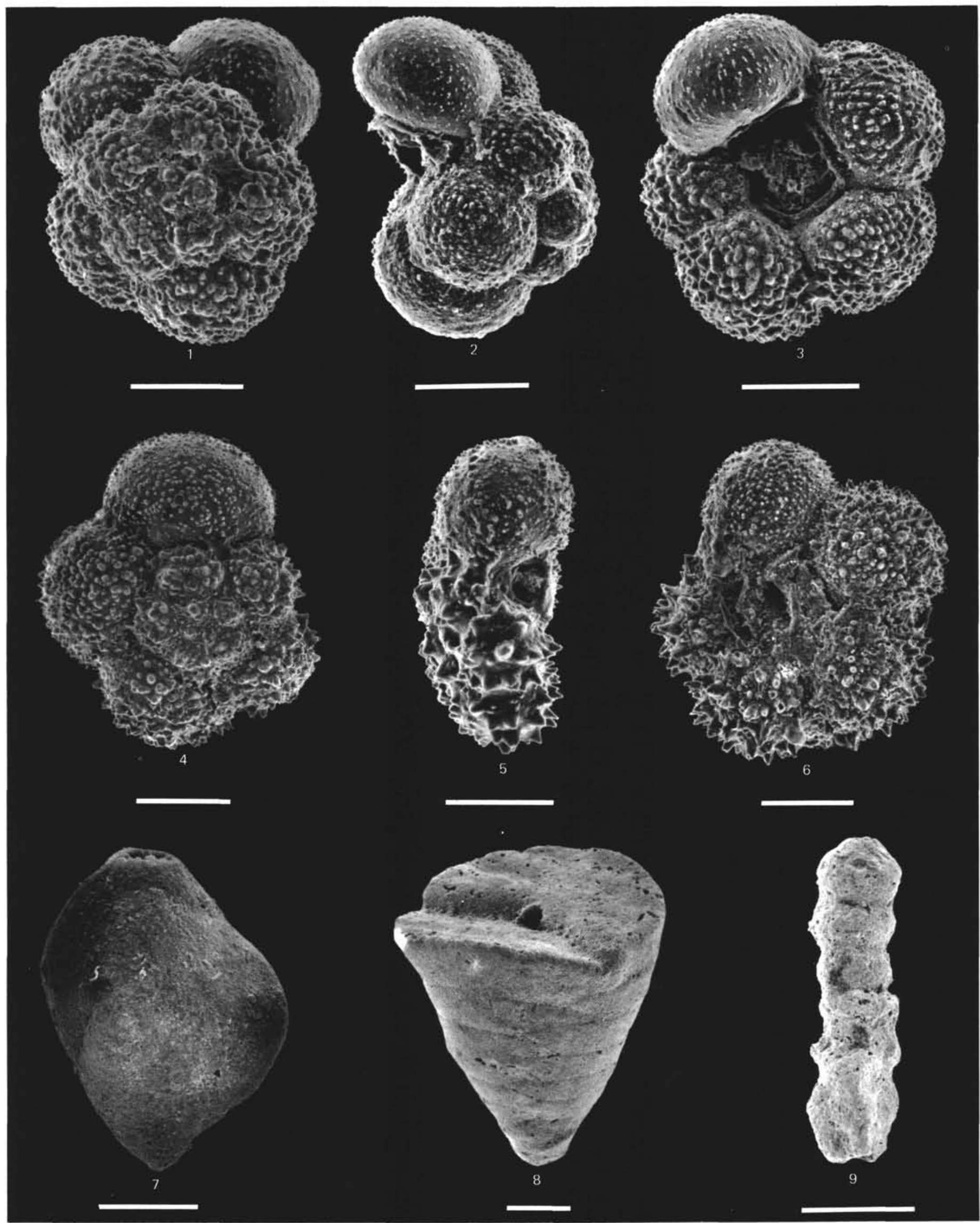




\section{PLATE 12}

Figure 1 Dentalinopsis quadrata Reuss. Sample 327A-17-2, $50-52 \mathrm{~cm}$. Dot width $100 \mu \mathrm{m}$.

Figure 2 Neoflabellina praereticulata Hiltermann. Sample $327 \mathrm{~A}-13$, CC. Dot width $100 \mu \mathrm{m}$.

Figures 3, 4 Tribrachia australiana Ludbrook. Sample 327A21-2, 36-38 cm. Dot widths $100 \mu \mathrm{m}$.

Figures 5,6 Spirobolivina australis Scheibnerová. Sample 327A-20-2, 36-38 cm. Dot widths $100 \mu \mathrm{m}$.

Figure 7 Bolivina incrassata Reuss. Sample 327A-10, CC. Dot width $100 \mu \mathrm{m}$.

Figure 8 Bolivinoides laevigatus Marie. Sample 327A-13-2, 61-63 cm. Dot width $30 \mu \mathrm{m}$.

Figure 9 Reussella szajnochae (Grzybowski). Sample 327A13, CC. Dot width $100 \mu \mathrm{m}$.

Figure $10 \quad$ Patellinella australis Lambert and Scheibnerová. Sample 327A-16-1, 117-119 cm. Dot width $30 \mu \mathrm{m}$. 
PLATE 12

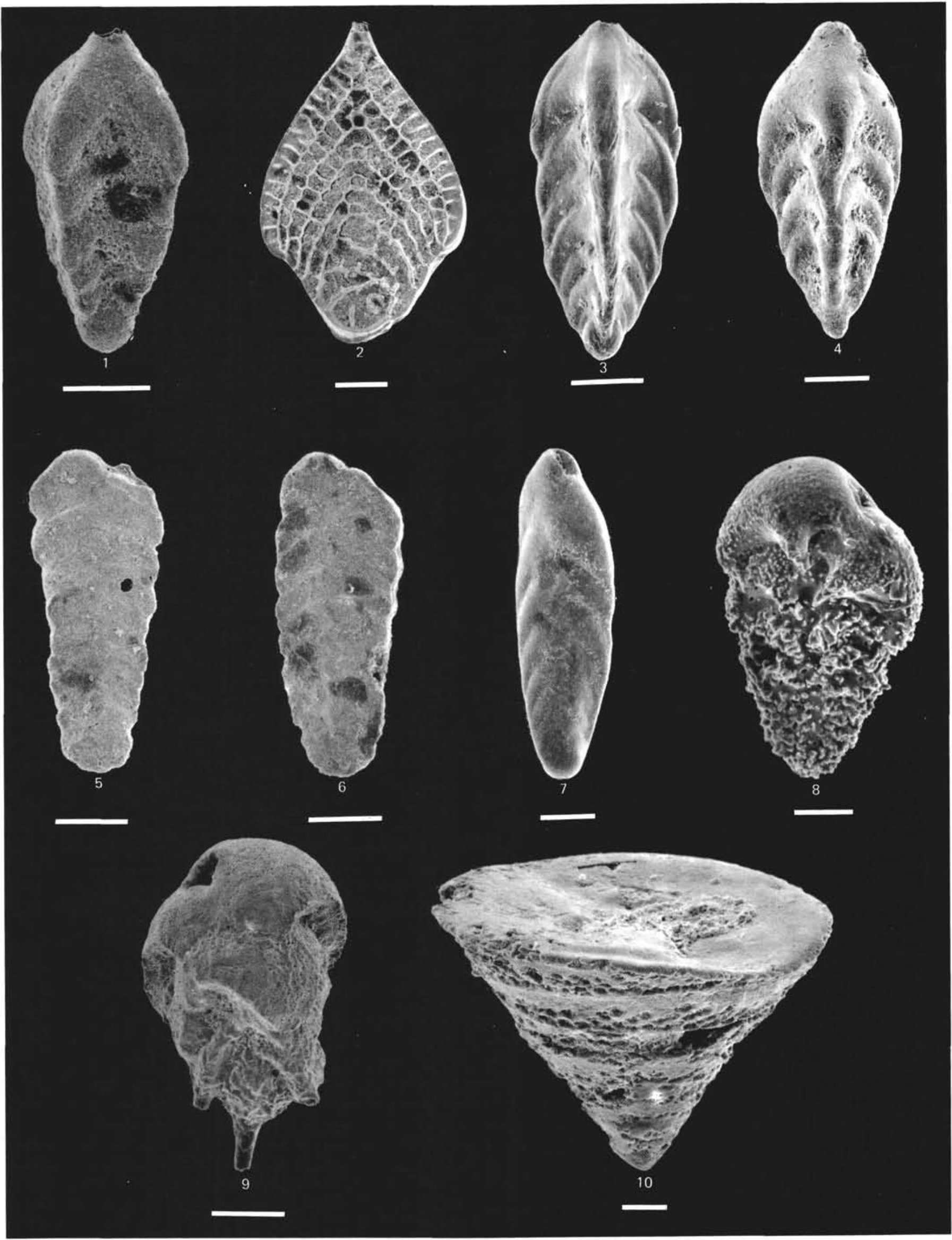




\section{PLATE 13}

Figures 1,2 Aragonia materna kugleri Beckmann and Koch. Sample 327A-14-1, 120-122 cm.

1. Dot width $100 \mu \mathrm{m}$.

2. Dot width $30 \mu \mathrm{m}$.

Figure 3 Globorotalites spineus (Cushman). Sample 327A13-2, 61-63 cm. Dot width $100 \mu \mathrm{m}$.

Figures 4, 5 Osangularia utaturensis (Sastry and Sastri). Sample $327 \mathrm{~A}-21-2,36-38 \mathrm{~cm}$. Dot widths $100 \mu \mathrm{m}$.

Figure 6 Gavelinella intermedia (Berthelin). Sample 327A20-2, 31-33 cm. Dot width $100 \mu \mathrm{m}$.

Figures 7, $8 \quad$ Conorboides minutissima (Tappan). Sample 327A$16-1,117-119 \mathrm{~cm}$. Dot widths $100 \mu \mathrm{m}$. 
PLATE 13

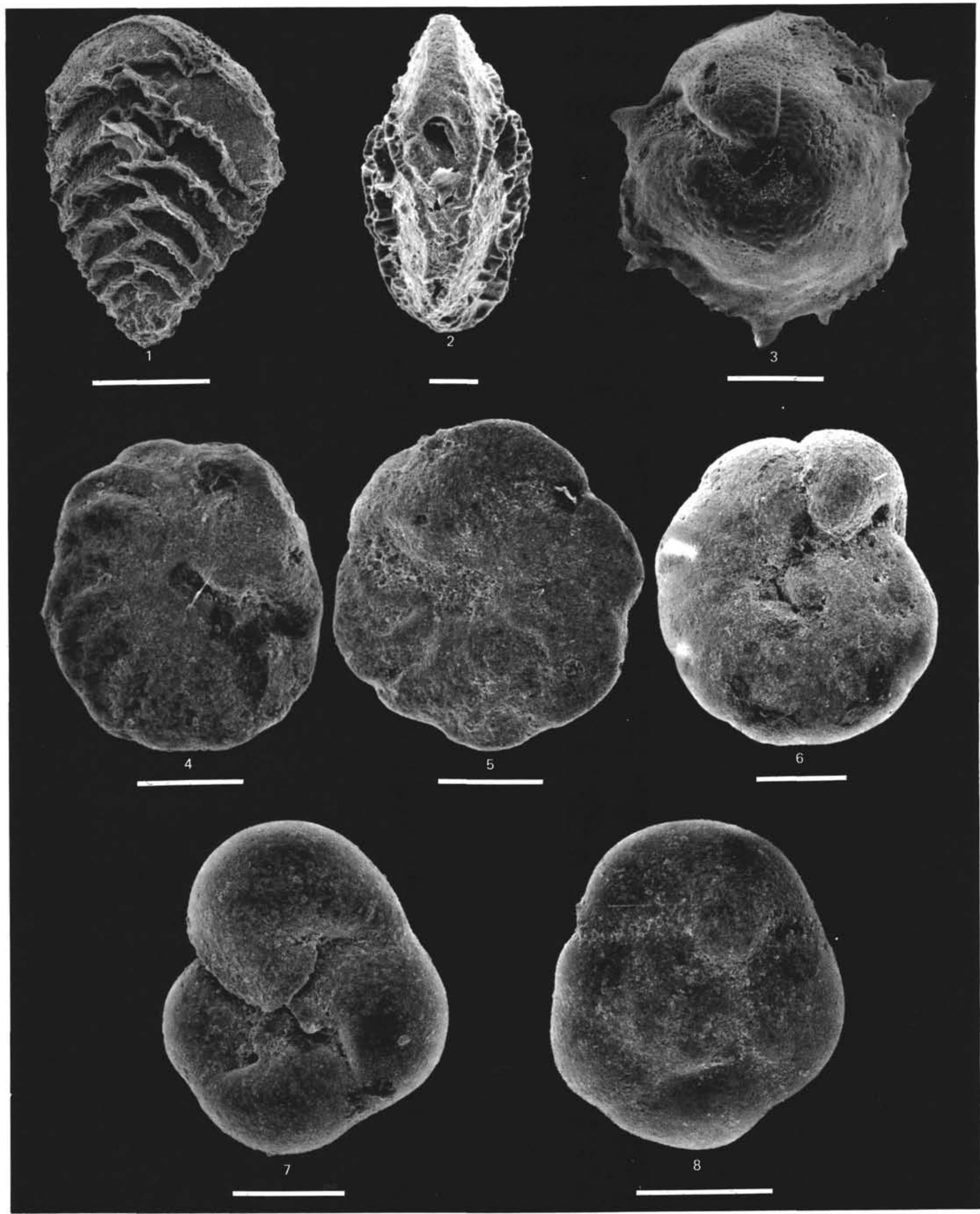




\section{PLATE 14}

Figures 1-8 Calcareous organism incertae sedis. Sample 327A$14-1,120-122 \mathrm{~cm}$.

1. Apical view showing polygonal shape and perforations. Dot width $30 \mu \mathrm{m}$.

2. Side view, dot width $10 \mu \mathrm{m}$.

3. Inside view of recrystallized, broken specimen. Dot width $10 \mu \mathrm{m}$.

4. Detail of apical area of Figure 1 showing the corroded subhedral calcite crystals that form the wall. Dot with $30 \mu \mathrm{m}$.

5. Detail of interior of Figure 3. Overgrowth of crystals lining basal pore is clearly shown. Dot width $10 \mu \mathrm{m}$.

6-8. Overgrowth series.

6. Side view of specimen with slight overgrowth, dot width $30 \mu \mathrm{m}$.

7. Side view of specimen with moderate overgrowth, dot width $30 \mu \mathrm{m}$.

8. Side view of specimen with severe overgrowth, dot width $10 \mu \mathrm{m}$. 
PLATE 14
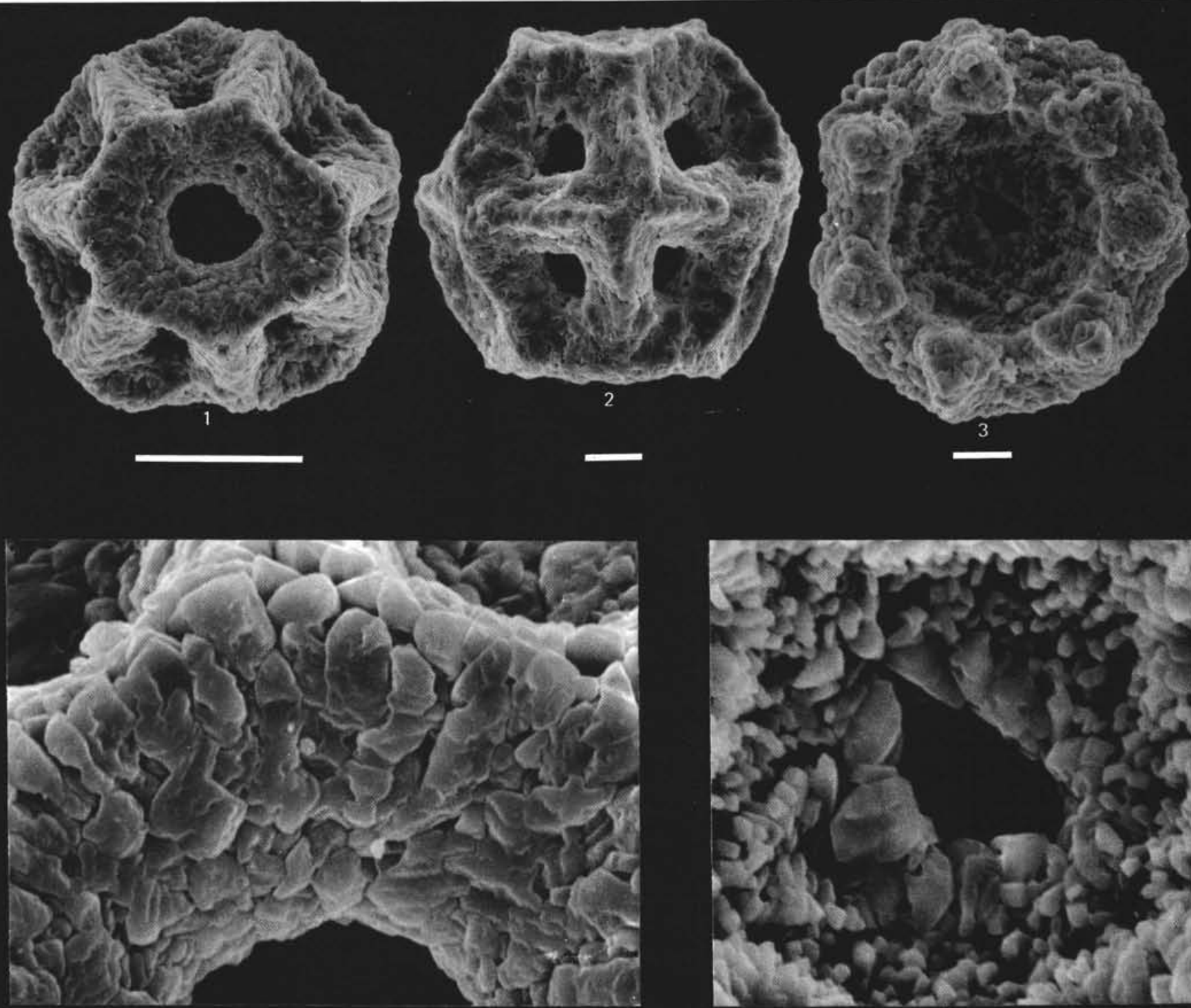

4
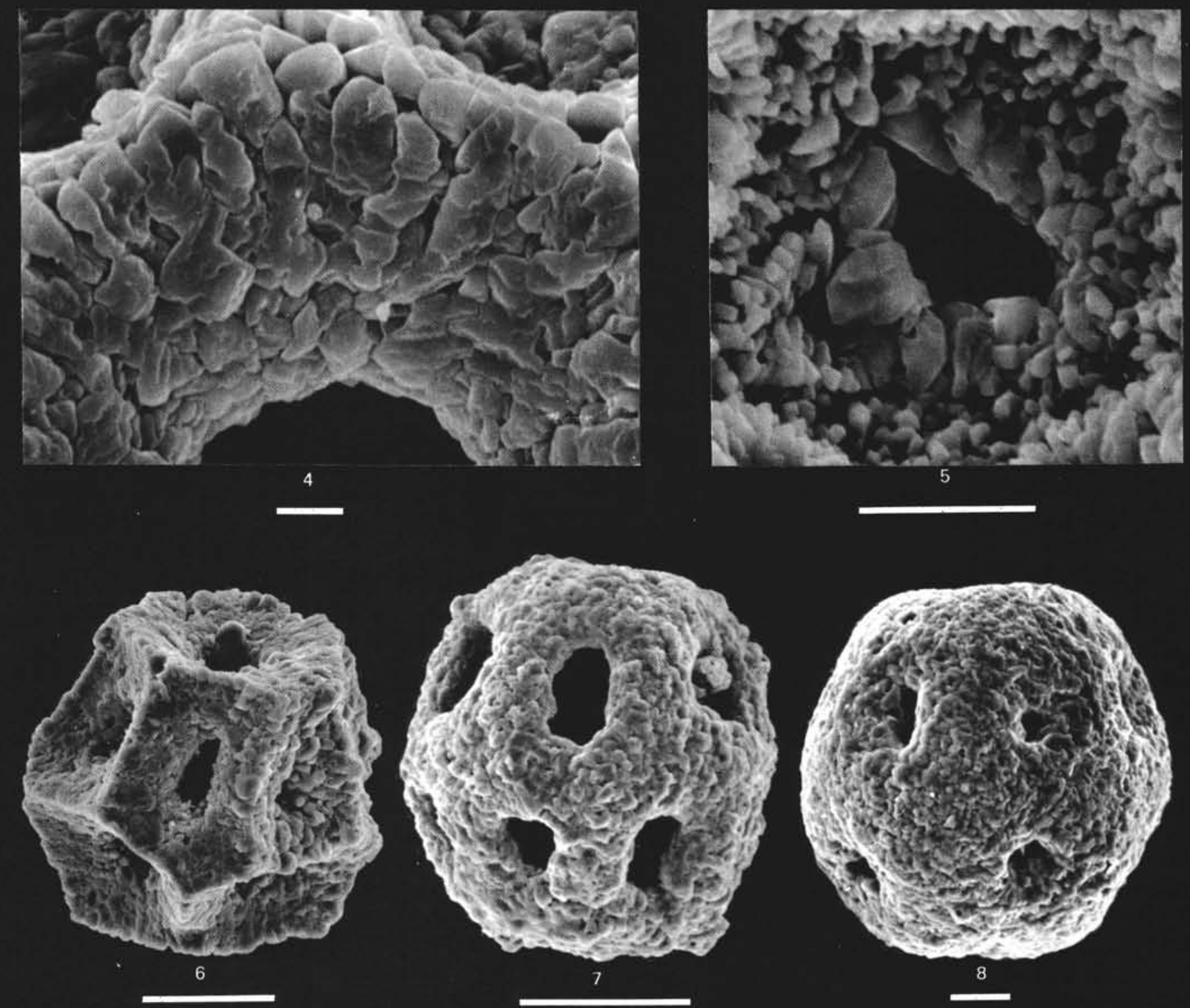